\title{
RESOLVING SPACE-TIME STRAIN PATHS OF THE PANAMINT AND COTTONWOOD MOUNTAINS, EASTERN CALIFORNIA, THROUGH BEDROCK THERMOCHRONOLOGY AND DETRITAL GEOCHRONOLOGY
}

A Thesis
presented to
the Faculty of the Graduate School
at the University of Missouri-Columbia
In Partial Fulfillment
of the Requirements for the Degree
Master of Science
BEGUM KURTOGLU
by

Dr. Tandis Bidgoli, Thesis Supervisor

JULY 2020 
The undersigned, appointed by the dean of the Graduate School, has examined the thesis entitled

\section{RESOLVING SPACE-TIME STRAIN PATHS OF THE PANAMINT AND COTTONWOOD MOUNTAINS, EASTERN CALIFORNIA, THROUGH BEDROCK THERMOCHRONOLOGY AND DETRITAL GEOCHRONOLOGY}

Presented by Begum Kurtoglu

A candidate for the degree of Master of Science, and hereby certify that, in their opinion, it is worthy of acceptance.

Assistant Professor Tandis Bidgoli

Professor Francisco Gomez

Associate Professor Mark Palmer 


\section{ACKNOWLEDGMENTS}

Completion of this project would have not been possible without the funding provided by the Department of Geological Sciences. University of Missouri, through John and Betty Marshall Opportunities of Excellence Fund and M. Ray Thomasson Named Grant from the American Association of Petroleum Geologists Foundation.

I would like to express profound respect and appreciation to my advisor, Tandis Bidgoli, for her unending support and invaluable guidance in all phases of my research and completion of this thesis. You are one of the strongest women I have ever known, and you have been an amazing role model. It has been such a privilege to work with you for the last two years and I have learned so much from you. I am also grateful to my committee members, Francisco Gomez, and Mark Palmer for their time and their thoughtful feedback on my research.

I would like to acknowledge several people who were so nice and patient while assisting me with my analyses. They include Daniel Stockli, Lisa Stockli and Rudra Chatterjee at the (U-Th)/He and U-Pb Geo-Thermochronometry Lab at University of Texas

at Austin; Doug Walker and Joe Andrew at the Isotope Geochemistry Lab at the University of Kansas (KU). I am also thankful to Daniel Shi at Mizzou, who sacrificed his spring break to help me with processing samples at KU; Tyler Cantrell, who trained Daniel and I on rock crushing and mineral separation; and my friend, Clay Campbell, for his assistance and hospitality while at KU. 
I would like to express my appreciation to Demir Altiner and Sevinc Altiner at Middle East Technical University who have inspired me and encouraged me to pursue graduate study. I also appreciate friendship and support from all the graduate students in the Department of Geological Sciences, University of Missouri, who have helped me in many ways.

I am grateful to Michael Gunnels for his love, support, and care. Finally, I would like to express my utmost gratitude and love to my parents. Ustun Kurtoglu and Sevil Kurtoglu, who always support every decision I make; share all of my stress, sadness, and hopelessness when things get hard; and remind me that everything is going to be okay; Basak Stookey and Burcu Yilmaz for being amazing sisters and role models in every possible way; to Scott Stookey for being the coolest brother-in-law and spending hours in front of a computer to help me with my cross-sections; and to my beautiful niece Hare Yilmaz and my little nephew Evren Stookey who bring so much joy to my life. 


\section{TABLE OF CONTENTS}

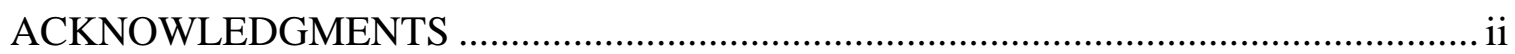

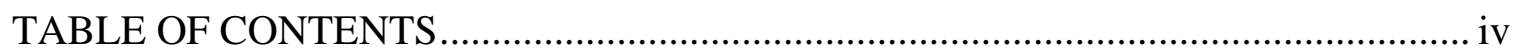

LIST OF FIGURES …................................................................................. vi

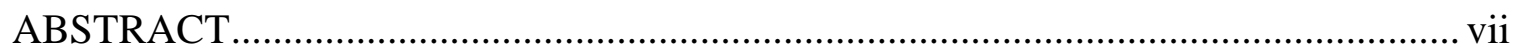

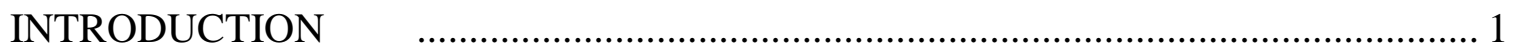

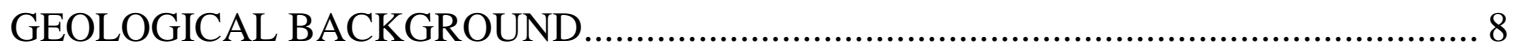

Triassic to Cretaceous Contraction and Magmatism .............................................. 8

Miocene to Pliocene Deformation ................................................................ 11

Pliocene to Recent Deformation .......................................................................... 13

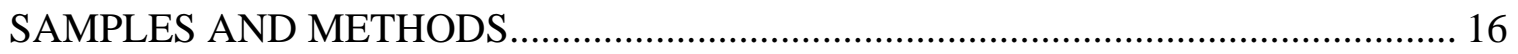

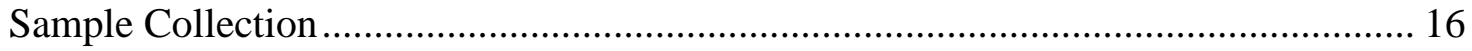

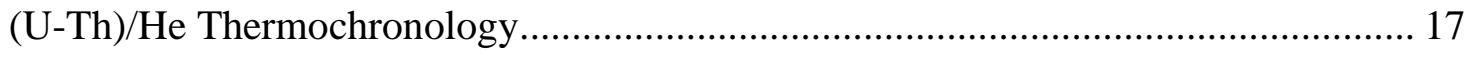

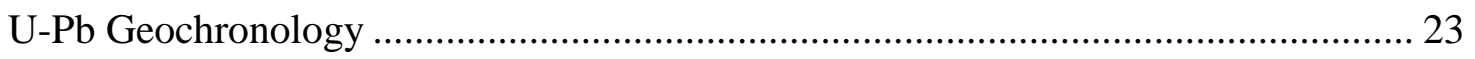

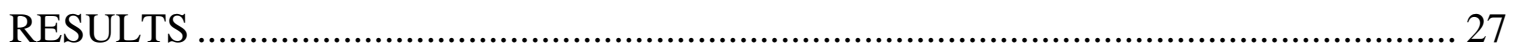

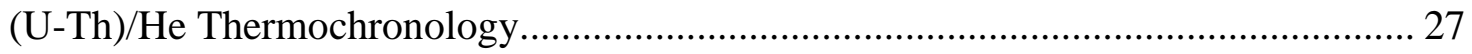

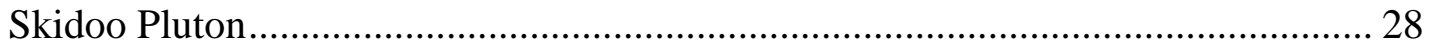

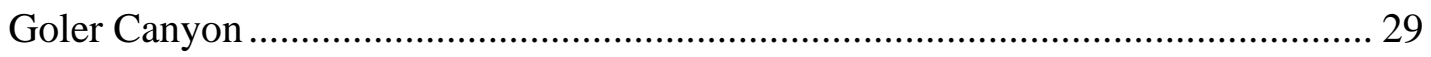


Panamint Range Sites

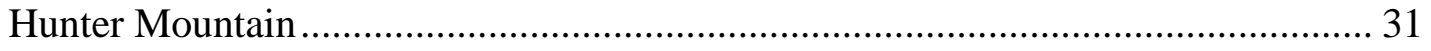

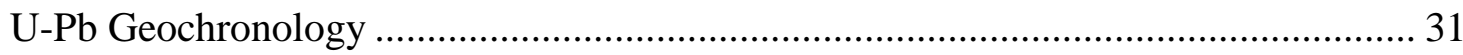

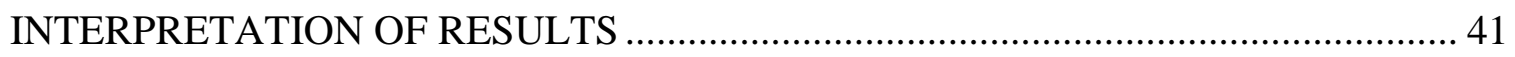

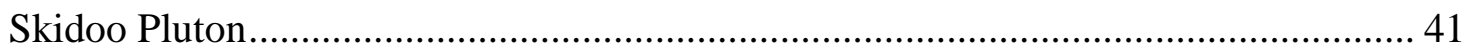

Paleodepth Reconstructions .................................................................................. 41

Vertical Exhumation and Magnitude of Extension.................................................... 42

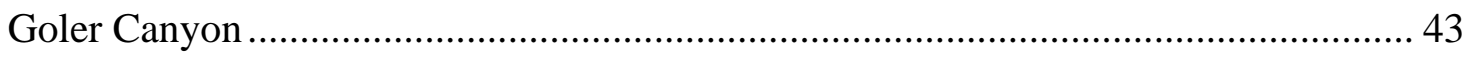

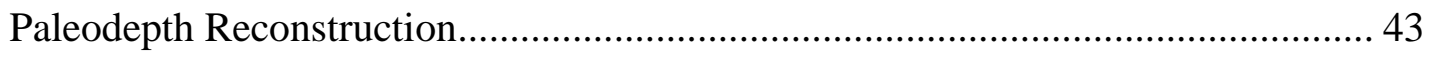

Vertical Exhumation and Magnitude of Extension..................................................... 44

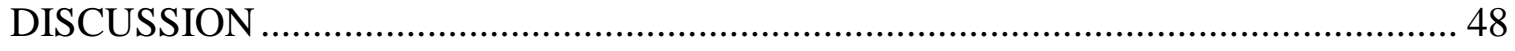

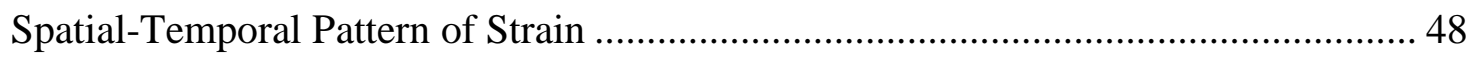

Along-Strike Variability in Extension Magnitudes ................................................... 50

Implications for Published Palinspastic Restorations ............................................... 51

Cretaceous to Latest Pliocene Fault Evolution ............................................................. 53

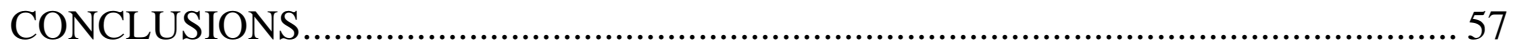

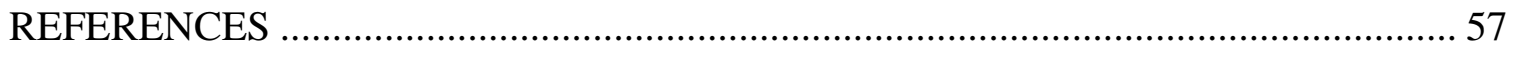

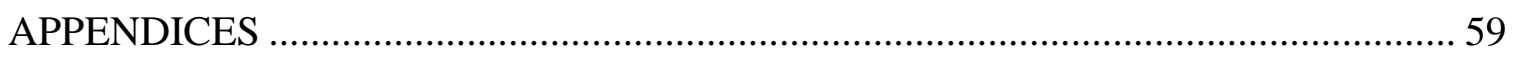




\section{LIST OF FIGURES}

Figure 1. Shaded relief map of the California and western Nevada. ............................. 4

Figure 2. Published palinspastic reconstructions for ranges west of Death Valley ........... 5

Figure 3. DEM map of the greater Death Valley region............................................ 6

Figure 4. Simplified geologic map of the Death Valley region .................................... 7

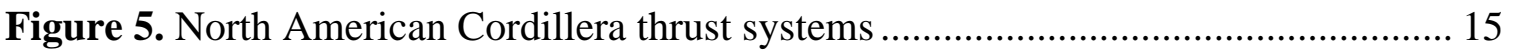

Figure 6. Schematic diagram of helium partial retention zones .................................. 26

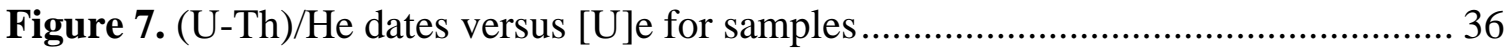

Figure 8. (U-Th)/He dates versus mass for samples ............................................... 37

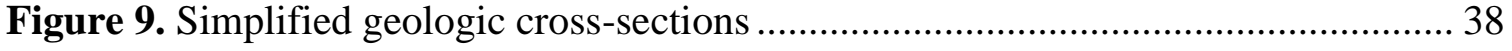

Figure 10. (U-Th)/He age versus elevation for samples. .......................................... 39

Figure 11. Kernel density estimation plots of the detrital zircon $\mathrm{U}-\mathrm{Pb}$ ages .................. 40

Figure 12. Paleodepth reconstruction of the Skidoo Pluton samples............................ 46

Figure 13. Paleodepth reconstruction from the Goler Canyon samples. ....................... 47

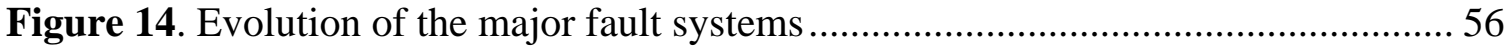




\begin{abstract}
The landscape in Death Valley region is the result of a complex history that includes Miocene Basin and Range extension and Miocene to recent transtension. Despite being one of the best studied regions in the world, reconstructing the displacement histories of faultbounded ranges has been a challenge due to difficulty in identifying reliable strain markers and timing constraints. Many of the palinspastic reconstructions produced rely on the strain markers much older than Cenozoic extensional and transtensional faults, and whose restored positions are not well-resolved. Here we present new (U-Th)/He thermochronology data from the Panamint Range and Cottonwood Mountains, west of Death Valley. The data are used to evaluate the timing, magnitude, and spatial pattern of strain associated with the faults in these ranges. We also present new detrital zircon U-Pb data from the Nova basin, in the northern Panamint, which provide additional constraints on the timing of fault motion.
\end{abstract}

The new thermochronology data comes from 36 samples collected from transects and sites in the ranges. In the northern part of the Panamint Range, apatite He (AHe) ages from a transect across the Skidoo pluton, in the footwall of the Panamint-Emigrant detachment (PED), show continuous exhumation from 8-4 Ma. Zircon He (ZHe) data from the same transect preserve a zircon He partial retention zone (PRZ). In the southern part of the range, AHe ages from Goler Canyon record rapid exhumation at $4 \mathrm{Ma}$ and an AHe PRZ. ZHe data from this transect also record cooling between 80-50 Ma, similar to AHe and $\mathrm{ZHe}$ ages from a transect in the Cottonwood Mountains. 
Paleodepth reconstructions of samples from the Panamint Range suggest that the northern part of the range experienced 4.2-7.2 of vertical exhumation, compared to only 1.9-2.4 $\mathrm{km}$ of exhumation in the southern part of the range. This difference in magnitudes is also reflected in the fault timing data, which indicate that middle to late Miocene exhumation was concentrated in the northern part of the range. Although both parts of the range see $\sim 4$ Ma exhumation, apatite ages from two key sites, near the intersections of the Manly Pass and Hunter Mountain faults with the PED, record younger cooling at 2.8-2.6 Ma. These latest Pliocene ages are similar to AHe ages from the Inyo Mountains $(2.8 \pm 0.7$ Ma; Lee et al., 2009) that have been interpreted as reflecting the timing of initiation of the Hunter Mountain fault.

Together, the new and the published data show a complex history, with multiple episodes of deformation, beginning in the Late Cretaceous and continuing through the latest Pliocene. The data also suggest that the transition from the Basin and Range extension to the dextral transtension may have initiated at $\sim 4 \mathrm{Ma}$, but the full integration of this system of faults may not have occurred until the latest Pliocene. 


\section{INTRODUCTION}

The Eastern California shear zone (ECSZ) and the Basin and Range extensional province, together, define a broad and complicated zone of intraplate deformation (Dokka and Travis, 1990; Burchfiel et al., 1992, Wernicke, 1992; Fig. 1). These two deformation zones converge in the Death Valley region, one of the best studied structural and magmatic provinces in the world (Fig. 1). The region has been a critical area for examining the processes of continental extension and diffuse plate boundary strain, and the preextensional structural and the thermal properties that led to large-scale Cenozoic extension and more recent transtension of the western United States. The connection between the extension and dextral shear within this region is hypothesized to be a result of both kinematic changes that took place at the Pacific-North American plate boundary (Atwater, 1970; Dokka and Travis, 1990; Atwater and Stock, 1998) and intraplate geodynamic factors (Jones et al., 2004; Oldow et al.,2008; Le Pourhiet et al., 2006; Saleeby et al., 2012; Bidgoli et al., 2015). However, the details of the transition from Basin and Range extension to ECSZ dextral transition for many individual ranges in the Death Valley region remain unresolved.

Palinspastic restorations of deformation in the Death Valley region have been key to

developing deformation models and for understanding underlying causes. Although a number of field-based studies have been completed in the region, published displacement vectors for individual ranges are variable and suggest that strain paths are not well resolved (Fig. 2). As shown in Figure 2, there are large discrepancies between published 
reconstructions (e.g., Snow and Wernicke, 1989, 2000; Serpa and Pavlis, 1996; McQuarrie and Wernicke, 2005, Andrew and Walker, 2009). For example, Snow and Wernicke (2000) documented $52.5 \mathrm{~km}$ of northwest displacement of the Argus Range relative to the Panamint Range based principally on the separation of the Paleozoic and Mesozoic thrusts by younger structures. Their vector was significantly larger than the reconstructions by McQuarrie and Wernicke (2005) of $31 \mathrm{~km}$ northwest and by Serpa and Pavlis (1996) of 23 km northwest (Fig. 2). Thermochronology data from the central Panamint Range indicate $8.4 \mathrm{~km}$ vertical exhumation in the footwall of the Panamint-Emigrant detachment (PED), the major fault in the western part of range (Bidgoli et al., 2015), and imply much lower displacements of $10-15 \mathrm{~km}$, depending on the fault's dip. Similar challenges exist for reconstructions of the Cottonwood Mountains relative to the Panamint Range and for the Argus Range relative to the Slate Range (Fig. 2). Differences between these results may be a consequence of the age of the structures or features being used in the restorations. As pointed out in Andrew and Walker (2009), reconstructions with larger displacements use mostly Mesozoic markers, while those with smaller displacement rely mainly on Cenozoic markers.

Another difficulty in reconstructing the Miocene to Pliocene motion of these ranges is determining the role of earlier pulses of the deformation. The discrepancies in the abovementioned displacement magnitudes may relate to Late Cretaceous to Eocene extensional deformation. This deformation is documented in the Funeral Mountains (Applegate et al., 1992; Applegate and Hodges, 1995), west of the study area, and elsewhere in the region (Wells and Hoisch, 2008; Glazner et al., 2005; Bartley et al., 2007; Wood and Saleeby, 1997; Chapman et al., 2012). It has also been documented by thermochronology studies in 
the White, Inyo, and Argus ranges (Stockli et al, 2002; Lee et al., 2009; Bidgoli, 2014) (Fig. 3). Late Cretaceous to Eocene exhumation has also been documented in the footwalls of Panamint-Emigrant detachment system, in the central Panamint Range, and Slate Range detachment, in the central and southern Slate Range (Walker et al., 2014; Bidgoli et al., 2015) (Fig. 3). Thus, a portion of the strain being accounted for in some models (e.g., Snow and Wernicke, 2000) may be older.

In this study, we use new apatite and zircon (U-Th)/He thermochronologic data (Fig. 4) and detrital zircon $\mathrm{U}-\mathrm{Pb}$ geochronologic data to reconstruct the timing, magnitude, and spatial pattern of strain in the Panamint Range and Cottonwood Mountains, west of Death Valley. These ranges and their faults are important because they have accommodated a significant portion of the Miocene to Pliocene plate boundary strain. The thermochronology data are evaluated using new geologic cross-sections and published fault timing data from the region. The data and analyses are used to test two specific hypotheses: (1) that the timing of the transition from Basin and Range extension to dextral transtension occurs at $\sim 4 \mathrm{Ma}$, similar to other published data from the Death Valley region and (2) that published palinspastic reconstructions do not account for Late Cretaceous to Eocene extension in the region and are thus, too large. In addition to providing new constraints on the evolution of faults since the Cretaceous, the results provide an independent check on published restorations of Miocene to recent deformation. 


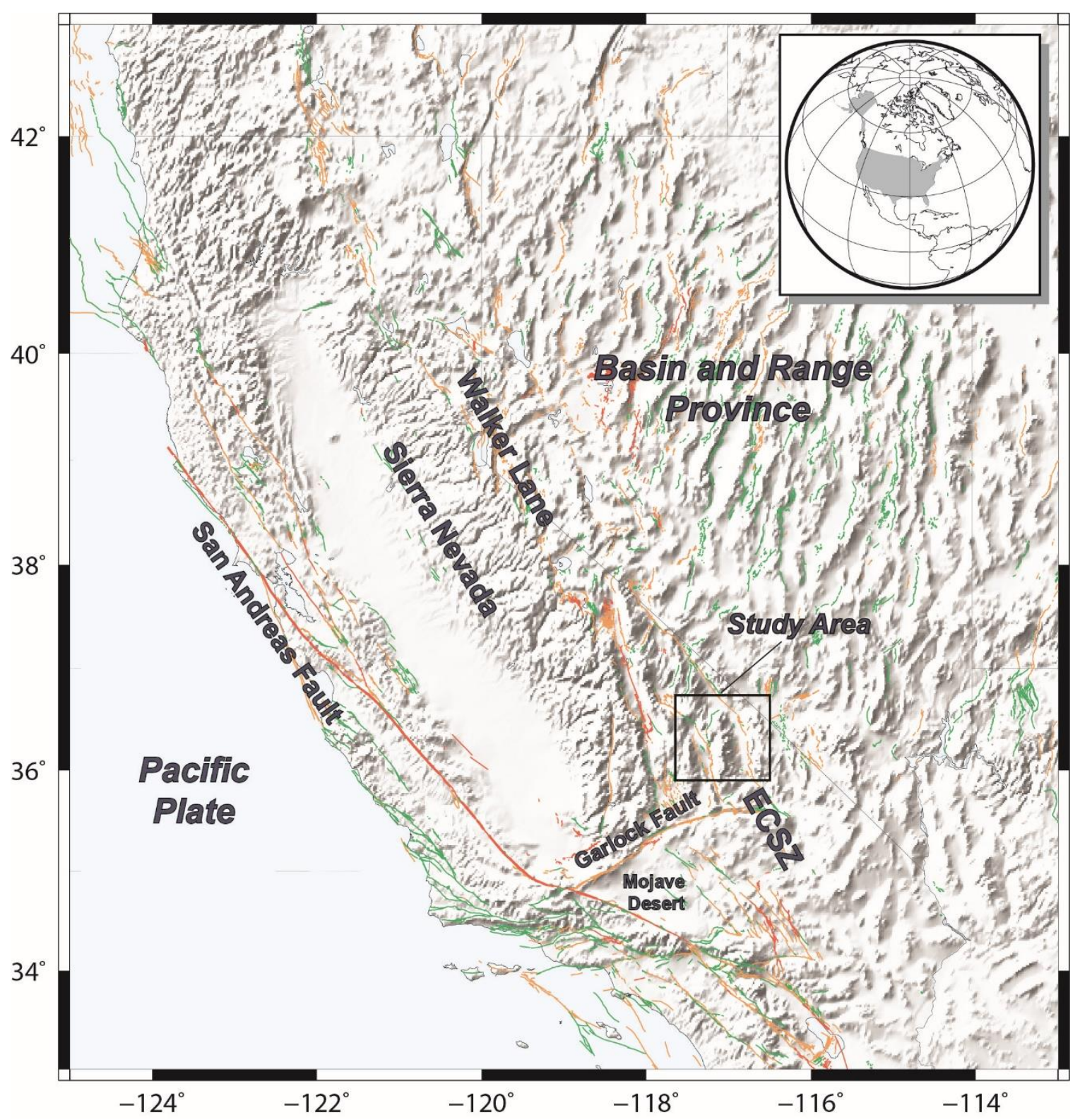

Figure 1. Shaded relief map of the California and western Nevada showing the major faults, tectonic provinces, and the location of the study area (black box). Red: historic faults ( $<150$ years), orange: latest Quaternary faults (<15,000 years), green: late Quaternary faults $(<130,000$ years) (From USGS Data Base, U.S. Quaternary Faults). Map data from Wessel et al.(2013) and USGS U.S. Quaternary Faults Database. ECSZ - Eastern California shear zone. 


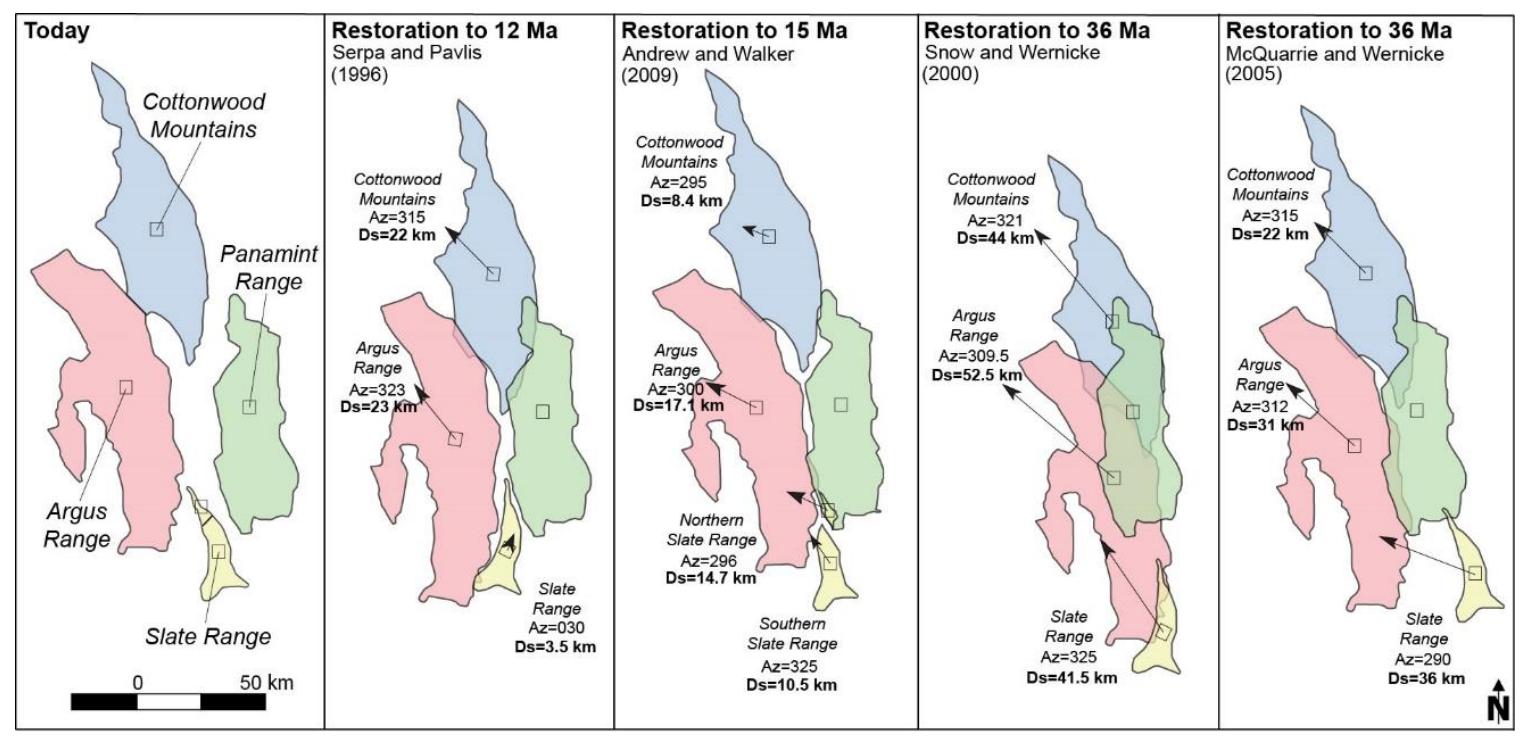

Figure 2. Published palinspastic reconstructions for ranges west of Death Valley and their associated displacement vectors. The arrows indicate the displacement magnitude ((Ds: distance) and direction (Az: azimuth) of each square with respect to the Panamint Range (modified from Andrew and Walker, 2009). 


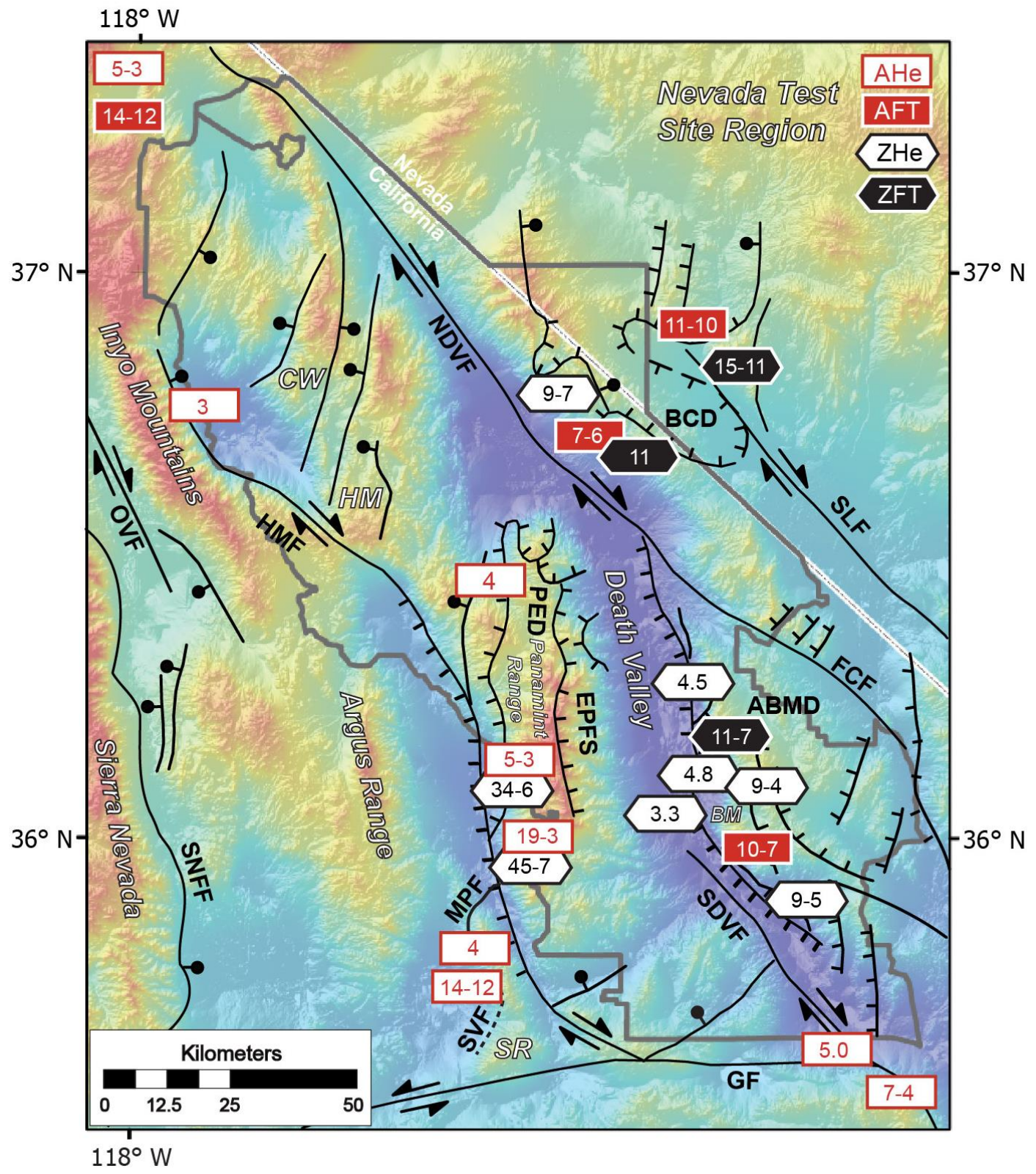

Figure 3. DEM map of the greater Death Valley region with major detachment faults (hachures), high-angle normal faults (ball and stick), and strike-slip faults (relative motion arrows). Published Miocene to Pliocene low-temperature thermochronology ages are also shown. Faults after Wernicke et al. (1988). ABMD Amargosa-Black Mountain detachment; BCD - Boundary Canyon detachment; EPFS - Eastern Panamint fault system; FCF - Furnace Creek fault; GF - Garlock Fault; HMF - Hunter Mountain fault; MPF - Manly Pass fault; OVF - Owens Valley fault; PED - Panamint-Emigrant detachment; SDVF - Southern Death Valley fault; SHF - Sheephead fault; SNFF - Sierra Nevada Frontal fault; SLF - State Line fault; SVF Searles Valley fault; TMD - Tucki Mountain detachment. Warm colors represent the mountain ranges and cool colors are the basins. Avawatz Mountains-Reinert et al. (2003), Bidgoli et al., 2015; Black Mountains-Holm et al. (1992), Holm and Dokka (1993), Bidgoli et al., 2015; Bare Mountain and Bullfrog Hills-Ferrill et al. (2012); Funeral Mountains-Holm and Dokka (1991), Hoisch and Simpson (1993); Panamint Range-Bidgoli et al., 2015; Slate Range-Walker et al. (2014); Inyo Mountains-Lee et al. (2009); White Mountains-Stockli et al. (2003). 


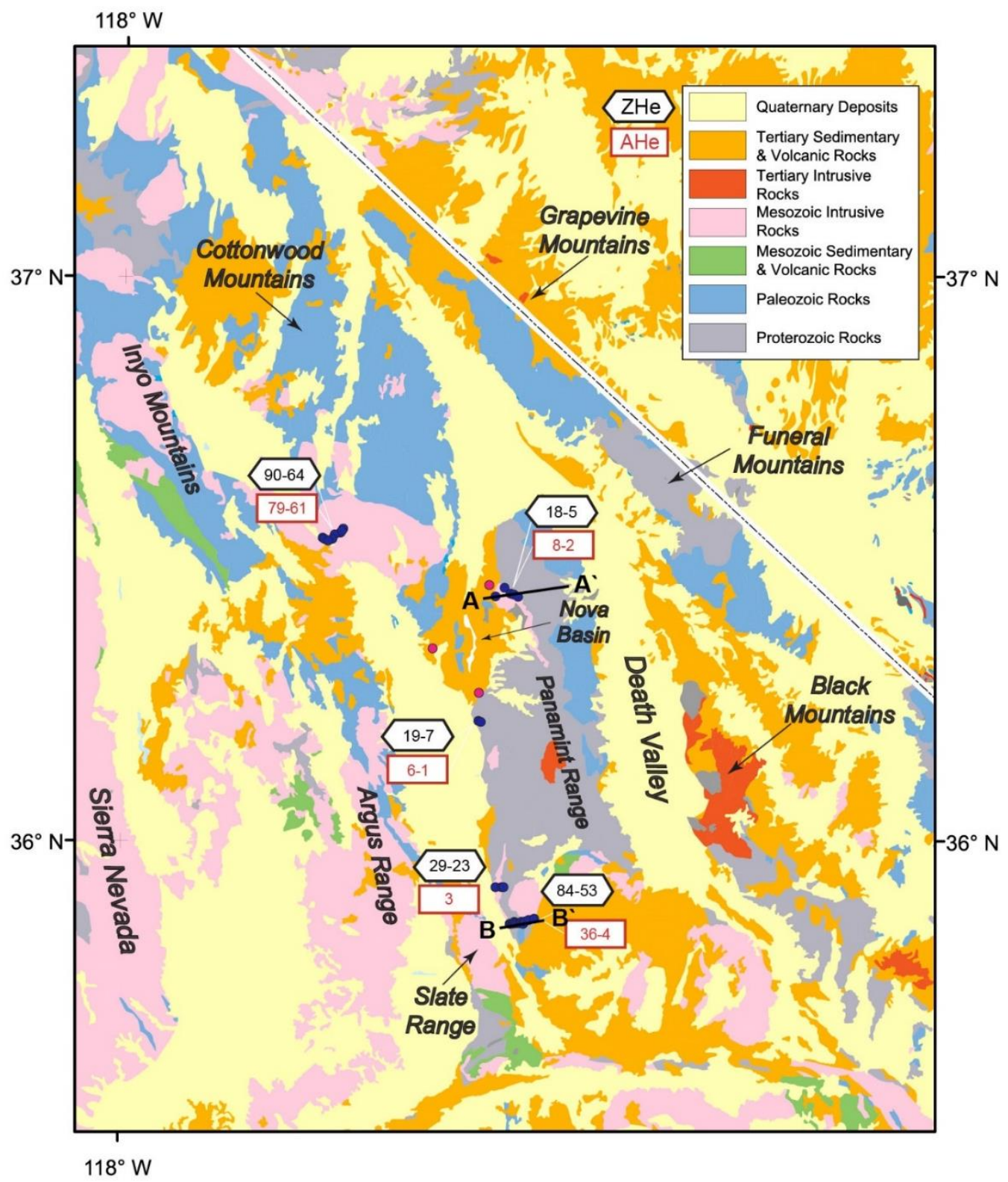

Figure 4. Simplified geologic map of the Death Valley region with thermochronology samples (blue circles) and geochronology samples (red circles) from this study. New zircon and apatite (U-Th)/He age ranges are shown. Map data from compilation by Ludington et al. (2005) 


\section{GEOLOGICAL BACKGROUND}

The present configuration and morphology of the ranges and valleys in the Death Valley region are the result of a complex tectonic history that involves multiple episodes of deformation. Mesozoic structures and plutons formed during three main episodes and are overprinted by at least two periods of the Miocene to Pliocene deformation that are distinct, but time transgressive (e.g. Bidgoli et al., 2015). In the first period ( 18 to $5 \mathrm{Ma}$ ), large magnitude east-west extension was accomplished by a series of low- and high-angle normal faults (e.g. Moore, 1976; Smith et al., 1968; Snow and Wernicke, 2000; Walker et al., 2005; Numelin et al., 2007). During the second period ( 10 Ma to 2.5 Ma), dextral transtension, accomplished by a mixture of normal and strike-slip faults of the ECSZ,

dominated (Dokka and Travis, 1990; Reheis and Dixon, 1996; Henry et al., 2007; Lee et al., 2009). In the following sections, we briefly outline this tectonic history and the major structures involved.

\section{Triassic to Cretaceous Contraction and Magmatism}

The Death Valley region contains structures that developed during Mesozoic contraction and extension. Contractional structures are visible in the study area (Wernicke et al., 1988) and in many of the surrounding ranges (McAllister, 1971; Reynolds, 1974; Burchfiel et al., 1983) (Fig. 5). The structures and associated metamorphism formed during three main periods: (1) Permian to early Triassic deformation is associated with southeastvergent folds and thrusts of the Death Valley thrust belt (Gulliver, 1976; Snow and Wernicke, 1989; Snow, 1992; Swanson, 1996; Renik and Christie-Blick, 2013); (2) Late 
Triassic to Early Cretaceous deformation is associated with the East Sierra thrust system, a belt of northwest-vergent folds and thrusts (Smith et al., 1968; Walker et al., 1990; Dunne and Walker, 1993; Stevens et al., 1997; Coleman et al., 2003; Dunne and Walker, 2004); and (3) Late Jurassic burial and metamorphism is related to the east-vergent Sevier thrust belt (Wrucke et al., 1995; Andrew, 2002; Dunne and Walker, 2004) (Fig. 5).

In the Panamint Range, contractional structures include the Panamint, Goldbug, and Butte Valley thrusts. The Panamint thrust, mapped in the northern part of the range in the Tucki Mountain area, juxtaposes late Precambrian sedimentary and metasedimentary units (Johnnie Formation) in its hanging wall against lower Cambrian quartzite, middle Ordovician quartzite and early Carboniferous shale in the footwall. The timing of fault motion is not well established for the Panamint thrust, but the fault is inferred to correlate to other structures of the Permian to early Triassic Death Valley thrust belt (Snow and Wernicke, 1989; Snow and Wernicke, 2000; Renik and Christie-Blick, 2013). In the southern part of the range, the Goldbug and Butte Valley thrusts are mapped. The Goldbug thrust juxtaposes Jurassic hornblende diorite in the hanging wall against Precambrian rocks in the footwall, whereas the Butte Valley fault juxtaposes the Neoproterozoic rocks and Mesozoic plutonic rocks in the hanging wall against Paleozoic to Mesozoic rocks in its footwall of the fault. Timing of these structures is not well established; however, the Butte Valley thrust formed before the intrusion of the plutons that are late Jurassic and early Cretaceous in age and after the accumulation of the Jurassic metavolcanic rocks, suggesting the age of the fault is middle or late Jurassic (Wrucke et al., 1995). These timing relations suggest the Butte Valley thrust is likely part of the East Sierra thrust system. However, the northern part of the Butte Valley thrust cuts an $\sim 13$ Ma dike and is truncated by the $\sim 145$ 
Ma Manly Peak pluton, indicating that the fault has been reactivated since the Miocene (Andrew and Walker, 2009).

Magmatism in the Death Valley region also occurred during middle to late Mesozoic contraction. In the Panamint and Cottonwood Mountains major volcanic centers formed during the Jurassic and Late Cretaceous. From oldest to youngest, these include the $\sim 174$ Ma Hunter Mountain batholith in the southern Cottonwood Mountains (Chen and Moore, 1982), the 145 Ma Manly Peak pluton in the southern Panamint Range (Andrew, 2002; Ramo et al., 2002), and the 100 Ma Skidoo and 66-70 Ma Hall Canyon plutons in the northern part of the Panamint Range (Knapp et al., 1983; Labotka et al., 1985; Hodges et al., 1990). The positions of these intrusion have played a critical role in the various palinspastic reconstruction models. For instance, both Snow and Wernicke (2000) and McQuarrie and Wernicke (2005) have tied rocks in the Argus Range to exposures of the pluton of the southern Panamint Range.

Although most of the Mesozoic deformation was contractional, there is also evidence of Late Cretaceous to Eocene extension. Extensional structures and unroofing at 70 Ma have been documented in the Funeral Mountains by Applegate et al. (1992) and Applegate and Hodges (1995). This phase of deformation has also been documented in by thermochronology studies across the region (e.g., Lee et al., 2009; Bidgoli, 2014, Walker et al., 2014) and may relate to a similar phase of synconvergent extension documented in the northern Basin and Range in Nevada, Utah, and Idaho and across the Mojave (Figure 5; Wells and Hoish, 2008 and references therein).

In the Panamint Range, the Harrisburg fault, one of the major faults of the Tucki Mountain detachment system, is mapped in the northern part of the range (Wernicke et al., 
1986, 1988; Hodges et al., 1987, 1990). The fault, which is back tilted eastward across the range, juxtaposes the Noonday Formation in the hanging wall against the upper Kingston Peak Formation in the footwall. It is important to note that the footwall of the fault is ductilely deformed, whereas other normal faults in the Tucki Detachment system and region are brittle structures. The fault's timing is not well established; it's motion postdates the 100 Ma Skidoo pluton but predate intrusion of the 10.6 Ma Little Chief Stock (McKenna and Hodges, 1990; Hodges et al., 1990).

\section{Miocene to Pliocene Deformation}

The Death Valley area has been the site of extension since at least middle Miocene time (Cemen et al., 1982). Large magnitude Miocene extension was mainly accomplished by low-angle normal faults in the region, including the Armargosa-Black Mountains and Panamint-Emigrant detachment systems, and East Panamint fault system (Wright et al., 1974; McKenna and Hodges, 1990). These faults are responsible for the separation and development of the discrete crustal blocks that make up the ranges today.

The Amargosa-Black Mountains detachment is a low-angle normal fault exposed in the Black Mountains, west of Death Valley (Wright et al., 1974). This fault was defined by Noble (1941) as the contact between the Paleoproterozoic basement gneiss and the Neoproterozoic sedimentary rocks in the southern Black Mountains. In the northern part of the range, the fault separates Cenozic volcanic and sedimentary rocks in the hanging wall from Proterozic gneiss and Miocene diorite and granite intrusions in the footwall. Timing data from the southern Black Mountains suggest cooling beginning at $12 \mathrm{Ma}$ along the fault system (Holm et al., 1992). 
The Panamint Range is considered the hanging wall of the Amargosa-Black Mountains detachment. Major Cenozoic structures in the Panamint Range include: (1) the Eastern Panamint fault system in the eastern part of the range (McKenna and Hodges, 1990; Hodges et al., 1990) and (2) the PED in the western part of the range (Cichanski, 2000; Kirby et al., 2004; Walker et al., 2005). Together these faults exhume the core of the range, made of 1.7 Ga quartzofeldspathic gneiss (Silver et al., 1961), middle and late Precambrian biotite and hornblende schist and quartzite (Labotka et al., 1980), and Cretaceous to Cenozoic granitoids (Knapp et al., 1983; Labotka et al., 1985; Hodges et al., 1990). The PED is made up by Emigrant and Towne Pass faults, in the northern part of the range, and the Panamint detachment, in the central and southern parts of the range. It is important to note the Miocene PED has been interpreted to continue to the south and link with a similar low-angle normal fault in the Slate Range, the Slate Range Detachment (Andrew and Walker, 2009).

Timing data for faults in the Panamint Range come from a Miocene pluton and volcanic units on the east side of the range and from a basin succession on the west side of the range. The Eastern Panamint fault's timing is not known, but it is inferred to postdate the 10.6 Ma Little Chief Stock and an east-tilted succession of volcanic rocks of the east side of the range, the ca. 10.5 to 9.4 Ma Trail Canyon volcanic sequence (McKenna and Hodges, 1990; Hodges et al., 1990). For the PED, fault motion is constrained by the Nova Formation, a $\sim 3 \mathrm{~km}$ thick basin preserved in the hanging wall of the Emigrant fault (Snyder et al., 1989; Snyder and Hodges, 2000). The Nova basin is made up of three major basinfilling successions: (1) the lower Nova Formation, which consists of coarse and poorly bedded conglomerates with megabreccia deposits and volcanic flows; (2) the middle Nova 
Formation, which includes conglomerates that are appear similar to the lower part of sucession, but that have a mixed provenance ; and (3) the upper Nova Formation, which is made up of well-bedded conglomerates reworked from the middle and lower parts of the succession, and lacks volcanic units (Hodges et al., 1989). Although basin development is

thought to have initiated after ca. $12 \mathrm{Ma},{ }^{40} \mathrm{Ar} /{ }^{39} \mathrm{Ar}$ geochronology data from intervening volcanic units indicate rapid deposition from ca. 4.4 and 3.0 Ma (Snyder et al., 1989; Snyder and Hodges, 2000).

\section{Pliocene to Recent Deformation}

Pliocene to recent deformation in the study region is mainly transtensional and driven by the Panamint Valley, Hunter Mountain, Searles Valley, and Manly Pass faults (Burchfiel et al., 1987; Wernicke et al., 1988; Bellier and Zoback, 1995; Wernicke and Snow, 1998; Snow and Wernicke, 2000). These faults are part of the ECSZ (Dokka and Travis, 1990a, 1990b), whose initiation is interpreted to be as old as $10 \mathrm{Ma}$ to as young as 1.5 Ma depending on location (Wernicke et al., 1988; Hodges et al., 1989; Bellier and Zoback, 1995; Wernicke and Snow, 1998; Snow and Wernicke, 2000; Monastero et al.,2002; Stockli et al., 2003; Lee et al., 2009; Walker et al., 2014; Bidgoli et al., 2015). In general, the timing data suggest faults of the ECSZ initiate earlier to the east and progressively young to the west (Walker et al., 2014; Bidgoli et al., 2015). While kinematic changes at the plate boundary are commonly cited as the cause for the transition to dextral transtension, widespread exhumation west of Death Valley at 4 Ma suggests the transition to dextral shear may be, in part, linked to lithospheric delamination of the southern Sierra Nevada (see discussion in Bidgoli et al., 2015). 
In the study area, the Panamint Valley fault zone is the main structure and represents the most recent phase of deformation on the PED. The northern Panamint Valley fault is primarily a low-angle normal with active high-angle normal faults in its hanging wall, but the southern part of the fault is steep and accommodates strike-slip motion (Walker et al., 2005). To the north, the northern Panamint Valley fault zone links with the strike-slip Hunter Mountain fault and transfers strain to the southern Saline Valley fault zone. Fault initiation for the Hunter Mountain fault is documented between 4.0 and 2.8 Ma (Burchfiel et al., 1987; Hodges et al., 1989; Lee et al., 2009). The 4.0 Ma age is based on Pliocene basalts that are offset by the fault, consistent with 4 Ma exhumation documented in the central Panamint Range (Bidgoli et al., 2015). However, zircon and apatite (U-Th)/He data from a study by Lee et al. (2009) suggest rapid uplift and exhumation of the eastern part of the Inyo Mountains at 2.8 Ma. These data were used by Lee et al. (2009) to infer the initiation of the Hunter Mountain fault zone and its linkage with the Panamint Valley system.

To the south, the Panamint Valley fault zone links with the Manly Pass fault and transfers strain to the Searles Valley fault (Maerten et al., 1999; Walker et al., 2005). The Manly Pass fault is an active, north-east striking and west-dipping normal fault (Smith et al., 1968; Moore, 1976; Walker et al., 2005) with slip that is directed to the west-northwest (Walker et al., 2005). The Searles Valley fault is an active low- to moderate-angle, northsouth-striking normal fault (Smith et al., 1968; Benson et al., 1990; Numelin and Kirby, 2004; Walker et al., 2005; Walker et al., 2014). Timing data suggest that both the Manly Pass and Searles Valley faults initiated at $\sim 4 \mathrm{Ma}$ (Walker et al., 2014). 


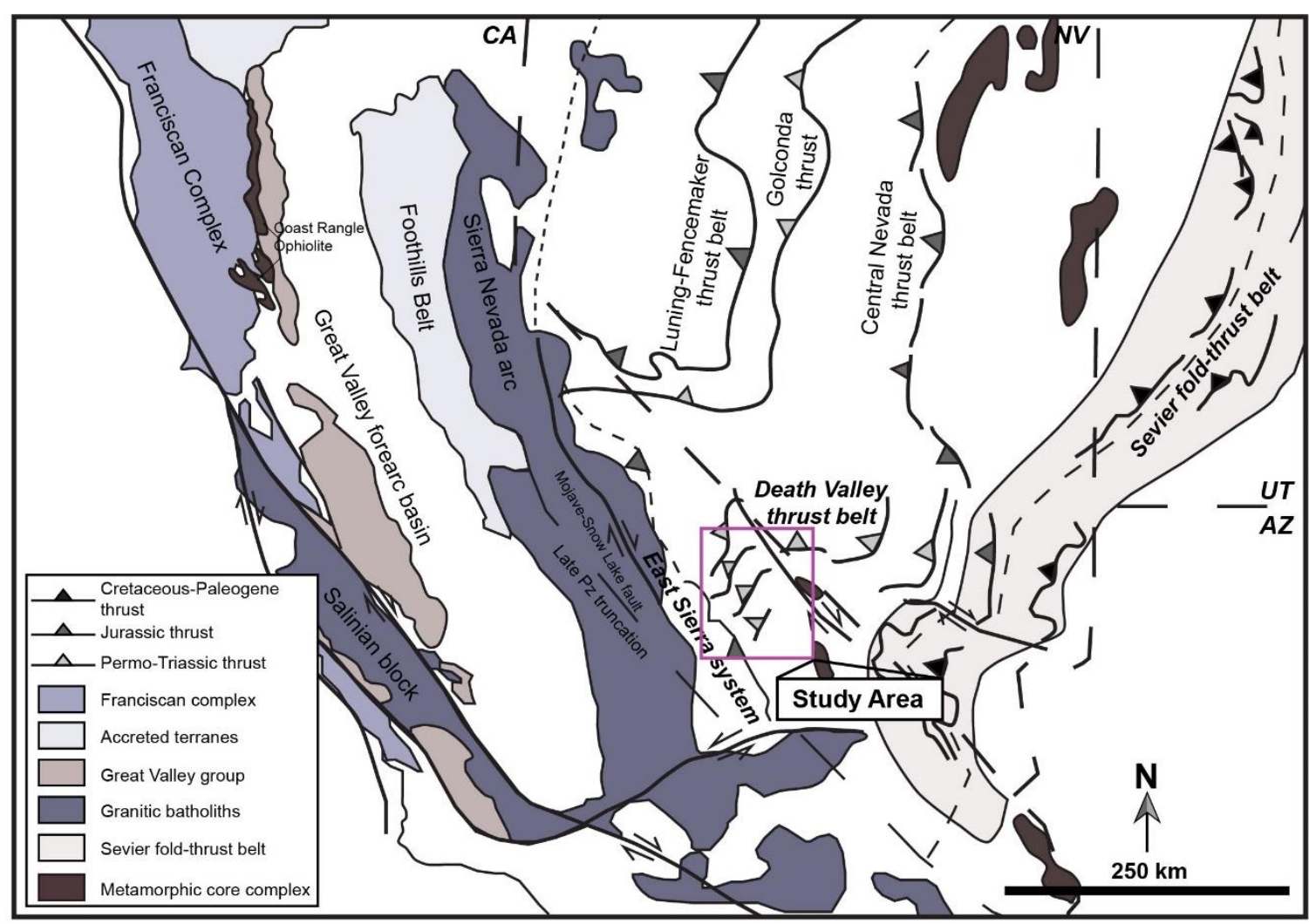

Figure 5. Simplified tectonic map of the North American Cordilleran system showing the major thrust systems and the study area. Modified from DeCelles (2004); Dunne and Walker (2004); Shervais et al. (2005); Snow and Wernicke (2000); Wyld and Wright (2001); and Giallorenzo et al. (2017). 


\section{SAMPLES AND METHODS}

\section{Sample Collection}

We obtained a total of thirty-six thermochronology and geochronology samples (3$5 \mathrm{~kg}$ each) from the study area. Samples were collected from east-west transects in the southern and northern Panamint Range and southern Cottonwood Mountains (Fig. 4). Samples were also collected from two additional sites in the central part of the Panamint Range, near the intersections with the Hunter Mountain fault zone and Manly Pass fault (Fig. 4). In the Panamint Range, samples were collected, principally, from granitoids of the Skidoo, Hall Canyon, and Manly Peak plutons in the footwall of the PED. For the Cottonwood Mountains, samples were collected Hunter Mountain batholith, north of the Hunter Mountain faults zone. With respect to sampling strategy, we tried to collect samples from the transects oriented perpendicular to the strike of major faults, following Stockli (2005).

For U-Pb geochronology, one sample was collected from each of the three major basin-filling units of the Nova Basin, which provides a record of the late Miocene to Pliocene exhumation history of the Panamint Range and surrounding region (Snyder and Hodges, 2000). The zircon U-Pb crystallization ages and their distributions were obtained for provenance and maximum depositional age analysis (e.g., Dickinson and Gehrels, 2010). These data will be incorporated into a future project focused on comparing cooling histories preserved in the exhumed footwalls of the PED with those obtained from doubledated hanging-wall sediments. 


\section{(U-Th)/He Thermochronology}

Quantification of the timing, magnitude, and rate of crustal processes is a perennial challenge in tectonics research. For extensional systems, thermochronologic methods (e.g., ${ }^{40} \mathrm{Ar} /{ }^{39} \mathrm{Ar}$, fission-track, (U-Th)/He, etc.) have played a critical role in improving our understanding of fault- and erosion-related exhumation of the upper and middle crust and even the mantle. As outlined in Stockli (2005), these methods are capable of providing constraints on a number of important parameters, including: the timing of fault initiation, duration of extensional deformation, magnitude and rate of vertical exhumation, fault slip rates, geometry of faults and fault blocks, geothermal gradients preceding or related to extension, and eroded overburben (e.g. Fitzgerald and Gleadow, 1988; Foster et al. 1990; Fitzgerald et al. 1991; John and Foster 1993; John and Howard 1995; Foster et al., 1993; Ketcham, 1996; Foster and John, 1999: Wells et al., 2000; Axen et al. 2001; Stockli et al. 2001, 2002, 2003; Reiners and Brandon, 2006; Tian et al., 2012; Guenthner et al., 2015).

Part of the success of these techniques for extensional systems is that normal faults provide one of the simplest mechanisms for exhuming rocks from deeper crustal or even mantle depths. Both low- and high-angle normal faults show very different amounts of exhumation between hanging wall and footwall blocks. Thermochronologic methods allow for the investigation of these differences, reflected in the low-temperature cooling history of a rocks in the footwalls of normal faults (e.g., Fitzgerald et al., 1986; Foster and John, 1999; Miller et al., 1999; Ehlers and Chapman, 1999; Ehlers et al., 2001; Stockli et al., 2001, 2002, Curry et al., 2016; Wolff et al., 2020). However, these methods can be used only when the magnitude of exhumation is large enough to exhume and cool rocks that were at depth to shallower levels, moving them to thermal conditions below the closure 
temperature (Dodson, 1973) of the minerals and radiometric system of interest. Of the available thermochronometric techniques (e.g., ${ }^{40} \mathrm{Ar} /{ }^{39} \mathrm{Ar}$, fission-track, etc.), the (UTh)/He method is frequently applied to extensional systems, in part because of the low closure temperatures of the commonly used minerals, specifically zircon and apatite (e.g. Stockli et al., 2000; Ehlers et al., 2005, Stockli, 2005; Lee et al., 2009; Evans et al., 2015).

In this study, we use zircon and apatite (U-Th)/He thermochronometry. The (U$\mathrm{Th}) / \mathrm{He}$ method is based on the production of ${ }^{4} \mathrm{He}$ (alpha particles) from three primary radioactive decays: ${ }^{235} \mathrm{U},{ }^{238} \mathrm{U}$, and ${ }^{232}$. The production of ${ }^{4} \mathrm{He}$ follows:

$$
{ }^{4} H e=8^{238} U\left[\exp \left(\lambda_{238 t}\right)-1\right]+7^{235} U\left[\exp \left(\lambda_{235 t}\right)-1\right]+6^{232} T h\left[\exp \left(\lambda_{232 t}\right)-1\right]
$$

where ${ }^{4} \mathrm{He},{ }^{235} \mathrm{U},{ }^{238} \mathrm{U}$ and ${ }^{232} \mathrm{Th}$ are the present-day atoms, $\lambda$ is the relevant decay constant and $\mathrm{t}$ is the accumulation time (Farley, 2002; Reiners, 2002). However, once generated, ${ }^{4} \mathrm{He}$ retention in minerals is temperature dependent (Harrison and Zeitler, 2005). Other influential parameters on ${ }^{4} \mathrm{He}$ retention include mineralogy, cooling rate, grain size, and crystal lattice damage (Dodson, 1973; Farley, 2000; Reiners and Farley, 2001; Shuster et al., 2006).

Apatite is frequently used as a (U-Th)/He thermochronometer because it records cooling at low temperatures. ${ }^{4} \mathrm{He}$, generated during decay, is mostly retained below $\sim 40{ }^{\circ} \mathrm{C}$ but completely lost above $\sim 80{ }^{\circ} \mathrm{C}$ by volume diffusion (Wolf et al., 1996, 1998; House et al., 1999; Stockli et al., 2000). As discussed in the study by Wolf et al. (1998), these temperatures define the thermal sensitivity of apatite or what has been coined as the partial retention zones (PRZ). Stockli (2002) and subsequent studies (Stockli, 2005 and references therein) have shown that these temperature windows can be used to reconstruct the 
apparent age versus paleodepth and elevation trends of exhumed low-angle fault block as shown in Fig. 6.

Zircon is also used as a (U-Th)/He thermochronometer in the extensional settings (e.g., Reiners et al., 2000; 2002; Stockli et al., 2002; Lee et al., 2009), particularly where the magnitude of exhumation may be large $(>5 \mathrm{~km})$. Zircon retains helium at higher temperatures than apatite, up to about $\sim 200^{\circ} \mathrm{C}$, with the PRZ covering from $\sim 130^{\circ} \mathrm{C}$ to $\sim 190^{\circ} \mathrm{C}$ (Reiners et al., 2002; 2004; Wolf and Stockli, 2010). However, the zircon helium PRZ is not as well understood due to the complexities of He diffusion in zircon (Fig. 6). This complexity is mainly driven by radiation damage effects on the crystal lattice, specifically its impact on diffusion pathways and activation energy, which together control the kinetics of He diffusion (e.g., Hurley, 1952; Reiners et al., 2002, 2004; Nasdala et al., 2004; Reich et al., 2007; Guenthner et al., 2014. The damage is mainly produced by U and Th recoil during alpha decay and can be identified in analyses by positive or negative correlations between $(\mathrm{U}-\mathrm{Th}) / \mathrm{He}$ dates and effective $\mathrm{U}$ concentration, [U]e. The [U]e is calculated as: $[\mathrm{U}]+0.235[\mathrm{Th}]+0.005[\mathrm{Sm}]$, which is the sum of the parent isotopes $(\mathrm{U}$, Th, and Sm) concentrations measured in grains. The weights applied to the concentrations reflect each isotope's alpha production. A positive trend between dates and [U]e may develop with low levels of damage, suggesting a decrease in He diffusivity (Guenthner et al., 2013). This low-level damage can create a more complicated path for diffusion, trapping ${ }^{4} \mathrm{He}$, something that has also been recognized in radiation damaged apatite (Shuster et al., 2006; Flowers et al., 2009). However, a negative trend between dates and $[\mathrm{U}] \mathrm{e}$ is often a sign of higher levels of radiation damage and the development of fast 
diffusion pathways within grains (Nasdala et al., 2004; Reiners, 2005; Guenthner et al., 2013).

In addition to radiation damage effects, there are a few other complications that needs to be considered with the use of (U-Th)/He thermochronometry. For apatite dating, the presence of U- and Th-rich inclusions, typically zircon, monazite, or xenotime, within crystals is problematic (Farley, 2002; Ehlers and Farley, 2003). These inclusions will undergo decay and emit alpha particles into the host grain, but the associated parent isotopes may not be dissolved and recovered by standard nitric acid-based dissolution procedures used on apatite. This can lead to excess or parentless helium and anomalously old apatite ages. Thus, screening and selection of crystals that are inclusion-free is a critical step in apatite (U-Th)/He analysis.

Another consideration in (U-Th)/He dating is the size of the grains analyzed (Reiners and Farley, 2001). Diffusion experiments have shown that the diffusion length-scale is the grain itself and that He loss is fundamentally controlled by crystal size (Wolf et al., 1996; Farley, 2000). Thus, under the same thermal conditions, crystals of different sizes can produce very different ages, with small grains younger than large grains (Reiners and Farley, 2001). Grain size is also a factor in the primary retention (not to be confused with diffusive loss) of He in grains. Alpha particles produced by the decay of $\mathrm{U}, \mathrm{Th}$, and $\mathrm{Sm}$, are emitted with large enough kinetic energy to move through the solid crystal before coming to rest (called the 'stopping distance'; Farley et al., 1996). The strongest control on the stopping distance is the density of the material (Farley et al, 1996). For example, the density difference from $3.2 \mathrm{~g} / \mathrm{cm}^{3}$ for apatite density to $4.4 . \mathrm{g} / \mathrm{cm}^{3}$ for zircon results in a reduction of the average alpha stopping distance in the ${ }^{238} \mathrm{U}$ chain from 19.7 to $16.6 \mu \mathrm{m}$, 
respectively (Farley et al., 1996 and references therein). The stopping distance can lead to spatial differentiation and loss (ejection) of ${ }^{4} \mathrm{He}$ on the margins of grains. For large grains, the loss would represent a small fraction of the total $\mathrm{He}$, but for small grains, the long alpha stopping distance can result in a substantial fraction of the alpha particles being ejected from the crystal, leading to incorrect and younger ages. To account for this, Farley et al (1996) developed a correction, $\mathrm{F}_{\mathrm{T}}$, for the measured (U-Th)/He age, which is calculated as

a function of the size and the morphology of the dated crystal (i.e., surface-to-volume ratio). The measured age must be divided by the $\mathrm{F}_{\mathrm{T}}$ factor to obtain an alpha-ejection corrected age.

\section{Analytical Procedures}

We used standard mechanical (jaw crusher, disk mill, water table), electromagnetic (Frantz iodynamic magnetic separator), and heavy liquids (bromoform and methylene iodide) separation techniques to process our samples and concentrate the minerals of interest, zircon and apatite. Sample processing was performed at the University of Kansas, Isotope Geochemistry Lab. Next, the individual grains were examined, dimensions measured, and photographed for archive using a stereomicroscope with a mounted digital camera. We aimed to select euhedral grains, greater than $60 \mu \mathrm{m}$ in width that were also free of cracks and inclusions, following the guidelines in Reiners (2005). Cracks within grains can create fast-diffusion pathways that result in anomalously young ages. As described above, inclusions are a particular problem for analysis of apatite because they commonly contain parent isotope concentrations that are higher than the host grain and can incompletely dissolve, resulting in older ages (House et al., 1999; Farley and Stockli, 2002). Additionally, inclusions near the margin of a grain can alter the parent isotope 
distributions, which would be unaccounted for using the standard morphometric age correction $\left(\mathrm{F}_{\mathrm{T}}\right)$.

Once measured, single grains were loaded into a $1 \mathrm{~mm}$ platinum packet and heated using a continuous-mode laser. Zircon crystals were heated for $10 \mathrm{~min}$ at $\sim 1300^{\circ}$; apatite crystals for 5 min at $\sim 1070^{\circ}$ using a Fusions Diode laser system. The extracted gas was spiked with ${ }^{3} \mathrm{He}$ tracer, purified by a Janis cryogenic cold trap at $40 \mathrm{~K}$, and SAES NP-10 getter before measured the ${ }^{4} \mathrm{He} /{ }^{3} \mathrm{He}$ using Blazers Prisma QMS-200 quadrupole mass spectrometer. All zircon grains were reheated under the same heating schedule until ${ }^{4} \mathrm{He}$ yield dropped below < 1\% (Wolfe and Stockli, 2010; Hart et al., 2017). Once degassed, zircons were removed from their packets and dissolved in using U-Pb high-pressure vessel digestion procedures and then spiked with ${ }^{230} \mathrm{Th},{ }^{235} \mathrm{U}$, and ${ }^{149} \mathrm{Sm}$. Apatite crystals, on the other hand, were dissolved in their packets using a spiked $\mathrm{HNO}_{3}$ solution. Dissolved grains were analyzed for parent isotope concentrations using a Thermo Scientific Element 2 - inductively coupled plasma-mass spectrometer. All analytical work was performed at the (U-Th)/He and U-Pb Geo-Thermochronometry Lab at University of Texas at Austin.

\section{Error Reporting}

The analytical uncertainty range for single-grain (U-Th)/He analyses is $\sim 3-4 \%(2 \sigma)$. However, uncertainties associated with nonuniform parent isotope distributions as well as the $\mathrm{F}_{\mathrm{T}}$ correction are challenging to quantify. The often-poor age reproducibility of grains from the same sample suggests that the analytical uncertainties do not adequately represent the true age uncertainty. To address this issue, we follow a common practice in (U-Th)/He dating and apply a percentage error to the single-grain analyses: $6 \%$ error for apatite and 8\% error for zircon, following Farley et al. (2001) and Reiners et al. (2002). These errors 
are based on the typical reproducibility of laboratory standards, commonly the Durango apatite and Fish Canyon tuff. For the mean ages, the error is reported as the standard deviation $(1 \sigma)$ of our replicates for a given sample.

\section{U-Pb Geochronology}

Although not the main focus of this study, we also explored the age signatures of sedimentary units in the hanging wall of the PED using detrital zircon U-Pb geochronology. The U-Pb system is based on three independent decay schemes: ${ }^{238} \mathrm{U} \rightarrow{ }^{206} \mathrm{~Pb}$ with a half-life of $4.47 \mathrm{Ga},{ }^{235} \mathrm{U} \rightarrow{ }^{207} \mathrm{~Pb}$ with a half-life of $0.7 \mathrm{Ga}$, and ${ }^{232} \mathrm{Th} \rightarrow{ }^{208} \mathrm{~Pb}$, with a half-life of 14.01 Gs (Jaffey et al., 1971). For detrital zircon studies, the isotopes of interest are measured using a laser ablation-inductively coupled plasma spectrometer (LA-ICPMS) system. In this method, a laser carves material out either from a polished epoxy grain mount or from a sticky tape mount, and the ablated material is ionized for analysis in a mass spectrometer (e.g., Fryer et al. 1993; Kosler et al. 2001; Kosler and Sylvester, 2003). Detrital zircon U-Pb ages acquired through LA-ICPMS are particularly useful for understanding the sedimentary provenance and maximum depositional age of a unit (Dickinson and Gehrels, 2009; Pullen et al., 2014) because large numbers (100-300) of grains can be analyzed quickly (typically 1 minute per laser spot), with spatial resolution limited by laser spot size (commonly 10-30 $\mu \mathrm{m}$ ), and at a relatively low cost. Importantly, the resulting $\mathrm{U}-\mathrm{Pb}$ ages are also accurate and relatively precise, with analytical uncertainties on the order of 1-2\%, despite the rapid acquisition rate (Feng et al., 1993; Fryer et al., 1993; Hirata and Nesbitt, 1995; Horn et al., 2000; Li et al., 2000). 
In this study, sedimentary samples were processed and separated using the same procedures described above for bedrock thermochronology samples. Once separated, zircon concentrates were divided using a mechanical splitter. All recognizable zircon grains from splits were identified and picked under a binocular microscope and mounted onto $25 \mathrm{~mm}$ diameter epoxy pucks covered with double-sided tape (tape mount). Mounted grains were photographed and labeled for U-Pb spot analysis. Although we aimed to analyze a large number of grains $(\sim 300)$ in order to ensure that all age groups and particularly the youngest grains, which constrain maximum depositional age of the sample, were captured (Dickinson and Gehrels, 2009; Pullen et al., 2014), the samples did not yield a sufficient number of zircons. Two of the samples yielded less than 100 grains, and the other $\sim 175$ zircons.

Laser ablation-inductively coupled plasma mass spectrometry (LA-ICPMS) analyses were performed at UTChron Geo- and Thermochronometry Laboratories at the University of Texas at Austin. The primary reference material, GJ1, with a ${ }^{206} \mathrm{~Pb} /{ }^{238} \mathrm{U}$ age of $601.7 \pm 1.3 \mathrm{Ma}$ and a ${ }^{207} \mathrm{~Pb} /{ }^{206} \mathrm{~Pb}$ of $607 \pm 4 \mathrm{Ma}$ (Jackson et al, 2004, Kylander-Clark et al., 2013), was used to address calibration drift and downhole fractionation. GJI was analyzed once for every 5-8 unknowns. The secondary zircon standard used was Plesovic (337 Ma, Slama et al., 2008).

U-Pb data were reduced using Iolite 3.7 (Igor Pro) (Hellstrom et al., 2008; Paton et al., 2011). U-Pb ages are reported using the absolute error $(2 \sigma)$, propogated by quadratic addition. However, reproducibility and age uncertainty of the reference material are not propagated The discordance between $\mathrm{U}-\mathrm{Pb}$ ages was also evaluated in order to identify analyses that should be excluded, due to lead loss or other factors (e.g., grain zoning), from 
further evaluation. Grains with greater than $10 \%$ discordance or $5 \%$ reverse discordance were excluded. For our U-Pb ages $>850 \mathrm{Ma}$, the discordance was determined based on ${ }^{206} \mathrm{~Pb} /{ }^{238} \mathrm{U}$ and ${ }^{207} \mathrm{~Pb} /{ }^{206} \mathrm{~Pb}$ ages. For zircon ages younger than $850 \mathrm{Ma}$, the discordance was calculated based on ${ }^{206} \mathrm{~Pb} /{ }^{238} \mathrm{U}$ and ${ }^{207} \mathrm{~Pb} /{ }^{235} \mathrm{U}$ ages. 

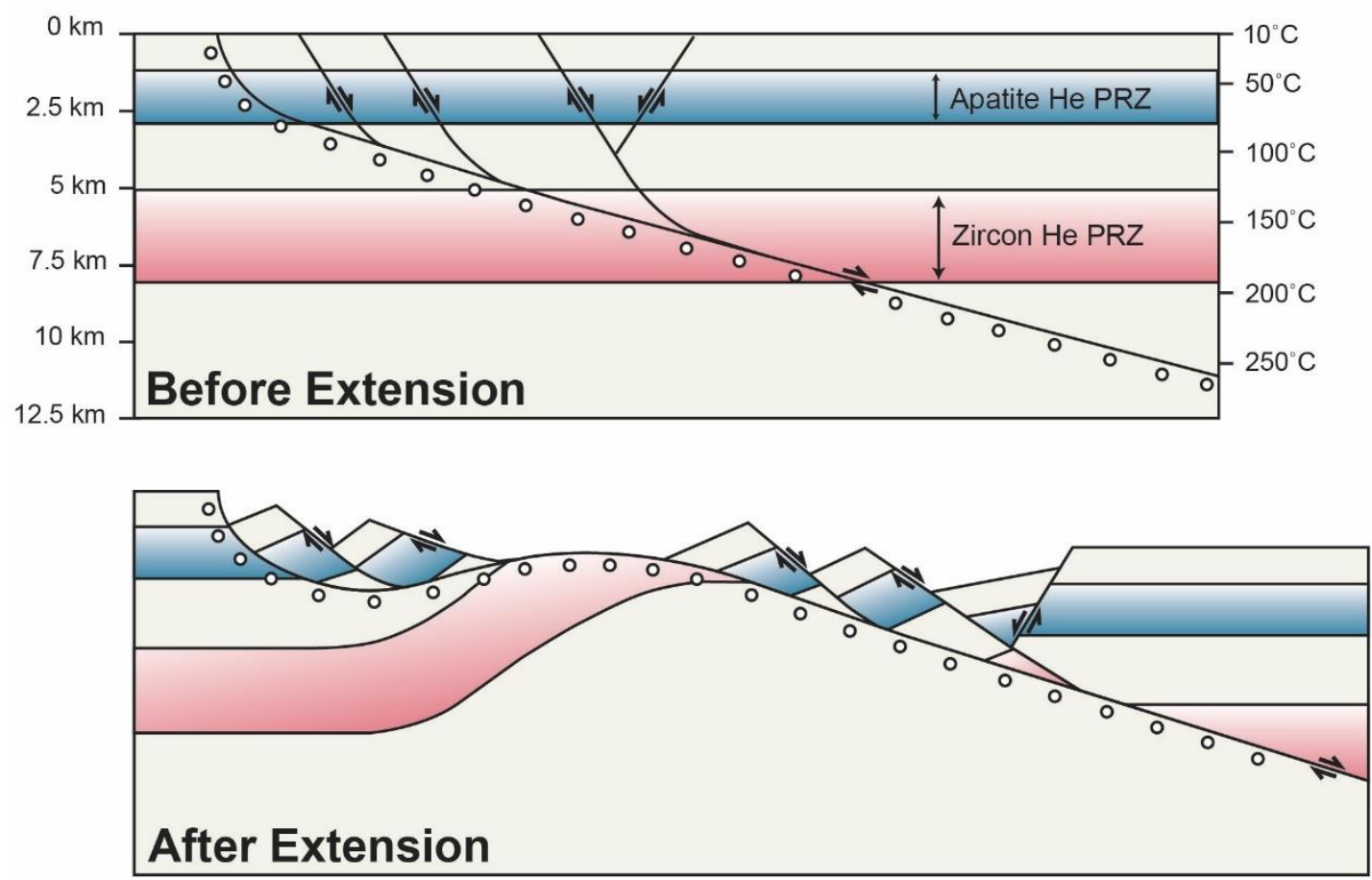

Figure 6. Schematic diagram showing a low-angle normal fault, the He PRZs for apatite and zircon before and after extension, and the positions of hypothetical samples (circles) from a transect perpendicular to the strike of the fault (modified from Stockli (2005)). 


\section{RESULTS}

\section{(U-Th)/He Thermochronology}

Tables 1 and 2 show our (U-Th)/He zircon and apatite mean ages and associated standard deviations $(1 \sigma)$ for Skidoo Pluton (19SP) transect, Goler Canyon (12GC) transect, Panamint Range sites (19PR), and Hunter Mountain (12HM) transect (see Appendices A and B for the full suite of (U-Th)/He data). The majority of the reported mean ages were determined using 3 or more replicates; however, 13 of the 57 reported ages were determined using only 1 or 2 grains. These samples either lacked suitable grains for analysis, had replicates lost during analysis, or contained outliers that were excluded from the mean age determinations. For apatite, outliers were determined as dates larger than $2 \sigma$ from the mean age. In total, 4 (3.9\%) of the 104 single-grain apatite analysis were excluded (Appendix B).

For our zircon ages, outlier analysis was more complicated due to the likely effects of radiation damage on grains (e.g. Hurley, 1952; Reiners et al., 2002, 2004; Nasdala et al., 2004; Reich et al., 2007; Guenther et al., 2014). It can be seen in Table 1 that many of the standard deviations $(1 \sigma)$ are larger than $20 \%$ of the reported mean ages. The strong dispersion in dates is consistent with the negative correlation between [U]e and the (UTh)/He dates observed for many of the zircon samples, particularly for the Hunter Mountain and Goler Canyon samples (Fig. 7A). Figure 7A also shows that there is a wide range in [U]e of the samples, from $<100 \mathrm{ppm}$ to $>2000 \mathrm{ppm}$ (Fig. 7A). Considering radiation damage and its potential impact on closure temperatures, only 4 (5.5\%) of the 73 
single-grain zircon analyses completed were excluded. Grains that were excluded are z19SP01-2, z12GC04-1, z12GC13-3, z12HM06-4, 19SP04-1, 12GC10-1, 19PR05-3 and 12HM07-4 (Appendix A).

The apatite data were also evaluated for potential radiation damage effects. Figure 7B shows the range in [U]e for the samples is from $<10 \mathrm{ppm}$ to $>120 \mathrm{ppm}$. Similar to zircon data, there is a negative correlation between e[U] and the (U-Th)/He ages, particularly for the Hunter Mountain and Goler Canyon datasets (Fig. 7B).

In addition to screening for radiation damage effects, we interrogated the data for grain size effects (Dodson, 1973; Farley, 2000; Reiners and Farley, 2001). Figure 8 shows that the mass of zircon grains, a proxy for size, varies from $<5 \mu \mathrm{g}$ to $<60 \mu \mathrm{g}$; whereas, apatite grains showed less mass variability, ranging from $<5 \mu \mathrm{g}$ to $<20 \mu \mathrm{g}$. No obvious trend were observed between the mass and (U-Th)/He ages, indicating that grain size was not a factor in our results (Fig. 8).

\section{Skidoo Pluton}

Cross-section A-A' (Fig. 9) is oriented east-west and shows the geometries of the Towne Pass fault, Panamint-Emigrant detachment, and Harrisburg fault and the projected positions of the thermochronology samples from the northern Panamint Range. Five samples were collected from monzogranite of the Skidoo Pluton (Fig. 4), located in footwall of the PED, and a total of 13 single-grain zircon dates were recovered (Appendix A). For all but one sample 3 replicates were obtained and reported zircon He mean ages range from as old as $19.0 \pm 0.5 \mathrm{Ma}$ to as young as $4.9 \pm 0.4 \mathrm{Ma}$ (Table 1). A single date $(18.1 \pm 1.5 \mathrm{Ma})$ was recovered from sample z19SP01; however, because the data overlaps 
the mean age for adjacent sample (z19SP02), it was deemed reliable. Cooling ages increase with increasing elevation and eastward across the range (Fig. 9 and 10). The youngest mean ages are located in the very western part of the transect, located just east of the PED.

Apatite analyses from the same samples yielded 16 single-grain dates, with all but one of the reported ages based on three or more replicates (Appendix B). Reported apatite He ages range from as old as 7.5 $\pm 2.2 \mathrm{Ma}$ to as young as $1.5 \pm 0.1 \mathrm{Ma}$ (Table 2). However, the youngest age, obtained for sample 19SP05, is based on a single date. Because this grain is younger than ages acquired structurally above and below, it was deemed questionable and excluded from further analysis. Similar to zircon data, the apatite cooling ages increase with increasing elevation and from west to east across the range (Figs. 9 and 10).

\section{Goler Canyon}

Cross-section B-B' (Fig. 9) is oriented east-west and shows the geometry of the Emigrant detachment, southern Panamint Valley and Butte Valley faults, as well as the older Goldberg thrust near Goler Canyon in the southern part of the Panamint Range. A total of 15 samples were collected principally from quartz monzonite and hornblende diorite in the footwall of the Emigrant detachment (Fig. 4), resulting in 27 single-grain zircon dates (Fig. 8; Appendix A). For seven of the samples (z12GC01, z12GC02, z12GC03, z12GC05, z12GC09, z12GC10, z12GC15), three replicates were obtained (Table 1). Reported zircon He mean ages range from as old as $84 \pm 13$ Ma to as young as $53.2 \pm 14 \mathrm{Ma}$ (Figs. 8). In the western part of the transect, cooling ages increase with increasing elevation (Fig. 9 and 10). The youngest mean ages, with the exception of sample $\mathrm{z} 12 \mathrm{GC0}$, are located in the western part of the transect, and the eastern part of the transect 
contains the oldest ages, older than $80 \mathrm{Ma}$ (z12GC02) (Fig. 9). No zircons were recovered from samples z12GC06, z12GC1, z12GC12, z12GC13 and z12GC14.

Apatite analyses from the same samples yielded a total of 40 single-grain apatite dates (Appendix B). All but two of the samples analyzed had three or more replicates dated (Table 2). Reported apatite He mean ages range for this transect from as old as $36.0 \pm 2.4$ Ma to as young as $3.9 \pm 0.5 \mathrm{Ma}$, and the cooling ages show the similar pattern as the zircon He ages (Fig. 9). The youngest mean ages are located in the very western part of the transect and cluster around $4 \mathrm{Ma}$. The youngest ages become progressively older with increasing elevation and eastward across the range. However, these trend shift to younger ages east of sample 12GC07, with easternmost and highest elevation samples clustering at 8-9 Ma (Figs. 8 and 9). No apatite was recovered from samples 12GC11, 12GC12, and 12GC14.

\section{Panamint Range Sites}

We collected 5 samples from two different sites along the Panamint Range front (Fig. 4). Three of samples were collected from the north-central part of the range, near Hall Canyon and two of the samples from the south-central part of the range, near Redlands Canyon (Fig. 4). In total,13 single-grain zircon dates were obtained and zircon He mean ages range from as old as $29.3 \pm 5.4 \mathrm{Ma}$ to as young as $7.0 \pm 1.0 \mathrm{Ma}$ (Table 1; Appendix A). However, no clear trend was observed between the cooling ages and elevation (Fig. 10). The youngest ages from the Panamint Range sites are $7.0 \pm 1.0$ and $10.1 \pm 2.5 \mathrm{Ma}$ (z19PR03, z19PR05) and the oldest age is a little younger than $30 \mathrm{Ma}$ (z19PR01) (Fig. 10).

Apatite analyses from these same samples yielded a total of 14 apatite single-grain dates (Appendix B). Three or more replicates were obtained from four of the samples, with 
mean ages ranging from as old as $5.8 \pm 1.8 \mathrm{Ma}$ to as young as $2.6 \pm 0.3 \mathrm{Ma}$ (Table 2). However, no clear trend was observed between the cooling ages and elevation or position within the range (Fig. 10). No apatite was recovered from the sample 19PR03.

\section{Hunter Mountain}

We analyzed 8 samples from a NE-SW transect across leucomonzogabbros of the Hunter Mountain batholith and recovered a total of 18 zircon and 30 apatite dates (Appendices A and B). Reported zircon He mean ages range from as old as $100.8 \pm 8 \mathrm{Ma}$ to as young as $70 \pm 19 \mathrm{Ma}$, but only half of the samples had a suitable number of replicates (Table 1). Apatite He mean ages range from as old as $77 \pm 10 \mathrm{Ma}$ to as young as $61.3 \pm 2.0$ Ma (Table 2). No clear trend was observed in either dataset between the elevation and mean age of the samples (Fig. 10).

\section{U-Pb Geochronology}

Appendix $\mathrm{C}$ shows our detrital zircon $\mathrm{U}-\mathrm{Pb}$ ages and errors $(2 \sigma)$ from three samples of the Nova Formation (Fig. 4). Zircons from clasts and matrix were analyzed separately for each sample. All detrital zircon U-Pb analyses are displayed as kernel density estimation plots (Fig. 11) and were constructed using Density Plotter (Vermeesch, 2012).

A total of 375 detrital zircon grains were analyzed and a total of 272 grains yielded ages with $>10 \%$ discordance and $>5 \%$ reverse discordance. These $\mathrm{U}-\mathrm{Pb}$ ages range from 3 Ma to $3206 \mathrm{Ma}$ (Fig. 11). It is important to emphasize that the number of grains analyzed for each sample was restricted due to low zircon recovery and only 11 to 56 grains were analyzed from our samples, with the exception of the coarse fraction of our sample from 
the middle Nova Formation (19NB02_clasts) (n=120) (Fig. 11). Although larger grain populations $(n>120)$ would have been preferable in terms of the reliability and utility of the dataset (Vermeesch, 2004; Andersen, 2005), the data still provide some constraints on the geologic history, and the data seem to be support the published stratigraphic work in the region (Hodges et al., 1989; Snyder and Hodges, 2000).

Detrital zircon $\mathrm{U}-\mathrm{Pb}$ ages were determined on 88 grains from a sample of the lower Nova Formation (Fig.11; Appendix C). The grains that were obtained from the clasts $(n=32)$ are generally early and middle Proterozoic, with ages that range from 1697-1798 Ma and 1038-1127 Ma; whereas matrix grains $(n=56)$ are mostly middle Proterozoic, with ages ranging from 1680-1787 Ma (Fig. 11). The age distributions show prominent clusters between1680-1798 Ma, 1060-1192 Ma and 1208-1388 Ma. The youngest grains, dated 4.2 \pm 0.2 and $4.8 \pm 0.3 \mathrm{Ma}$, are from clasts and provide a maximum depositional age constraint for the sample.

Similarly, detrital zircon $\mathrm{U}-\mathrm{Pb}$ ages were determined from a sample of the middle Nova Formation (Fig, 11; Appendix C). A total of 146 grains were analyzed from this sample. The clast-derived grains $(n=120)$ are mostly early Proterozoic, with ages dominantly between 1603-1796 Ma; whereas grains from the matrix ( $\mathrm{n}=26)$ are mostly middle Proterozoic with ages between 1020-1168 Ma (Fig. 11). Major ages clusters of 1603-1796 Ma, 1440-1551 Ma, and 1020-1183 Ma were recognized. No Miocene or Pliocene zircons were recovered from this sample.

Lastly, detrital zircon $\mathrm{U}-\mathrm{Pb}$ ages were determined on 38 grains from a sample of the the upper Nova Formation (Fig.11; Appendix C). The clast-derived grains $(n=27)$ are mostly middle Proterozoic with ages range from 1409 and 1593 Ma, Matrix grains (n=11) 
are also middle Proterozoic, with ages ranging from $1424 \mathrm{Ma}$ and $1486 \mathrm{Ma}$, and early Proterozoic, with ages ranging from $1832 \mathrm{Ma}$ and $1859 \mathrm{Ma}$ (Fig. 11). The ages show age clusters of 1157-1190 Ma, 1409-1593 Ma, and 1654-1753 Ma. The youngest grain from this sample is $3 \pm 0.2 \mathrm{Ma}$, providing an important maximum depositional age constraint for the upper Nova Formation. 


\begin{tabular}{|c|c|c|c|c|c|c|c|c|c|c|c|c|c|c|}
\hline Sample & $\begin{array}{c}\text { Latitude } \\
(\mathrm{N})\end{array}$ & $\begin{array}{c}\text { Longitude } \\
\text { (W) }\end{array}$ & $\begin{array}{c}\text { Elevation } \\
\text { (m) }\end{array}$ & $\begin{array}{l}\begin{array}{l}\text { Mass } \\
(\mathrm{mg})\end{array} \\
\end{array}$ & $\mathrm{Ft}^{*}$ & $\begin{array}{c}\mathrm{U} \\
(\mathrm{ppm})\end{array}$ & $\begin{array}{c}\text { Th } \\
(\mathrm{ppm})\end{array}$ & $\begin{array}{c}\begin{array}{c}\text { Sm } \\
\text { (ppm) }\end{array} \\
\end{array}$ & [U]e & $\mathrm{Th} / \mathrm{U}$ & $\begin{array}{c}\begin{array}{c}\mathrm{He} \\
(\mathrm{nmol} / \mathrm{g})\end{array} \\
\end{array}$ & $\begin{array}{c}\text { Mean age } \\
\text { (Ma) }\end{array}$ & $\begin{array}{c}\text { St. dev. } \\
\text { (Ma) }\end{array}$ & Replicates \\
\hline \multicolumn{15}{|c|}{ Skidoo Pluton zircon data } \\
\hline z19SP01 & $36^{\circ} 25^{\prime} 42.11^{\prime \prime}$ & $117^{\circ} 8^{\prime} 3.44^{\prime \prime}$ & 1842 & 5.98 & 0.77 & 209.8 & 169.7 & 117.7 & 249.5 & 0.81 & 18.8 & 18.09 & - & 1 \\
\hline z19SP02 & $36^{\circ} 25^{\prime} 52.42^{\prime \prime}$ & $117^{\circ} 8^{\prime} 31.98$ & 1820 & 8.95 & 0.79 & 372.1 & 76.6 & 1.3 & 389.7 & 0.32 & 31.3 & 18.98 & 0.54 & 3 \\
\hline z19SP03 & $36^{\circ} 26^{\prime} 7.41^{\prime \prime}$ & $117^{\circ} 9^{\prime 11} .74^{\prime \prime}$ & 1726 & 20.39 & 0.83 & 507.8 & 50.8 & 1.1 & 519.5 & 0.22 & 25.5 & 11.94 & 2.43 & 3 \\
\hline z19SP04 & $36^{\circ} 25^{\prime} 42.22^{\prime \prime}$ & $117^{\circ} 11^{\prime} 4.51^{\prime \prime}$ & 1373 & 6.76 & 0.77 & 610.4 & 113.4 & 0.9 & 636.5 & 0.2 & 13.4 & 4.86 & 0.38 & 3 \\
\hline z19SP05 & $36^{\circ} 26^{\prime} 35.00^{\prime \prime}$ & $117^{\circ} 9^{\prime} 51.00^{\prime \prime}$ & 1540 & 7.8 & 0.78 & 798.1 & 100.2 & 3.2 & 821.2 & 0.45 & 28.6 & 9.21 & 3.69 & 3 \\
\hline \multicolumn{15}{|c|}{ Goler Canyon zircon data } \\
\hline $\mathrm{z} 12 \mathrm{GC} 01$ & $35^{\circ} 52^{\prime} 0.82^{\prime \prime}$ & $117^{\circ} 5^{\prime} 53.46^{\prime \prime}$ & 1038 & 18.93 & 0.82 & 107 & 78.7 & 3.5 & 125.2 & 0.76 & 43.2 & 77.55 & 8.59 & 3 \\
\hline $\mathrm{z} 12 \mathrm{GC} 02$ & $35^{\circ} 51^{\prime} 48.91^{\prime \prime}$ & $117^{\circ} 6^{\prime} 6.55^{\prime \prime}$ & 1019 & 6.43 & 0.76 & 117 & 73.2 & -2.6 & 133.8 & 0.68 & 45.9 & 84.12 & 14.59 & 3 \\
\hline $\mathrm{z} 12 \mathrm{GC} 03$ & $35^{\circ} 51^{\prime} 48.89^{\prime \prime}$ & $117^{\circ} 6^{\prime 21.49^{\prime \prime}}$ & 1071 & 7.12 & 0.77 & 127.5 & 89.2 & 0 & 148 & 0.7 & 42.3 & 70.14 & 16.56 & 3 \\
\hline z12GC04 & $35^{\circ} 52^{\prime} 0.01^{\prime \prime}$ & $117^{\circ} 6^{\prime} 36.44^{\prime \prime}$ & 1040 & 10.7 & 0.8 & 146.09 & 85.49 & 1.31 & 165.78 & 0.58 & 45.32 & 63.21 & 1.75 & 2 \\
\hline $\mathrm{z} 12 \mathrm{GC} 05$ & $35^{\circ} 51^{\prime} 37.73^{\prime \prime}$ & $117^{\circ} 6^{\prime} 55.40^{\prime \prime}$ & 860 & 6.36 & 0.76 & 113 & 81.5 & -4.2 & 131.7 & 0.74 & 42 & 79.3 & 2.32 & 3 \\
\hline z12GC07 & $35^{\circ} 51^{\prime} 32.34^{\prime \prime}$ & $117^{\circ} 7^{\prime 2} 27.55^{\prime \prime}$ & 890 & 4.43 & 0.74 & 262.45 & 91.11 & -10.43 & 283.37 & 0.35 & 90.97 & 79.5 & 0.67 & 2 \\
\hline $\mathrm{z} 12 \mathrm{GC} 08$ & $35^{\circ} 51^{\prime} 33.56^{\prime \prime}$ & $117^{\circ} 7^{\prime} 46.54^{\prime \prime}$ & 817 & 3.49 & 0.72 & 94.88 & 75.67 & 0 & 112.3 & 0.77 & 30.5 & 68.45 & 7.51 & 2 \\
\hline z12GC09 & $35^{\circ} 51^{\prime} 33.13^{\prime \prime}$ & $117^{\circ} 8^{\prime} 3.50^{\prime \prime}$ & 809 & 5.55 & 0.75 & 72.8 & 47.2 & 20.2 & 83.8 & 0.63 & 28.2 & 81.76 & 4.28 & 3 \\
\hline $\mathrm{z} 12 \mathrm{GC} 10$ & $35^{\circ} 51^{\prime} 37.23^{\prime \prime}$ & $117^{\circ} 8^{\prime 21.23^{\prime \prime}}$ & 765 & 2.56 & 0.7 & 123.1 & 106.3 & 0 & 147.6 & 0.76 & 36.9 & 63.63 & 3.81 & 3 \\
\hline $\mathrm{z} 12 \mathrm{GC} 15$ & $35^{\circ} 51^{\prime} 27.13^{\prime \prime}$ & $117^{\circ} 9^{\prime} 14.22^{\prime \prime}$ & 515 & 3.7 & 0.73 & 34.8 & 30.1 & 0 & 41.7 & 0.85 & 8.6 & 53.19 & 14.27 & 3 \\
\hline \multicolumn{15}{|c|}{ Panamint Range Sites zircon data } \\
\hline z19PR01 & $35^{\circ} 55^{\prime} 18.00^{\prime \prime}$ & $117^{\circ} 10^{\prime} 58.00^{\prime \prime}$ & 425 & 12.56 & 0.81 & 113.1 & 60.3 & 1.5 & 127 & 0.5 & 16.3 & 29.29 & 5.42 & 3 \\
\hline z19PR02 & $35^{\circ} 55^{\prime} 18.00^{\prime \prime}$ & $117^{\circ} 11^{\prime} 6.00^{\prime \prime}$ & 1229 & 15.7 & 0.82 & 123.2 & 50.9 & 2.1 & 135 & 0.45 & 14.3 & 23.55 & 2.26 & 3 \\
\hline z19PR03 & $36^{\circ} 13^{\prime} 1.00^{\prime \prime}$ & $117^{\circ} 13^{\prime} 13.00^{\prime \prime}$ & 1017 & 11.56 & 0.79 & 452 & 359.4 & 2.2 & 534.7 & 0.88 & 16 & 7.03 & 0.96 & 3 \\
\hline z19PR04 & $36^{\circ} 12^{\prime} 54.00^{\prime \prime}$ & $117^{\circ} 13^{\prime} 41.00^{\prime \prime}$ & 1039 & 10.7 & 0.78 & 929.61 & 809.6 & 7178.9 & 1151.87 & 0.66 & 60.02 & 18.52 & 6.38 & 2 \\
\hline z19PR05 & $36^{\circ} 12^{\prime} 39.00^{\prime \prime}$ & $117^{\circ} 13^{\prime} 9.00^{\prime \prime}$ & 925 & 29.45 & 0.81 & 37.15 & 26.07 & 28.11 & 43.3 & 0.84 & 2.15 & 10.08 & 2.49 & 2 \\
\hline \multicolumn{15}{|c|}{ Hunter Mountain zircon data } \\
\hline z12HM01 & $36^{\circ} 32^{\prime} 46.32^{\prime \prime}$ & $117^{\circ} 30^{\prime} 44.45^{\prime \prime}$ & 2210 & 10.51 & 0.79 & 101 & 77.6 & 0 & 118.8 & 0.79 & 47.6 & 89.09 & 16.36 & 3 \\
\hline z12HM02 & $36^{\circ} 32^{\prime} 29.71^{\prime \prime}$ & $117^{\circ} 31^{\prime} 9.35^{\prime \prime}$ & 2100 & 42.72 & 0.88 & 50.7 & 46.9 & 9 & 61.6 & 1.94 & 27.2 & 99.27 & 19.81 & 3 \\
\hline z12HM03 & $36^{\circ} 32^{\prime} 17.17^{\prime \prime}$ & $117^{\circ} 32^{\prime 22} .87^{\prime \prime}$ & 2086 & 26.69 & 0.85 & 80 & 48.2 & 10.5 & 91.1 & 0.61 & 28.7 & 70.02 & 19.32 & 3 \\
\hline z12HM04 & $36^{\circ} 32^{\prime} 8.13^{\prime \prime}$ & $117^{\circ} 32^{\prime} 4.18^{\prime \prime}$ & 2058 & 11.02 & 0.8 & 338.2 & 156.7 & 2.6 & 374.2 & 0.46 & 133.8 & 82.5 & - & 1 \\
\hline z12HM05 & $36^{\circ} 31^{\prime} 48.06^{\prime \prime}$ & $117^{\circ} 32^{\prime} 21.40^{\prime \prime}$ & 1954 & 27.38 & 0.86 & 54.12 & 28.99 & 1.03 & 60.8 & 0.56 & 20.79 & 74.78 & 6.12 & 2 \\
\hline z12HM06 & $36^{\circ} 31^{\prime} 38.48^{\prime \prime}$ & $117^{\circ} 32^{\prime} 44.06^{\prime \prime}$ & 1811 & 44.38 & 0.87 & 71.1 & 69.6 & 1.3 & 87.2 & 0.98 & 41.6 & 100.77 & - & 1 \\
\hline z12HM07 & $36^{\circ} 31^{\prime} 59.94^{\prime \prime}$ & $117^{\circ} 33^{\prime} 40.24^{\prime \prime}$ & 1732 & 13.3 & 0.81 & 110.8 & 63.6 & 0 & 125.4 & 0.58 & 52.2 & 93.78 & 5.14 & 3 \\
\hline z12HM08 & $36^{\circ} 31^{\prime} 46.12^{\prime \prime}$ & $117^{\circ} 33^{\prime} 19.45^{\prime \prime}$ & 1788 & 19.79 & 0.83 & 108.05 & 87.18 & 2.76 & 128.13 & 0.79 & 52.82 & 89.35 & 5.61 & 2 \\
\hline
\end{tabular}




\begin{tabular}{|c|c|c|c|c|c|c|c|c|c|c|c|c|c|c|}
\hline Sample & $\begin{array}{l}\text { Latitude } \\
\text { (N) }\end{array}$ & $\begin{array}{l}\text { Longitude } \\
\text { (W) }\end{array}$ & $\begin{array}{c}\text { Elevation } \\
\text { (m) }\end{array}$ & $\begin{array}{l}\text { Mass } \\
(\mathbf{m g})\end{array}$ & $\mathrm{Ft}^{*}$ & $\begin{array}{c}\mathrm{U} \\
\text { (ppm) }\end{array}$ & $\begin{array}{c}\text { Th } \\
\text { (ppm) }\end{array}$ & $\begin{array}{c}\text { Sm } \\
\text { (ppm) }\end{array}$ & [U]e & $\mathrm{Th} / \mathrm{U}$ & $\begin{array}{c}\mathrm{He} \\
(\mathrm{nmol} / \mathrm{g})\end{array}$ & $\begin{array}{c}\text { Mean age } \\
\text { (Ma) }\end{array}$ & $\begin{array}{l}\text { St. dev. } \\
\text { (Ma) }\end{array}$ & Replicates \\
\hline \multicolumn{15}{|c|}{ Skidoo Pluton apatite data } \\
\hline 19SP01 & $36^{\circ} 25^{\prime} 42.11^{\prime \prime}$ & $117^{\circ} 8^{\prime} 3.44^{\prime \prime}$ & 1842 & 5.74 & 0.73 & 6.3 & 27.2 & 147.9 & 13.3 & 3.11 & 0.3 & 7.5 & 2.16 & 4 \\
\hline 19SP02 & $36^{\circ} 25^{\prime} 52.42^{\prime \prime}$ & $117^{\circ} 8^{\prime} 31.98$ & 1820 & 3.1 & 0.67 & 11.1 & 26.7 & 180.7 & 18.1 & 2.71 & 0.5 & 6.66 & 1.83 & 4 \\
\hline 19SP03 & $36^{\circ} 26^{\prime} 7.41^{\prime \prime}$ & $117^{\circ} 9^{\prime} 11.74^{\prime \prime}$ & 1726 & 7.93 & 0.76 & 9.7 & 21 & 161.8 & 15.3 & 1.79 & 0.4 & 5.7 & 1.13 & 4 \\
\hline 19SP04 & $36^{\circ} 25^{\prime} 42.22^{\prime \prime}$ & $117^{\circ} 11^{\prime} 4.51^{\prime \prime}$ & 1373 & 7.16 & 0.73 & 9.2 & 79.2 & 149.2 & 28.2 & 7.69 & 0.4 & 3.72 & 0.29 & 3 \\
\hline 19SP05 & $36^{\circ} 26^{\prime} 35.00^{\prime \prime}$ & $117^{\circ} 9^{\prime} 51.00^{\prime \prime}$ & 1540 & 2.52 & 0.69 & 8.4 & 3.2 & 111.6 & 9.7 & 0.39 & 0.1 & 1.5 & - & 1 \\
\hline \multicolumn{15}{|c|}{ Goler Canvon apatite data } \\
\hline $12 \mathrm{GC} 01$ & $35^{\circ} 52^{\prime} 0.82^{\prime \prime}$ & $117^{\circ} 5^{\prime} 53.46^{\prime \prime}$ & 1038 & 3.69 & 0.68 & 7.7 & 35.2 & 142 & 16.5 & 5.5 & 0.6 & 9.68 & 1.52 & 4 \\
\hline $12 \mathrm{GC} 02$ & $35^{\circ} 51^{\prime} 48.91^{\prime \prime}$ & $117^{\circ} 6^{\prime} 6.55^{\prime \prime}$ & 1019 & 3.8 & 0.7 & 9.8 & 39.7 & 138.5 & 19.6 & 4.08 & 0.7 & 8.96 & 0.46 & 3 \\
\hline $12 \mathrm{GC} 03$ & $35^{\circ} 51^{\prime} 48.89^{\prime \prime}$ & $117^{\circ} 621.49^{\prime \prime}$ & 1071 & 3.72 & 0.69 & 6 & 33.7 & 204.1 & 14.8 & 5.7 & 0.6 & 10.15 & 1.59 & 3 \\
\hline $12 \mathrm{GC} 04$ & $35^{\circ} 52^{\prime} 0.01^{\prime \prime}$ & $117^{\circ} 6^{\prime} 36.44^{\prime \prime}$ & 1040 & 2.17 & 0.63 & 8.9 & 36.2 & 137.6 & 17.9 & 4.15 & 0.7 & 11.04 & 1.31 & 4 \\
\hline $12 \mathrm{GC} 05$ & $35^{\circ} 51^{\prime} 37.73^{\prime \prime}$ & $117^{\circ} 6^{\prime} 55.40^{\prime \prime}$ & 860 & 3.57 & 0.68 & 6.9 & 31.6 & 184.4 & 15.1 & 4.31 & 0.9 & 18.33 & 7.71 & 4 \\
\hline $12 \mathrm{GC} 06$ & $35^{\circ} 51^{\prime} 35.66^{\prime \prime}$ & $117^{\circ} 7^{\prime 11} 10^{\prime \prime}$ & 849 & 1.86 & 0.64 & 25.7 & 47.7 & 155.3 & 37.5 & 1.86 & 1.8 & 13.97 & 4.36 & 2 \\
\hline $12 \mathrm{GC} 07$ & $35^{\circ} 51^{\prime} 32.34^{\prime \prime}$ & $117^{\circ} 7^{\prime} 27.55^{\prime \prime}$ & 890 & 1.98 & 0.64 & 40.5 & 19.6 & 170.7 & 45.9 & 0.47 & 5.9 & 36.01 & 2.38 & 3 \\
\hline $12 \mathrm{GC} 08$ & $35^{\circ} 51^{\prime} 33.56^{\prime \prime}$ & $117^{\circ} 7^{\prime} 46.54^{\prime \prime}$ & 817 & 2.34 & 0.66 & 11 & 23.9 & 242.9 & 17.7 & 2.57 & 2.2 & 32.23 & 6.48 & 3 \\
\hline $12 \mathrm{GC} 09$ & $35^{\circ} 51^{\prime} 33.13^{\prime \prime}$ & $117^{\circ} 8^{\prime} 3.50^{\prime \prime}$ & 809 & 1.49 & 0.6 & 5.7 & 18.6 & 222.2 & 11.1 & 3.27 & 0.8 & 19.66 & 5.38 & 4 \\
\hline $12 \mathrm{GC} 10$ & $35^{\circ} 51^{\prime} 37.23^{\prime \prime}$ & $117^{\circ} 8^{\prime 21.23^{\prime \prime}}$ & 765 & 4.28 & 0.72 & 7.3 & 15.3 & 192.9 & 11.8 & 2.06 & 0.7 & 14.98 & 1.14 & 2 \\
\hline $12 \mathrm{GC} 13$ & $35^{\circ} 51^{\prime} 29.15^{\prime \prime}$ & $117^{\circ} 8^{\prime} 59.40^{\prime \prime}$ & 665 & 2.75 & 0.68 & 91.2 & 78 & 217 & 110.2 & 0.87 & 1.7 & 4.04 & 0.24 & 4 \\
\hline $12 \mathrm{GC} 15$ & $35^{\circ} 51^{\prime} 27.13^{\prime \prime}$ & $117^{\circ} 9^{\prime} 14.22^{\prime \prime}$ & 515 & 2.43 & 0.66 & 12.8 & 31.3 & 72.7 & 20.4 & 2.54 & 0.3 & 3.85 & 0.47 & 4 \\
\hline \multicolumn{15}{|c|}{ Panamint Range Sites apatite data } \\
\hline 19PR01 & $35^{\circ} 55^{\prime} 18.00^{\prime \prime}$ & $117^{\circ} 10^{\prime} 58.00^{\prime \prime}$ & 425 & 8.16 & 0.75 & 33.7 & 72.7 & 47.5 & 50.7 & 2.14 & 0.6 & 2.83 & 0.1 & 4 \\
\hline 19PR02 & $35^{\circ} 55^{\prime} 18.00^{\prime \prime}$ & $117^{\circ} 11^{\prime} 6.00^{\prime \prime}$ & 1229 & 3.82 & 0.69 & 52.7 & 68.9 & 97.1 & 69 & 1.3 & 0.7 & 2.63 & 0.31 & 3 \\
\hline 19PR04 & $36^{\circ} 12^{\prime} 54.00^{\prime \prime}$ & $117^{\circ} 13^{\prime} 41.00^{\prime \prime}$ & 1039 & 10.88 & 0.78 & 5.1 & 5.9 & 480.6 & 8.8 & 1.19 & 0.2 & 2.78 & 1.86 & 4 \\
\hline 19PR05 & $36^{\circ} 12^{\prime} 39.00^{\prime \prime}$ & $117^{\circ} 13^{\prime} 9.00^{\prime \prime}$ & 925 & 8.5 & 0.7 & 32.2 & 11.1 & 363.7 & 36.6 & 0.6 & 1 & 5.79 & 1.82 & 3 \\
\hline \multicolumn{15}{|c|}{ Hunter Mountain apatite data } \\
\hline $12 \mathrm{HM} 01$ & $36^{\circ} 32^{\prime} 46.32^{\prime \prime}$ & $117^{\circ} 30^{\prime} 44.45^{\prime \prime}$ & 2210 & 2.68 & 0.65 & 20.6 & 55.6 & 47.9 & 33.6 & 2.86 & 8.7 & 71.14 & 2.72 & 4 \\
\hline 12HM02 & $36^{\circ} 32^{\prime} 29.71^{\prime \prime}$ & $117^{\circ} 31^{\prime} 9.35^{\prime \prime}$ & 2100 & 3.71 & 0.68 & 9 & 34.3 & 26.2 & 17 & 3.85 & 4.4 & 69.39 & 1.95 & 4 \\
\hline $12 \mathrm{HM} 03$ & $36^{\circ} 32^{\prime} 17.17^{\prime \prime}$ & $117^{\circ} 32^{\prime} 22.87^{\prime \prime}$ & 2086 & 2.87 & 0.67 & 9.3 & 32.2 & 52.5 & 16.9 & 3.5 & 3.9 & 61.27 & 2.01 & 4 \\
\hline 12HM04 & $36^{\circ} 32^{\prime} 8.13^{\prime \prime}$ & $117^{\circ} 32^{\prime} 4.18^{\prime \prime}$ & 2058 & 1.5 & 0.6 & 13.9 & 50.4 & 128.4 & 26.2 & 3.62 & 6.6 & 75.79 & 8.96 & 4 \\
\hline 12HM05 & $36^{\circ} 31^{\prime} 48.06^{\prime \prime}$ & $117^{\circ} 32^{\prime} 21.40^{\prime \prime}$ & 1954 & 1.6 & 0.61 & 25 & 67.8 & 82 & 41 & 2.94 & 9.4 & 68.89 & 4.93 & 4 \\
\hline 12HМ06 & $36^{\circ} 31^{\prime} 38.48^{\prime \prime}$ & $117^{\circ} 32^{\prime} 44.06^{\prime \prime}$ & 1811 & 3.04 & 0.66 & 19.5 & 55.1 & 47.6 & 32.4 & 3.03 & 8 & 68.68 & 5.61 & 4 \\
\hline $12 \mathrm{HM} 07$ & $36^{\circ} 31^{\prime} 59.94^{\prime \prime}$ & $117^{\circ} 33^{\prime} 40.24^{\prime \prime}$ & 1732 & 3.3 & 0.7 & 9.7 & 44.7 & 32.5 & 20.2 & 4.7 & 5.9 & 79.69 & 9.57 & 3 \\
\hline 12HМ08 & $36^{\circ} 31^{\prime} 46.12^{\prime \prime}$ & $117^{\circ} 33^{\prime} 19.45^{\prime \prime}$ & 1788 & 15.39 & 0.78 & 20.8 & 93.7 & 36.7 & 42.5 & 4.54 & 12.9 & 71.39 & 2.97 & 3 \\
\hline
\end{tabular}



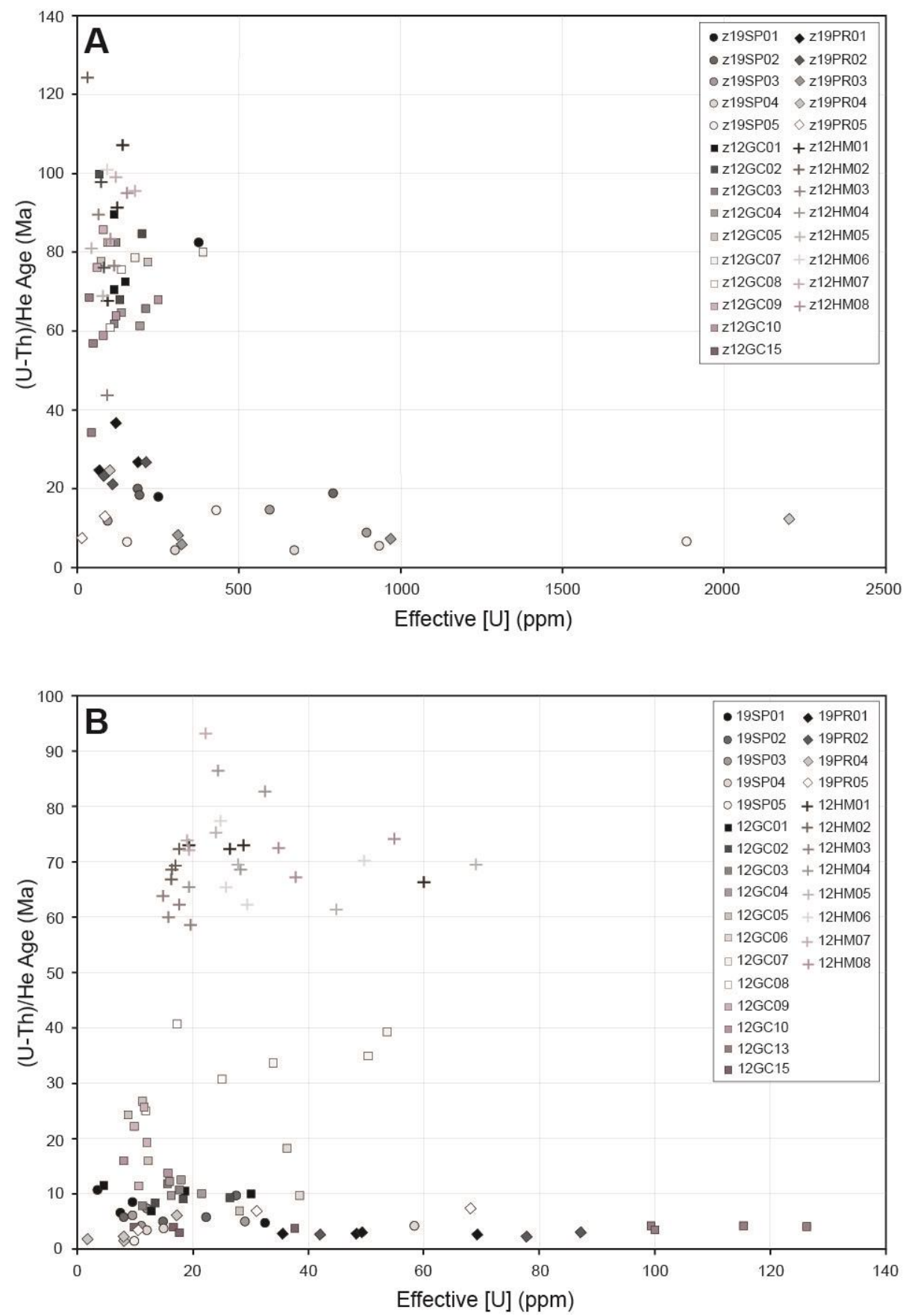

Figure 7. (A) Zircon and (B) apatite (U-Th)/He dates versus [U]e for samples from the Skidoo Pluton, Goler Canyon, Panamint Range sites and Hunter Mountain Batholith. 

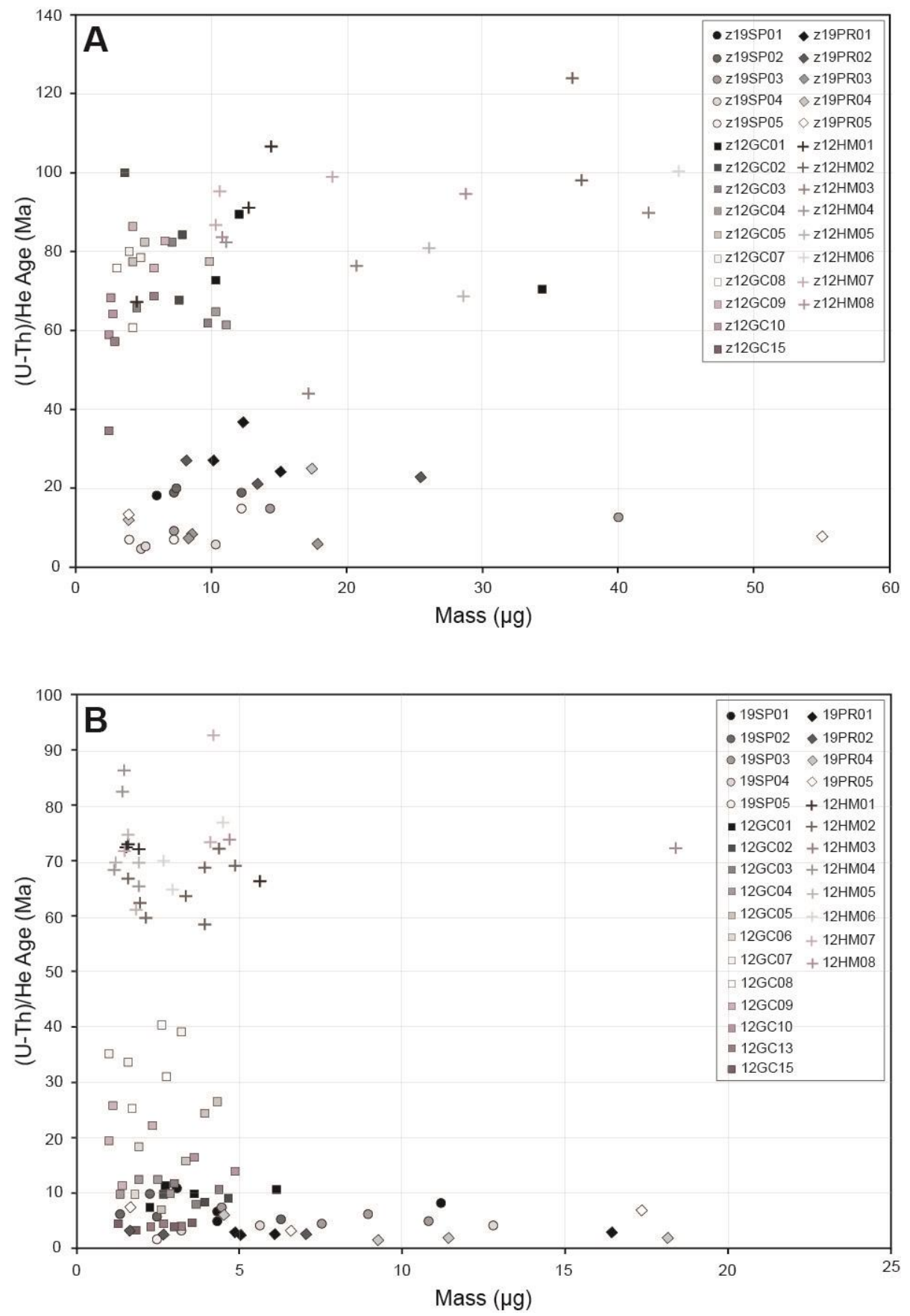

Figure 8. (A) Zircon and (B) apatite (U-Th)/He dates versus mass (grain size) for samples from the Skidoo Pluton, Goler Canyon, Panamint Range Sites, and Hunter Mountain Batholith. 

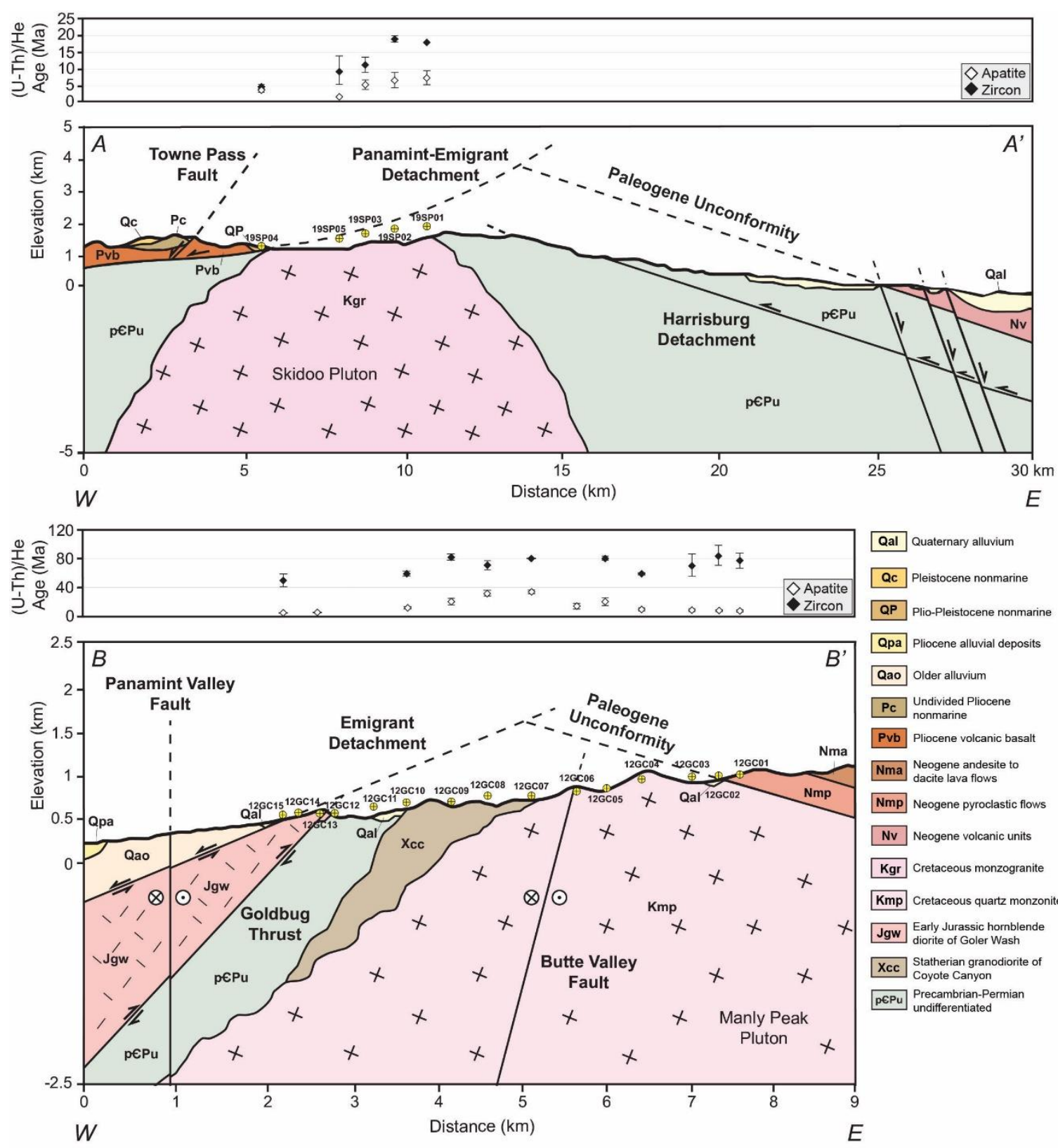

Qpa Pliocene alluvial deposits

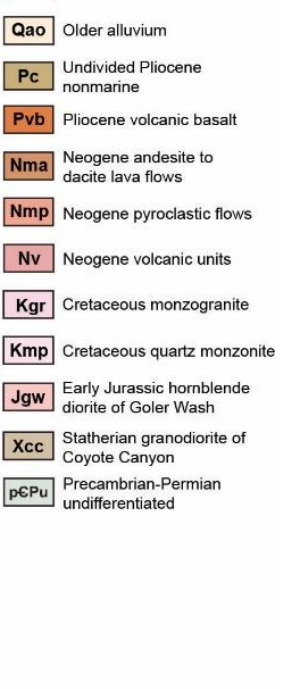

Figure 9. (A) Simplified geologic cross-section A-A' across the Skidoo pluton showing geometries of the Towne Pass, Panamint-Emigrant detachment, and Harrisburg faults. Thermochronology samples, shown as yellow dots, are projected into the plane of the cross-section. All samples were collected from the footwall of the PED, however in this projected view they may be positioned above or below topography of the crosssection line. Cross-section data from Hunt and Mabey (1966), Streitz and Stinson (1974), and compilation of Workman et al. (2002). (B) Simplified geologic cross-section B-B' across the Goler Canyon showing the geometry of the Emigrant detachment, southern Panamint Valley and Butte Valley faults, and the Goldbug thrust in the southern Panamint Range. Cross-section data from Workman et al. (2002) and Andrew (2018). Mean zircon and apatite (U-Th)/He ages and errors ( $1 \sigma$ standard deviation) are plotted as a function of horizontal distance above each cross section. Location of the cross-sections are shown in Figure 4. 

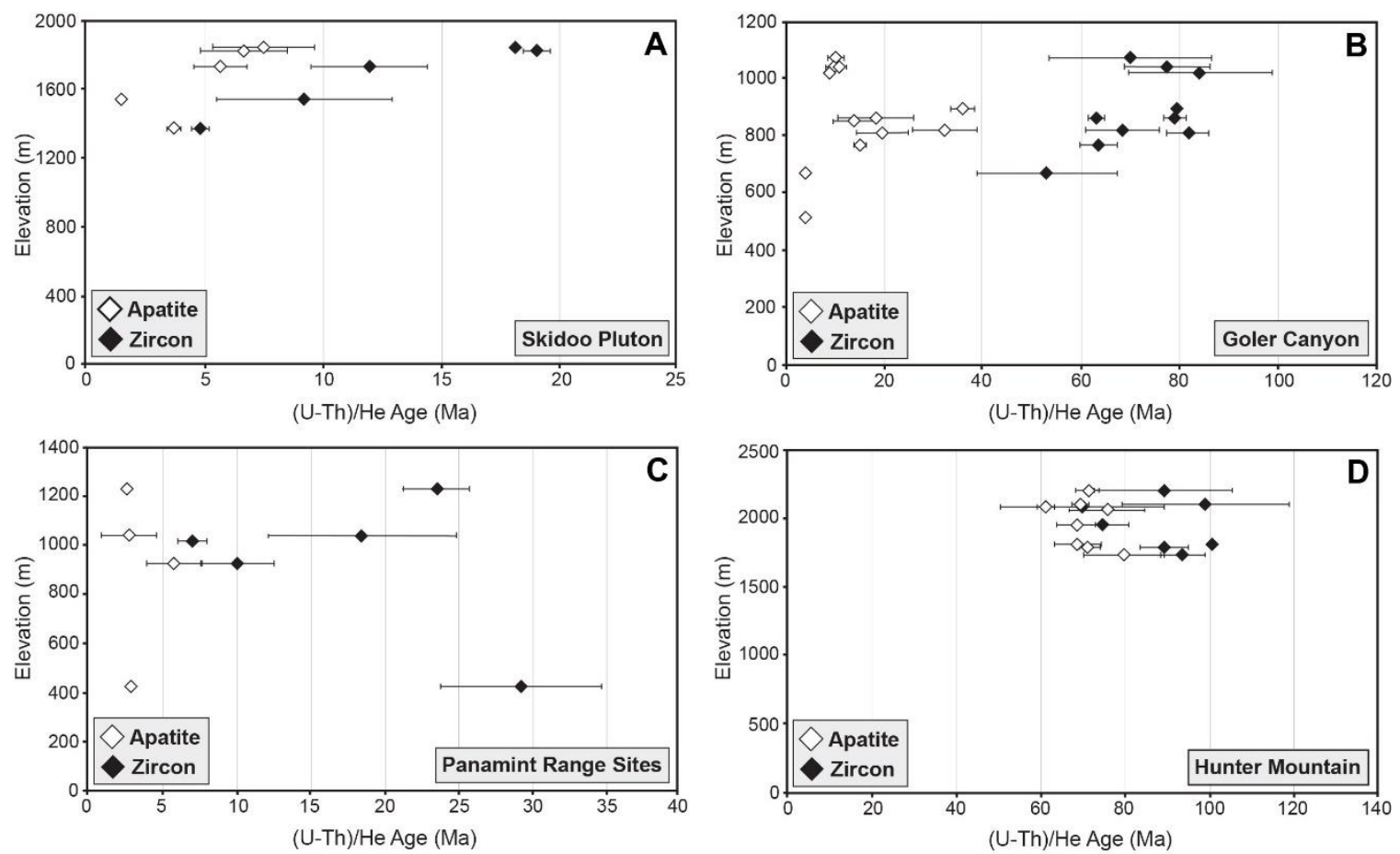

Figure 10. Plot of (U-Th)/He age versus elevation for samples from the (A) Skidoo Pluton, (B) Goler Canyon, (C) Panamint Range sites and (D) Hunter Mountain. A strong age-elevation relationship is seen for the Skidoo data and for the western part of the Goler Canyon transect while data from the Panamint Range and Hunter Mountain show no clear trend. 

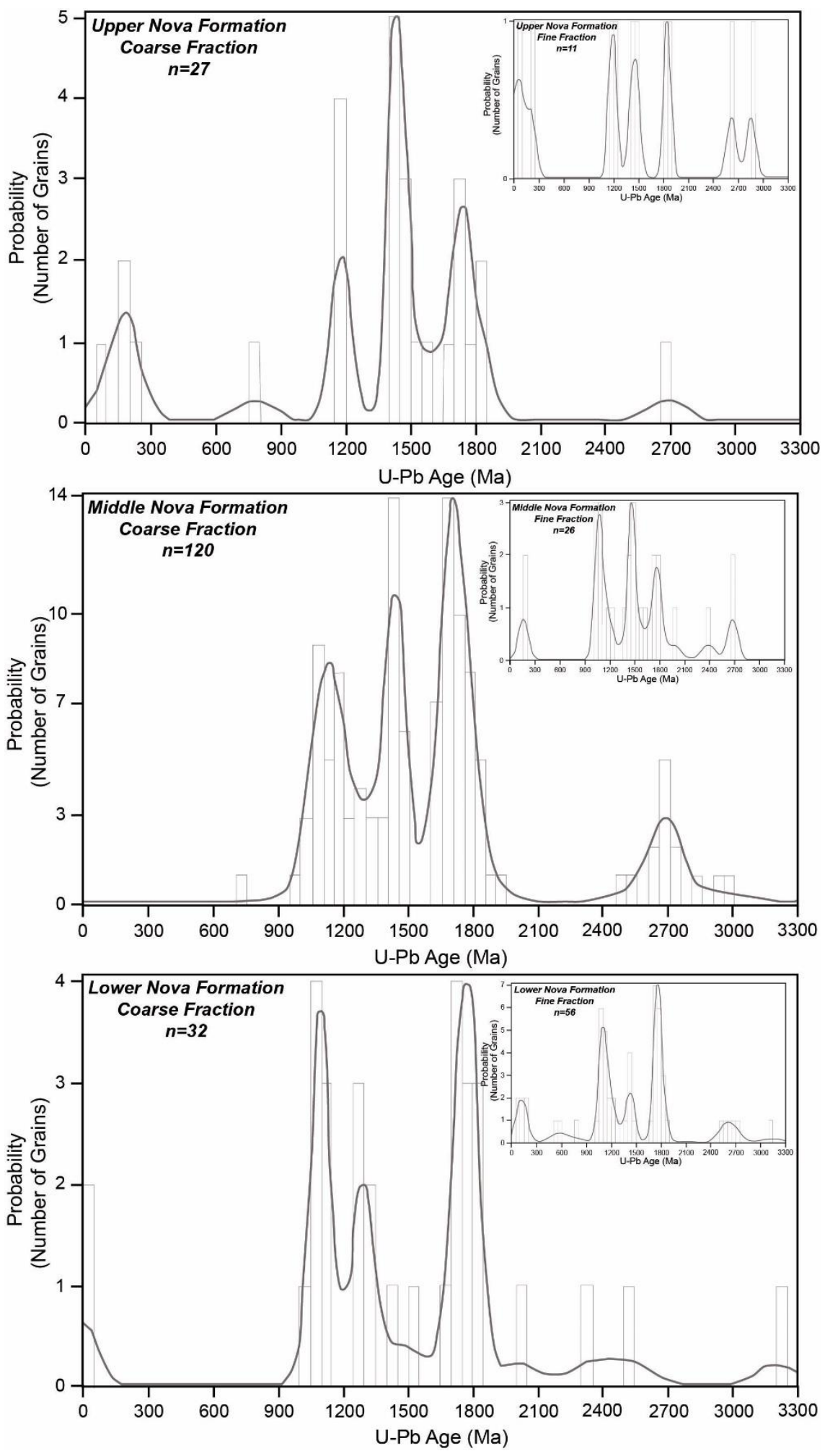

Figure 11. Kernel density estimation (KDE) plots of the detrital zircon U-Pb ages from the three major units of Nova Formation where the KDE curve represent the probability. 


\section{INTERPRETATION OF RESULTS}

\section{Skidoo Pluton}

\section{Paleodepth Reconstructions}

To evaluate the samples in more detail, we restored samples to their pre-extensional paleodepths (Fig. 12). Depths in the paleodepth reconstruction are referenced to the Paleogene (sub-Tertiary) unconformity. The unconformity is a regionally extensive boundary between Precambrian through Cretaceous rocks and Oligocene to Pliocene volcanic and sedimentary units and is commonly used as a datum for cross-section restorations (Fig. 9). In the northern Panamint Range, the unconformity separates Precambrian and Cambrian units from the east-tilted $\left(\sim 18^{\circ}\right)$ Miocene Trail Canyon volcanic sequence, exposed on the east side of the range. The reconstruction assumes that the range is a simple, tilted fault block (e.g., Armstrong et al., 2003) and adds $~ 580 \mathrm{~m}$ of volcanic overburden, established from a measured stratigraphic section in the southern part of the range (Andrew and Walker, 2009). This thickness estimate is similar to that obtained by Hodges and McKenna (1990) ( 500 m) in the central Panamint Range.

The resulting paleodepth reconstruction shows that, although the samples were collected from a transect spanning only $\sim 500 \mathrm{~m}$ of elevation $(1373-1842 \mathrm{~m})$, they capture a more than $6 \mathrm{~km}$ thick crustal section. The age versus paleodepth reconstruction contains two distinct period of cooling. Apatite He mean ages record continuous exhumation from $\sim 8 \mathrm{Ma}$ to $\sim 4 \mathrm{Ma}$ and increase in age with decreasing paleodepth. The exception is sample 19SP05, which is represented by a single date and therefore not included in our evaluation. 
Zircon He mean ages from the same samples range from $~ 19$ Ma to 5 Ma and also increase in age with decreasing paleodepth, defining a zircon He PRZ. The two structurally shallowest ages overlap within errors and suggest a period of rapid exhumation at $\sim 17-18$ Ma (Fig. 12).

The data can also be used to evaluate the late Miocene geothermal gradient. This is determined by identifying inflection points in age versus paleodepth trends that define the bounds (paleoisotherms) of the PRZ, following the methods outlined in Stockli et al., (2002). The estimated depth and uncertainties in the positions of the top $\left(\sim 130^{\circ} \mathrm{C}\right)$ and base $\left(\sim 190{ }^{\circ} \mathrm{C}\right)$ of the zircon $\mathrm{He}$ PRZ are shown in Fig. 12 . The position of $130^{\circ} \mathrm{C}$ isotherm is constrained between samples z19SP02 and z19SP03; whereas, the position of the 190 ${ }^{\circ} \mathrm{C}$ isotherm is constrained between samples z19SP04 and z19SP05. The maximum vertical difference between the top and base of the PRZ is $1.9 \mathrm{~km}$. There is $0.4 \mathrm{~km}$ of uncertainty in the position of the top of the PRZ; and $1 \mathrm{~km}$ of uncertainty in the base (Fig. 12: gray shaded areas). Assuming a mean surface temperature of $10 \pm 5^{\circ} \mathrm{C}$ and considering the different possible positions for the isotherms (Fig. 12) a Miocene geothermal gradient of $34 \pm 9^{\circ} \mathrm{C} / \mathrm{km}$ can be determined.

\section{Vertical Exhumation and Magnitude of Extension}

The thermochronology data may also be used to determine the magnitudes of vertical exhumation and horizontal extension, which can provide an independent test of displacement magnitudes from prior studies. Assuming a mean surface temperature of 10 ${ }^{\circ} \mathrm{C}$, the paleodepth reconstruction indicates that the northern Panamint Range has experienced at least $180{ }^{\circ} \mathrm{C}$ of cooling since at least the middle Miocene. Using our 
geothermal gradient $\left(34 \pm 9^{\circ} \mathrm{C} / \mathrm{km}\right)$, we estimate $4.2-7.2 \mathrm{~km}$ of vertical exhumation since 8 Ma. Based on the restored geometry of the PED ( $37^{\circ}$; Fig. 9) and basic trigonometry rules, this translates to $\sim 5.6-9.6 \mathrm{~km} \mathrm{E-W}$ extension. The apatite data also provide additional constraints on the rate of exhumation, suggesting at a rate of $2.5 \mathrm{~km} / \mathrm{Myr}$ from 8 to $4 \mathrm{Ma}$.

It is important to note that the geometry of the unconformity and variability in the dip of volcanic units above it introduce some uncertainty into the estimates described above. Analysis of the map data suggests that the dips vary by as much as 3 degrees. Higher or lower dips would shift the positions of samples in the paleodepth restoration and the total distance from the datum. Thus, factoring this source of uncertainty into our extension estimates suggest the net extension could be higher or lower by $\sim 11 \%$.

\section{Goler Canyon}

\section{Paleodepth Reconstruction}

To evaluate the samples from the Goler Canyon transect, we restored samples to their pre-extensional paleodepth using the same datum and overburden estimate as we did for the Skidoo pluton transect, described above (Fig. 13). The paleodepth reconstruction shows that, although the samples were collected from within 500 meters of elevation (515 $-1071 \mathrm{~m}$ ), they restore to a more than $2.5 \mathrm{~km}$ thick crustal section. The structurally lowest apatite samples (12GC13 and 12GC15) overlap in error and suggest rapid exhumation at

4 Ma. Apatite He mean ages then get progressively older with shallowing paleodepth, defining an apatite He PRZ (Fig. 13). However, above $1.5 \mathrm{~km}$ paleodepth samples become younger and the shallowest samples (12GC01, 12GC02, 12GC03 and 12GC04), within 400 meters of the unconformity, are invariant and record rapid cooling at 8 to $9 \mathrm{Ma}$. It should 
be noted that these ages coincide with the age of the Miocene Trail Canyon volcanic sequence ( 7.6 to $\sim 10.8 \mathrm{Ma}$ ) (McKenna and Hodges, 1990) and likely reflect thermal resetting tied to this phase of volcanism. Zircon He mean ages from the same samples document a period of cooling from 50-80 Ma. The structural shallowest samples, near the unconformity, also become younger and more dispersed, suggesting resetting tied to volcanism above the unconformity.

The (U-Th)/He data from the Goler Canyon transect can also be used to evaluate the pre-extensional geothermal gradient. Here we use the estimated depth and uncertainty in the position of the base $\left(\sim 80^{\circ} \mathrm{C}\right)$ of the apatite He PRZ. As shown in Fig. 13, the position of $80{ }^{\circ} \mathrm{C}$ isotherm is constrained between the samples $12 \mathrm{GCl} 10$ at $1.95 \mathrm{~km}$ depth and $12 \mathrm{GC} 13$ at $2.35 \mathrm{~km}$ depth. Assuming a mean surface temperature of $10{ }^{\circ} \mathrm{C} \pm 5$, this translates to a geothermal gradient of $33 \pm 4{ }^{\circ} \mathrm{C} / \mathrm{km}$ (Fig. 13). This estimate is similar to the one obtained from the Skiddo pluton transect and from published studies in the central Panamint Range and Black Mountains (Bidgoli et al., 2015).

\section{Vertical Exhumation and Magnitude of Extension}

Assuming a mean surface temperature of $10{ }^{\circ} \mathrm{C}$, the paleodepth reconstruction indicates that the southern Panamint Range has only experienced $70{ }^{\circ} \mathrm{C}$ of cooling in the Cenozoic. Using our estimated geothermal gradient, the data indicate that there has been 1.9.-2.4 km of vertical exhumation. However, our structurally lowest sample resides approximately $0.2 \mathrm{~km}$ below the $80{ }^{\circ} \mathrm{C}$ paleoisotherm, suggesting the total vertical exhumation is slightly higher $(\sim 2.1-2.6 \mathrm{~km})$. Using the restored geometry of the Emigrant detachment $\left(37^{\circ}\right)$, we estimate $2.7-3.4 \mathrm{~km}$ of east-west extension. Accounting for 
uncertainties in geometry of the unconformity, this estimate may be higher or lower by $\sim 6 \%$. 


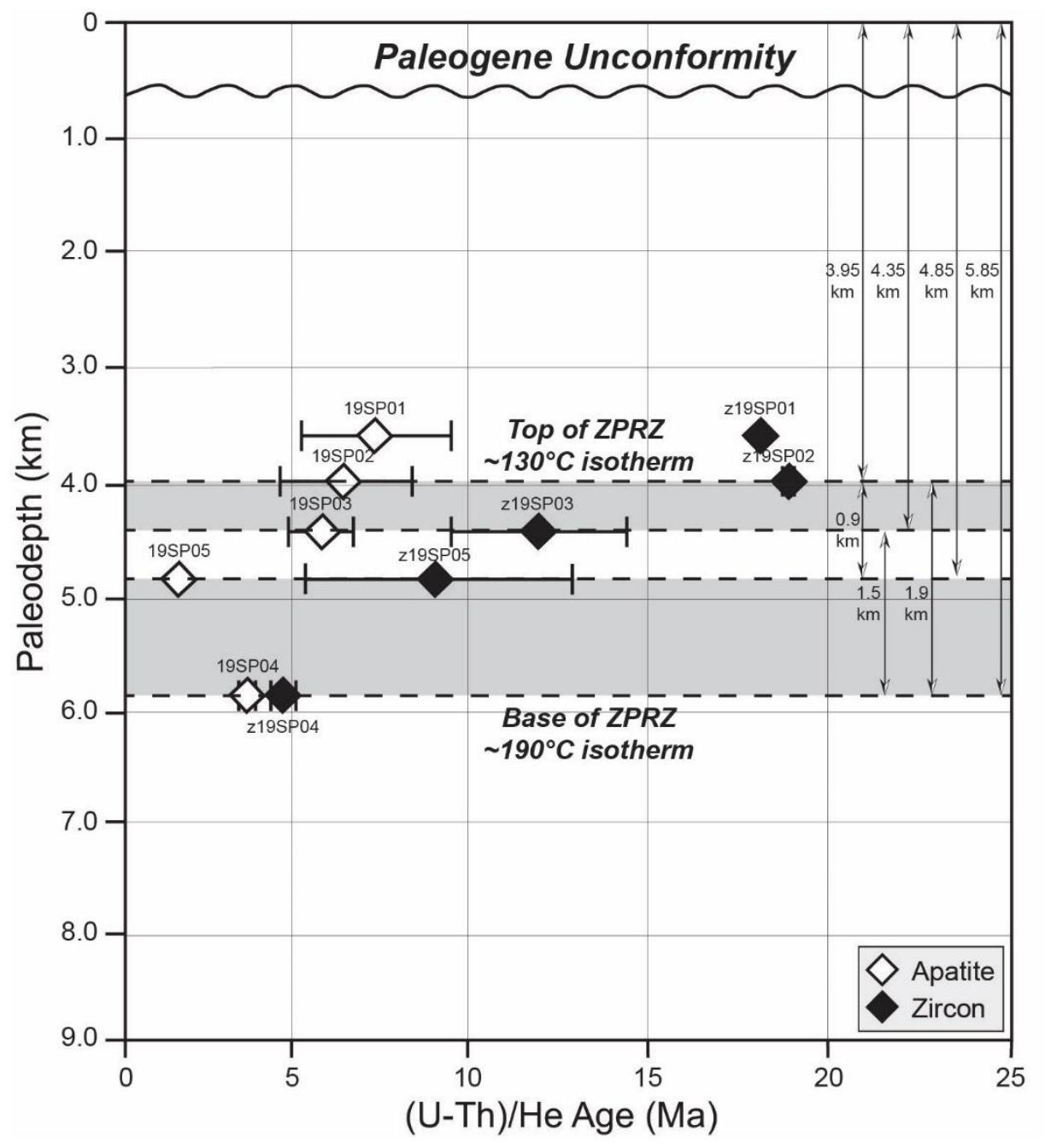

Figure 12. Paleodepth reconstruction of the Skidoo Pluton samples. Mean zircon and apatite (U-Th)/He ages from the footwall of the Panamint Emigrant detachment are plotted against distance from the Paleogene unconformity. Error bars show standard deviations $(1 \sigma)$. Gray areas correspond to the uncertainty in positions of the $\sim 130^{\circ} \mathrm{C}$ and $\sim 190^{\circ} \mathrm{C}$ isotherms. 


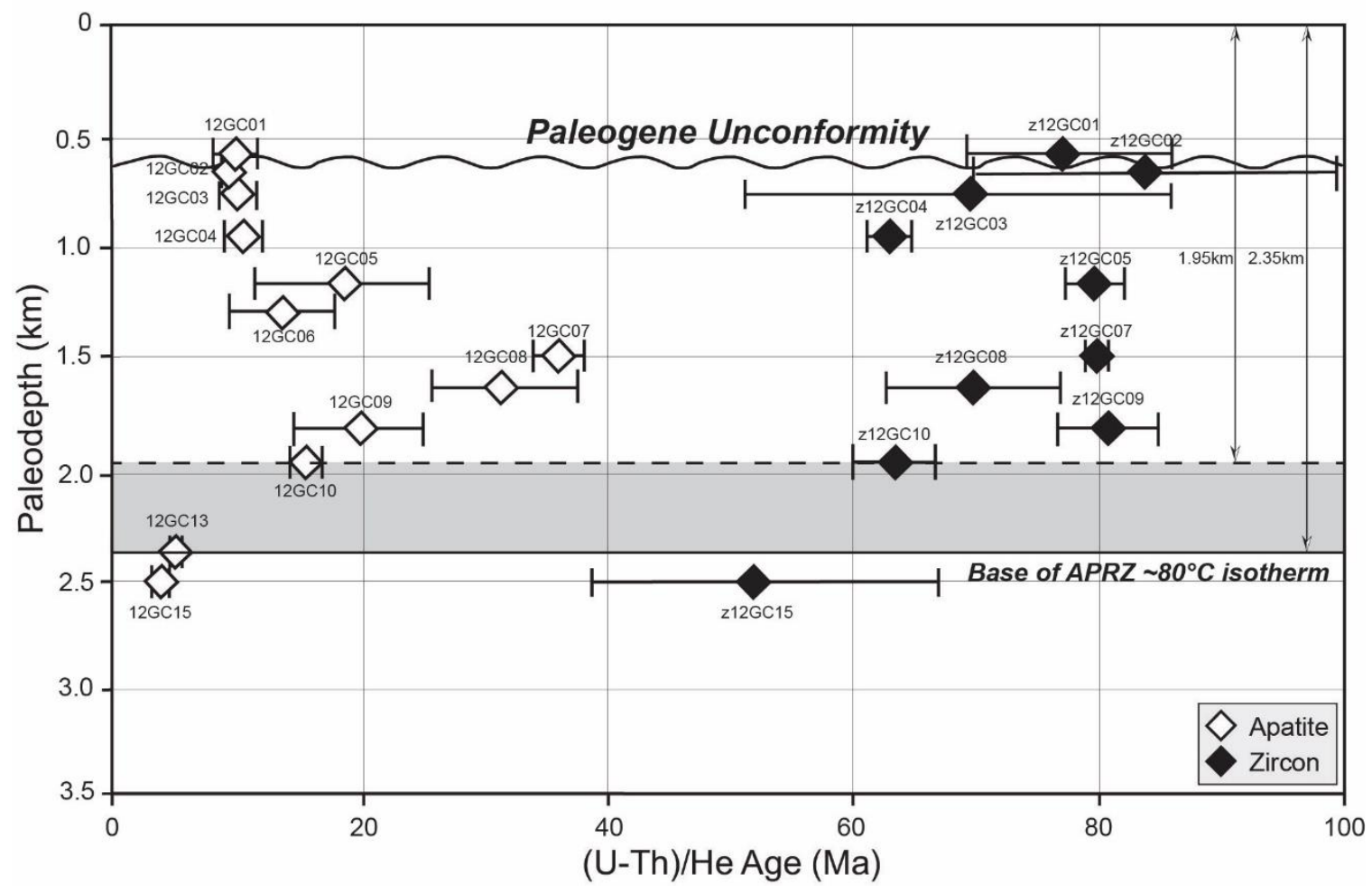

Figure 13. Paleodepth reconstruction from the Goler Canyon samples. Mean zircon and apatite (U-Th)/He ages from the footwall of the Emigrant detachment plotted against distance from the Paleogene unconformity. Error bars show standard deviations $(1 \sigma)$. Gray area corresponds to the uncertainty in position of the $\sim 80^{\circ} \mathrm{C}$ isotherm. 


\section{DISCUSSION}

\section{Spatial-Temporal Pattern of Strain}

The new data from the Panamint Range and the southern Cottonwood Mountains provides important constraints on the spatial-temporal pattern of strain and the evolution of faults in the region. At least four distinct periods exhumation are preserved in our data: (1) Late Cretaceous to Eocene exhumation in the Cottonwood Mountains and the southern Panamint Range; (2) middle to late Miocene exhumation in the northern Panamint Range; (3) Pliocene exhumation in the northern and southern part of the Panamint Range; and (4) latest Pliocene cooling at sites in the north-central and south-central Panamint Range.

The thermochronology data from the Hunter Mountain and the Goler Canyon transects document a major pulse of cooling in the Late Cretaceous to Eocene ( 80-50 Ma). In the Cottonwood Mountains, this event is recorded in both the zircon and apatite data, suggesting substantial cooling of the range at this time; however, the fault(s) responsible for this exhumation are not known. In the southern part of the range, zircon He ages record a similar cooling event. Eocene cooling is also recognized in data from the central Panamint Range (Bidgoli et al., 2015). Although the fault(s) responsible for this exhumation are not established, the Harrisburg detachment, exposed in the northern part of the range, is a likely candidate. The detachment is the oldest part of the Tucki Mountain detachment system (Wernicke et al., 1988; Snow and Wernicke, 1989). As pointed out by Andrew and Walker (2009), the fault is back-tilted $\left(16^{\circ} \mathrm{E}\right)$, suggesting it is older than other low-angle normal faults in the range, and its footwall is ductilely deformed. Late 
Cretaceous extensional deformation is also documented in the Funeral Mountains, east of Death Valley (DeWitt et al., 1988; Applegate et al. 1992; Applegate, 1994; Applegate and Hodges, 1995) and elsewhere in the region (see summary in Lee et al., 2009). The new data confirm that this episode of extension affected the study area and may have accommodated a significant portion of the strain prior to the middle Miocene.

Middle to late Miocene exhumation is preserved in our samples from the northern Panamint Range. Zircon He ages record exhumation in the footwall of the PED at $\sim 18 \mathrm{Ma}$ and from 8 to $4 \mathrm{Ma}$. The $18 \mathrm{Ma}$ exhumation is older than the $\sim 12 \mathrm{Ma}$ timing of fault initiation determined for the PED in the central Panamint Range and for the Slate Range detachment (Walker et al., 2014; Bidgoli et al., 2015). It is important to note that no middle to late Miocene exhumation is documented in the southern part of the range, in Goler Canyon. While it's possible that our sampling strategy missed this period of exhumation, a similar issue was noted for the northern Slate Range detachment (Walker et al., 2014) and suggests this is not an artifact of sample collection. These data may imply that faults of PED developed at different times and integrated over time.

Our apatite He mean ages from the northern part of the Panamint Range show that exhumation continued from $\sim 8$ Ma to $\sim 4$ Ma. Apatite He ages from the Goler Canyon record a rapid exhumation at $4 \mathrm{Ma}$. Rapid exhumation at $4 \mathrm{Ma}$ is also documented in the central Panamint Range (Bidgoli et al., 2015) and the northern Slate Range (Walker et al., 2014). These results are also confirmed by maximum depositional ages recovered from the lower (4.2 \pm 0.2 and $4.8 \pm 0.3 \mathrm{Ma})$ and upper $(3 \pm 0.2 \mathrm{Ma})$ Nova Formation samples, which suggest much of the basin fill was deposited at the same time as exhumation in the footwall of the PED. While it has been suggested that widespread exhumation at 4 Ma marks the 
transitions from Basin and Range extension to dextral transtension associated with the ECSZ, our apatite ages from sites near the intersections of the Manly Pass and Hunter Mountain faults with the PED, record a spatially restricted episode of cooling around 2.8 Ma. These late Pliocene ages are similar to published thermochronology data from the Inyo Mountains (AHe ages $2.8 \pm 0.7 \mathrm{Ma}$ ) that record renewed slip along the Eastern Inyo fault zone and the initiation of the Hunter Mountain fault zone (Lee et al., 2009). Together the new thermochronology data and published data suggests that the transition from the Basin and Range extension to the dextral transtension likely initiated around $4 \mathrm{Ma}$; however, the full integration of these fault systems may not have taken place until the latest Pliocene.

\section{Along-Strike Variability in Extension Magnitudes}

Extension magnitudes estimated from the thermochronology data in this study and other studies (Walker et al., 2014; Bidgoli et al., 2015) are variable depending on location and may have implications for the continuity and kinematics of faults in region. From north to south, extension estimates for the Panamint Range vary from 4.2-7.2 km in the Skidoo area to 10-15 km at Surprise and Pleasant Canyons (Bidgoli et al., 2015) to 1.9-2.4 km at Goler Canyon. These along-strike changes in extension likely reflect differences in the Miocene exhumation, which was concentrated in the northern and central part of the range, but absent in the Goler Canyon area. Similar along strike changes are documented for the Slate Range detachment, which in interpreted to have to formed a through-going detachment system with the PED in the Miocene (Andrew and Walker, 2009). Thermochronology data from the Slate Range suggest Miocene extension may have been concentrated in the central and southern parts of the range (Walker et al., 2015). The new 
data, however, suggest that the PED and Slate Range detachment may have been separate structures or at least segmented, with a displacement minimum located in the present-day southern Panamint and northern Slate ranges.

Along-strike changes in extension magnitude may also relate to the changing kinematics of faults in the region associated with the transition to dextral transtension at 4 Ma. Our lowest extension magnitudes come from the southern Panamint Range, where deformation appears to be Pliocene in age. The magnitude of Pliocene exhumation there is substantially lower than for the central Panamint Range. This variability may reflect a change in the kinematics of the fault, from dip-slip to strike-slip. This change would be consistent with the modern southern Panamint Valley fault, which is a strike-slip structure.

\section{Implications for Published Palinspastic Restorations}

The thermochronology data from this study provide an independent check on palinspastic reconstructions in the region. The thermochronology-based E-W extension estimate for the northern part of the Panamint Range, captured by the Skidoo pluton samples, is $\sim 5.6-9.6 \mathrm{~km}$ This extension magnitude is similar to the magnitude of the E-W extension $(7.6 \mathrm{~km})$ inferred from the displacement vector and overall reconstruction of Andrew and Walker (2009). However, our estimate is lower than the E-W extension magnitude (15.6 km) inferred from the restorations Serpa and Pavlis (1996) and McQuarrie and Wernicke (2005) based on reconstruction of a Cretaceous backfold across the Tucki Mountain detachment system (Wernicke et al., 1988; Snow and Wernicke, 1989). It's also substantially lower than the $27.7 \mathrm{~km}$ of extension inferred from reconstruction of the Mesozoic thrust belt structure by Snow and Wernicke (2000). 
While there is good agreement between our data and the reconstructions of Andrew and Walker (2009) for the northern Panamint Range and Cottonwood Mountains, our thermochronology-based extension estimate for the southern part of the range is significantly lower than what can be inferred from all of the published reconstructions. The E-W extension estimate, based on data from Goler Canyon, is $~ 2.7-3.4 \mathrm{~km}$, considering the restored geometry of the PED. However, Snow and Wernicke (2000) document a total displacement of $52.5 \mathrm{~km}$ between the Panamint and Argus range based on restoration of late Paleozoic and Mesozoic thrusts, of which $40.5 \mathrm{~km}$ reflects the E-W component. The update of this reconstruction, provided by McQuarrie and Wernicke (2005), also suggests a high amount of E-W extension $(23 \mathrm{~km})$ between these two ranges. Comparison of our data with the reconstruction of Serpa and Pavlis (1996) suggests that their reconstructed displacement and associated extension is also higher than our thermochronology-based estimate. Even estimates from Andrew and Walker (2009), with displacement vectors that are much shorter than the other reconstructions, requires $14.5 \mathrm{~km}$ of E-W extension between the south-central part of the Panamint Range and the Argus, based on the Miocene conglomerates at the inselbergs.

There are couple of possible explanations for differences between our horizontal extension magnitudes and those from previous studies. (1) Some of the extension in the palinspastic reconstructions may be older than the Miocene to Pliocene deformation of interest. Cooling ages from the Cottonwood Mountains and southern Panamint Range confirm a Cretaceous exhumation event in these ranges. This event resulted in substantial exhumation given the overlap in apatite and zircon (U-Th)/He ages in the Cottonwood Mountains. Thus, reconstructions that rely on Mesozoic strain markers may not be accurate 
because some component of that deformation being accounted for predates Miocene deformation. (2) While the orientation of the displacement vectors reported by Andrew and Walker (2009) are likely correct, the magnitude of their vector may be shorter. Their estimate relies on reconstruction of conglomerates, presently exposed as inselbergs across Panamint Valley, with their likely sources in the Panamint Range. Their estimates assume these conglomerates are mostly alluvial deposits, developed within a short distance $(<2$ $\mathrm{km}$ ) of the source. However, if these sediments are reworked or fluvial in origin, they may have been experienced larger primary transport distances, which would imply that the magnitude of tectonic displacement is shorter.

\section{Triassic to Latest Pliocene Fault Evolution}

Together, the new thermochronology data and published data suggest a complex evolution for faults in the study region. Figure 14 illustrates the major faults and how they have evolved with time, focusing on several important time intervals:

(1) Triassic to Eocene: During this time interval, the region was dominated by contraction and the development of the major thrust systems (e.g. Death Valley and East Sierra Thrust systems). In the study area, these are represented by the Panamint and Goldbug thrusts (Fig. 14). However, in the Late Cretaceous, exhumation also initiates and may be linked to regionally extensive syn-convergent extension (Wells and Hoisch, 2008). The Harrisburg fault in the northern part of the Panamint Range (Fig. 14) may be responsible for this period of exhumation (Wernicke et al., 1986; Hodges et al., 1989, 1990). 
(2) Middle Miocene ( 15 Ma): By $\sim 15 \mathrm{Ma}$, the region was dominated by Basin and Range extensional deformation along major low-angle fault systems (Holm et al., 1992; Holm and Dokka, 1993; Ferrill et al., 2010; Walker et al., 2014; Bidgoli et al., 2015). This period of deformation is reflected as exhumation along the PED, in the northern and central Panamint, and along the Slate Range detachment, in the Slate Range (Walker et al., 2014; Bidgoli et al., 2015). Although it has been suggested that these two faults constituted a continuous detachment system, thermochronology-based extension estimates suggest these faults may have been independent or at a minimum segmented, with a displacement minimum in the present-day southern Panamint Range and northern Slate Range (Fig. 14). Exhumation along these detachments was most rapid from approximately 8-4 Ma, which was likely the main phase of activity, tied to a major plate boundary reorganization (Walker et al., 2014; Bidgoli et al., 2015)

(3) Middle Pliocene ( 4 Ma): Published data and our results indicate a 4 Ma rapid exhumation event. A major reorganization of the faults west of Death Valley at this time has been linked to the $\sim 4 \mathrm{Ma}$ delamination of mantle lithosphere in the southern Sierra Nevada (Ducea and Saleeby, 1998; Bidgoli et al., 2015). With this event, the major fault systems become more fragmented than at Miocene time and the style of deformation changes. In the southern part of the Panamint Range, deformation is predominantly strike-slip, however, important extensional structures such as the Searles Valley fault still exist (Fig. 14). The PED is still active, though, most of the strain is accommodated in the northern part of the range, along the 
Towne Pass fault. In addition, linkages develop between the Searles Valley-Manly Pass faults and the PED, and the PED and Hunter Mountain fault zone.

(4) Late Pliocene ( 2.8 Ma): The main event during the end of the Pliocene is the integration of the major fault systems in the region. To the south, strain is taken up on the dominantly dip-slip Searles Valley and Manly Pass faults, which then intersect and transfer slip to the Panamint Valley fault. South of this intersection, the fault is primarily strike-slip. To the north, principally dip-slip motion on the Panamint Valley fault in transferred to the strike-slip Hunter Mountain fault zone, shifting strain onto the East Inyo fault zone in the Saline Valley. The modern system of faults appears to mirror this latest Pliocene framework. 


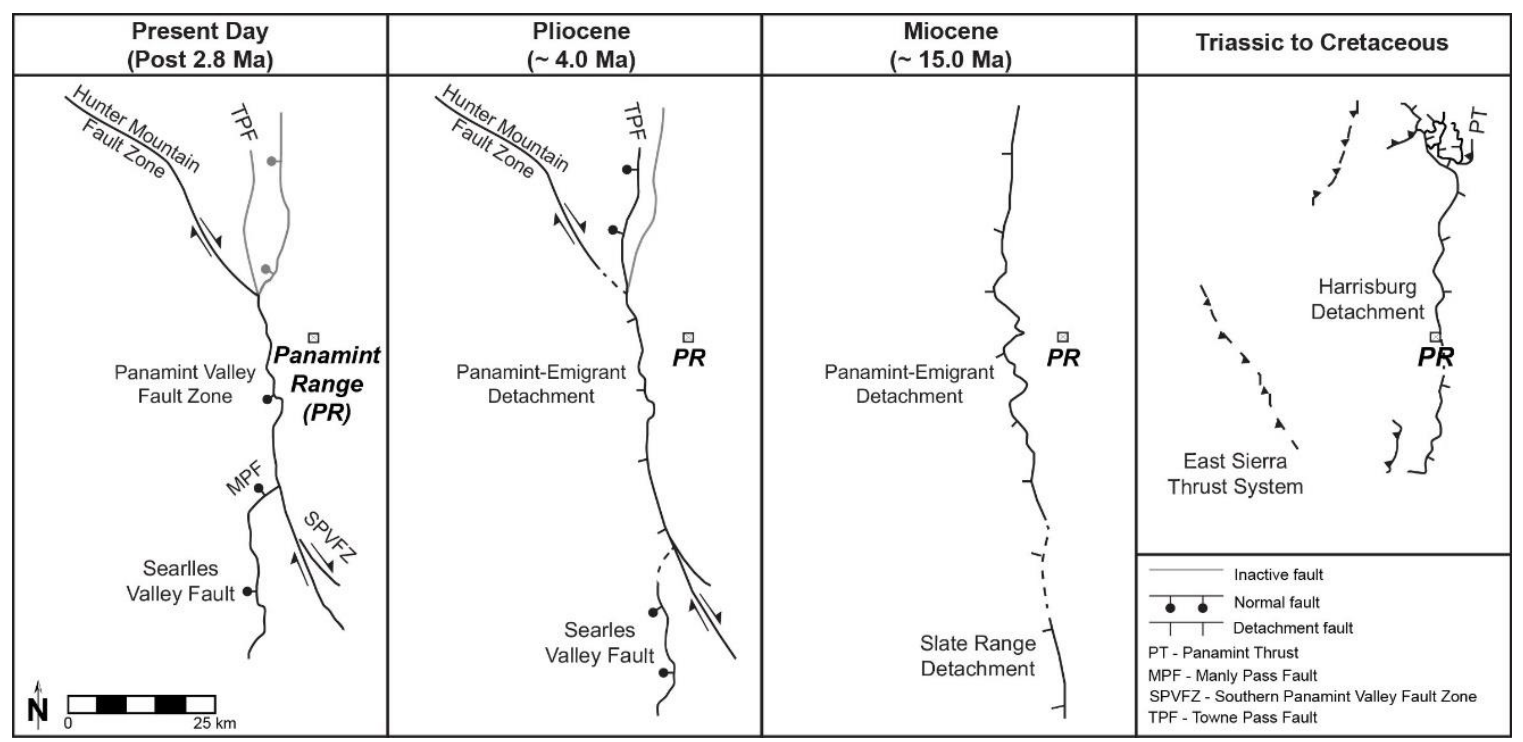

Figure 14. Schematic diagrams showing the evolution of the major fault systems with respect to the Panamint Range from Triassic to present. Dash lines between Hunter Mountain fault zone and Panamint-Emigrant detachment and Searles Valley fault and Panamint-Emigrant detachment represent the future linkages (faults after Andrew and Walker, 2009). 


\section{CONCLUSIONS}

This research reconstructed space-time strain paths of the Panamint and Cottonwood mountains, west of Death Valley, using bedrock (U-Th)/He thermochronology and detrital $\mathrm{U}-\mathrm{Pb}$ geochronology. The thermochronology data were evaluated using new geologic cross-sections and published fault timing data from the region to determine the history extensional and strike-slip deformation and to provide an independent check on published restorations.

The new data suggest the study area was affected by at least four distinct periods exhumation and cooling that relate to the structural evolution of faults in the region. (1) Late Cretaceous to Eocene exhumation in the Cottonwood Mountains and the southern Panamint Range was of fairly significant magnitude, given resetting of both zircon and apatite in samples from the Hunter Mountain Batholith. In the Panamint Range, this period of exhumation was likely accommodated by the Harrisburg fault, the oldest structure of the Tucki Mountain detachment system. (2) Middle to late Miocene exhumation is documented by both zircon and apatite data from the Skidoo pluton and appears to be restricted to the northern and central Panamint range. The lack of exhumation in the southern part of the range suggests a displacement minimum along PED near its linkage with the Slate Range detachment. (3) AHe data from the northern and southern Panamint Range document rapid exhumation in the footwall of the PED at $4 \mathrm{Ma}$, also confirmed by new maximum depositional ages for the lower and upper Nova Formation. This timing documented for many faults west of Death Valley and is interpreted to record the inception

of the ECSZ. (4) Latest Pliocene cooling is documented at sites in the north-central and 
south-central Panamint Range, near the intersections of the Manly Pass and Hunter Mountain faults. At these sites, the PED records exhumation at $2.8 \mathrm{Ma}$, similar to published data from the Inyo Mountains (Lee et al., 2009). The results suggest that while the transition to dextral transtension may have started at around $4 \mathrm{Ma}$, full integration of the fault systems in the region may not have occurred until the latest Pliocene.

Lastly, the thermochronology data provide important constraints on the validity of published palinspastic restoration of Cenozoic extension and transtension. Thermochronology-based extension estimates suggest that the magnitudes of the displacement used in most models (e.g. Serpa and Pavlis, 1996; Snow and Wernicke, 2000; Wernicke and McQuarrie, 2005) are too large, particularly restorations that use preCenozoic structures as strain markers. These restorations do not account for Late Cretaceous to Eocene extension, which may have taken up a significant portion of premiddle Miocene of strain. 


\section{REFERENCES}

Andersen, T., 2005, Detrital zircons as tracers of sedimentary provenance: limiting conditions from statistics and numerical simulation. Chem. Geol. 216 (3-4), 249-270.

Andrew, J. E. (2018). Geologic Map of southern Panamint Valley, southern Panamint Range and central Slate Range, California [Map].

Andrew, J.E., 2002, The Mesozoic and Tertiary tectonics of the Panamint Range and Quail Mountains, California [Ph.D. thesis]: Lawrence, University of Kansas, and 154p.

Andrew, J.E., and Walker, J.D., 2009, Reconstructing Cenozoic deformation in the Panamint Valley region, eastern California, with implications for timing and magnitude of faulting in parts of the Central Basin and Range: Geosphere, v. 5, p. 172-198.

Atwater, T., 1970, Implications of plate tectonics for the Cenozoic tectonic evolution of western North America: Bulletin of the Geological Society of America, v. 81, p. 3513-3536.

Atwater, T., and Stock, J., 1998, Pacific-North America plate tectonics of the Neogene southwestern United States: An update: International Geological Review, v. 40, p. 375-402.

Applegate, J.D.R., and Hodges, K.V., 1995, Mesozoic and Cenozoic extension recorded by metamorphic rocks in the Funeral Mountains, California: Geological Society of America Bulletin, v. 107, p. 1063- 1076, doi: 10.1130/0016-7606(1995)107<1063: MACERB>2.3.CO;2.

Applegate, J.D.R., Walker, J.D., and Hodges, K.V., 1992, Late Cretaceous extensional unroofing in the Funeral Mountains metamorphic core complex, California: Geology, v. 20 , p. $519-522$.

Bartley, J.M., Glazner, A.F., Coleman, D.S. Kylander-Clark, A., Mapes, R., and Friedrich, A.M., 2007, Large Laramide dextral offset across Owens Valley, California, and its possible relation to tectonic unroofing of the southern Sierra Nevada, in Till, A.B., Roeske, S.M., Sample, J.C., and Foster, D.A., eds., Exhumation Associated With Continental Strike-Slip Fault Systems: Geological Society of American Special Paper 434, p.129-148.

Bellier, O., and Zoback, M.L., 1995, Recent state of stress change in the Walker Lane zone, western Basin and Range Province, United States: Tectonics, v. 14, p. 564-593.

Benson, L.V., Currey, D.R., Dorn, R.I., Lajoie, K.R.,Oviatt, C.G., Robinson, S.W., Smith, G.I., and Stine,S., 1990, Chronology of expansion and contraction offour Great Basin lake systems during the past 35,000 years: Palaeogeography, Palaeoclimatology, Palaeoecology, v. 78, p. 241-286, doi: 10.1016/0031-0182(90)90217-U. 
Bidgoli, T.S., Amir, E., Walker, J.D., Stockli, D.F., Andrew, J.E., and Caskey, J.S., 2015, Low-temperature thermochronology of the Black and Panamint mountains, Death Valley, CA: Implications for geodynamic controls on Cenozoic intraplate strain, doi: 10.1130/L406.1.

Bidgoli, T.S., 2014, Low-temperature thermochronometric constraints on Cenozoic intraplate deformation in the central Basin and Range [Ph.D. dissertation]: Lawrence, Kansas, University of Kansas.

Burchfiel, B.C., Chen Zhialang, Hodges, K. V., Liu Yuping, Royden, L. H., Deng Changrong, and Xu Jiene, 1992, The South Tibetan detachment system, Himalayan Orogen: Extension contemporaneous with and parallel to shortening in a collisional mountain belt: Geological Society of America Special Paper 269.

Burchfiel, B. C., Hamill, G. S., \& Wilhelms, D. E., 1983, Structural geology of the Montgomery Mountains and the northern half of the Nopah and Resting Spring Ranges, Nevada and California. Geological Society of America Bulletin, 94(11), 1359. doi:10.1130/0016-7606(1983)942.0.co;2.

Burchfiel, B.C., Hodges, K.V., and Royden, L.H., 1987, Geology of Panamint ValleySaline Valley pull-apart system, California; palinspastic evidence for low-angle geometry of a Neogene range-bounding fault: Journal of Geophysical Research, v. 92 , p. $10,422-10,426$.

Cemen, I., R. Drake, and L.A. Wright, Stratigraphy and chronology of the Tertiary sedimentary and volcanic units at the southern end of the Funeral Mountains, Death Valley region, California, in Geology of Selected Areas in the Western Mojave Desert and Southern Great Basin, California, edited by Cooper et al., pp. 77-87, Death Valley Publishing Company, Shoshone, Calif., 1982.

Chapman, A.D., Saleeby, J.B., Wood, D.J., Piasecki, A., Kidder, S., Ducea, M.N., and Farley, K.A., 2012, Late Cretaceous gravitational collapse of the southern Sierra Nevada batholith, California: Geosphere, v. 8, p. 314-341.

Chen, J. H., \& Moore, J. G., 1982, Uranium-lead isotopic ages from the Sierra Nevada Batholith, California. Journal of Geophysical Research: Solid Earth, 87(B6), 47614784. doi:10.1029/jb087ib06p04761.

Cichanski, M., 2000, Low-angle, range-flank faults in the Panamint, Inyo, and Slate ranges, California: Implications for recent tectonics of the Death Valley region. Geological Society of America Bulletin, 112(6), 871-883. doi:10.1130/00167606(2000)1122.0.co;2.

DeCelles, P.G., 2004, Late Jurassic to Eocene evolution of the Cordilleran thrust belt and foreland basin system, western U.S.A.: American Journal of Science, v. 304, p. 105-168, https://doi.org/10.2475/ajs.304.2.105.

Dickinson, W. R., \& Gehrels, G. E., 2009, Use of U-Pb ages of detrital zircons to infer maximum depositional ages of strata: A test against a Colorado Plateau Mesozoic 
database. Earth and Planetary Science Letters, 288(1-2), 115-125. doi:10.1016/j.epsl.2009.09.013

Dickinson, W.R., Gehrels, G.E., 2010, Insights into North American Paleogeography and Paleotectonics from U-Pb ages of detrital zircons in Mesozoic strata of the Colorado Plateau, USA: International Journal of Earth Sciences, v. 99, p. 1247-1265.

Dunne, G.C., and Walker, J.D., 1993, Age of Jurassic volcanism and tectonism, southern Owens Valley region, east-central California: Geological Society of America Bulletin, v. 105, p. 1223-1230.

Dunne, G.C., and Walker, J.D., 2004, Structure and evolution of the East Sierran thrust system, east central California: Tectonics, v. 23, p. TC4012, 1-23.

Dodson, M. H., 1973, Closure temperatures in cooling geological and petrological systems, Contributions to Mineralogy and Petrology, v. 40, p. 259-274.

Dokka, R.K., and Travis, C.J., 1990a, Late Cenozoic strike-slip faulting in the Mojave Desert: Tectonics, v. 9, p. 311-340, doi: 10.1029/TC009i002p00311.

Dokka, R.K., and Travis, C.J., 1990b, Role of the Eastern California Shear Zone in accommodating Pacifi c-North American plate motion: Geophysical Research Letters, v. 17, p. 1323-1326, doi: 10.1029/GL017i009p01323.

Dokka, R.K., and Travis, C.J., 1990, Role of the eastern California shear zone in accommodating Pacific-North American plate motion: Geophysical Research Letters, v. 17, p. 1323-1326.

Ehlers, T. A., \& Chapman, D. S.,1999, Normal fault thermal regimes: Conductive and hydrothermal heat transfer surrounding the Wasatch fault, Utah. Tectonophysics, 312(2-4), 217-234. doi:10.1016/s0040-1951(99)00203-6.

Ehlers, T.A., 2005, Crustal thermal processes and the inter-pretation of thermochronometer data, in Reiners, P.W., and Ehlers, T.A., eds., Low-temperature thermochro-nology: Reviews in Mineralogy and Geochemistry Volume 58, p. 315-350, doi: 10 .2138 /rmg .2005 .58.12.

Ehlers, T.A., Willett, S.D., Armstrong, P.A., and Chapman, D.S., 2003, Exhumation of the Central Wasatch Moun-tains, Utah: 2. Thermo-kinematics of exhumation, ero-sion and thermochronometer interpretation: Journal of Geophysical Research, v. 108, 2173, doi: 10.1029 /2001JB001723.

Evans, S. L., Styron, R. H., Soest, M. C., Hodges, K. V., \& Hanson, A. D. (2015). Zircon and apatite (U-Th)/He evidence for Paleogene and Neogene extension in the Southern Snake Range, Nevada, USA. Tectonics, 34(10), 2142-2164. doi:10.1002/2015tc003913

Farley, K. A., 2002,18. (U-Th)/He Dating: Techniques, Calibrations, and Applications. Noble Gases, 819-846. doi:10.1515/9781501509056-020. 
Farley, K.A., 2000, Helium diffusion from apatite: General behavior as illustrated by Durango fluorapatite: Journal of Geophysical Research: v. 105, p. 2903-2914, doi:10.1029/1999JB900348.

Farley, K.A., and Stockli, D.F., 2002, (U-Th)/ He dating of phosphates; apatite, monazite, and xenotime, inKohn, M.J., Rakovan, J., and Hughes, J.M., eds., Phosphates; geochemical,geobiological, and materials importance., Mineralogical Society of America and Geochemical Society. Washington, DC, United States.

Farley, K.A., Wolf, R.A., and Silver, L.T., 1996, The effects of long alpha-stopping distances on (U-Th)/ He ages: Geochimica et Cosmochimica Acta, v. 60, p. 42234229.

Feng, R., Machado, N., \& Ludden, J., 1993, Lead geochronology of zircon by LaserProbe-inductively coupled plasma mass spectrometry (LP-ICPMS). Geochimica Et Cosmochimica Acta, 57(14), 3479-3486. doi:10.1016/00167037(93)90553-9.

Fitzgerald P.G., Fryxell J.E., Wernicke B.P., 1991, Miocene crustal extension and uplift in southeastern Nevada: Constraints from fission track analysis. Geology 19:10131016.

Fitzgerald P.G., Gleadow A.J.W/, 1988, Fission track geochronology, tectonics and structure of the Transantarctic Mountains in Northern Victoria Land, Antarctica. Isotope Geosci 73:169-198.

Fitzgerald, P. G., Sandiford, M., Barrett, P. J., \& Gleadow, A. J., 1986, Asymmetric extension associated with uplift and subsidence in the Transantarctic Mountains and Ross Embayment. Earth and Planetary Science Letters, 81(1), 67-78. doi:10.1016/0012-821x(86)90101-9.

Flowers R.M., Ketcham R.A., Shuster D.L., Farley K.A., 2009, Apatite (U-Th)/He thermochronometry using a radiation damage accumulation and annealing model, Geochimica et Cosmochimica Acta, v. 73, p. 2347-2365.

Foster D.A., Gleadow A.J.W., Reynolds S.J., Fitzgerald P.G., 1993, The denudation of metamorphic core complexes and the reconstruction of the Transition Zone, westcentral Arizona: constraints from apatite fi ssion-track thermochronology. J Geophys Res 98:2167-2185.

Foster, D.A., and John, B.E., 1999, Quantifying tectonic exhumation in an extensional orogen with thermo-chronology: Examples from the southern Basin and Range Province, in Ring, U., et al., eds., Exhumation processes: Normal faulting, ductile flow and erosion: Geological Society, London, Special Publication 154, p. 343-364, doi: 10 .1144/GSL .SP .1999.154 .01 .16.

Fryer, B. J., Jackson, S. E., \& Longerich, H. P. (1993). The application of laser ablation microprobe-inductively coupled plasma-mass spectrometry (LAM-ICP-MS) to in 
situ (U)-Pb geochronology. Chemical Geology, 109(1-4), 1-8. doi:10.1016/00092541(93)90058-q.

Giallorenzo, M., Wells, M., Yonkee, W., Stockli, D., \& Wernicke, B. (2017). Timing of exhumation, Wheeler Pass thrust sheet, southern Nevada and California: Late Jurassic to middle Cretaceous evolution of the southern Sevier fold-and-thrust belt. GSA Bulletin, 130(3-4), 558-579. doi:10.1130/b31777.1.

Glazner, A.F., Lee, J. Bartley, J.M., Coleman, D.S., Kylander-Clark, A., Greene, D.C., and Le, K., 2005, Large dextral offset across Owens Valley, California from 148 Ma to 1872 A.D., in Stevens, C. and Cooper, J., eds., Western Great Basin Geology: Pacific Section, SEPM, v. 99, p. 1-35.

Guenthner, W., Reiners, P.W., Ketcham, R.A., Nasdala, L., and Giester, G., 2013, Helium diffusion in natural zircon: Radiation damage, anisotropy, and the interpretation of zircon (U-Th)/He thermochronology: American Journal of Science, v. 313, p. 145198.

Guenthner, W. R., P. W. Reiners, P. G. DeCelles, and J. Kendall (2015), Sevier belt exhumation in central Utah constrained from complex zircon (U-Th)/He data sets: Radiation damage and He inheritance effects on partially reset detrital zircons, Geol. Soc. Am. Bull.,127(3-4), 323-348,doi:10.1130/B31032.1.

Gulliver, R. M. 1976. Structural analysis of Paleozoic rocks in the Talc City Hills, Inyo County, California, Santa Barbara: University of California. Unpubl. M. S. thesis, $105 \mathrm{p}$.

Harrison, T.M. and Zeitler, P.K., 2005, Fundamentals of noble gas thermochronometry in Reiners, P.W. and Ehlers T.A., eds., Low Temperature Thermochronology: Techniques, Interpretations, and Applications: Mineralogical Society of America, Reviews in Mineralogy and Geochemistry, v. 58, p. 123-149.

Hart, N. R., Stockli, D. F., Lavier, L. L., Hayman, N. W., 2017, Thermal evolution of a hyperextended rift basin, Mauléon Basin, western Pyrenees. Tectonics, 36(6), 1103-1128. doi:10.1002/2016tc004365.

Henry, C.D., Faulds, J.E., and dePolo, C.M., 2007, Geometry and timing of strike-slip and normal faults in the northern Walker Lane, northwestern Nevada and northeastern California: Strain partitioning or sequential extensional and strike-slip deformation?, in Till, A.B., Roeske, S.M., Sample, J.C., and Foster, D.A., eds., Exhumation Associated with Continental Strike-Slip Fault Systems: Boulder, CO, Geological Society of America Special Paper 434, p. 59-79, doi: 10.1130/ 2007.2434(04).

Hirata, T., \& Nesbitt, R. W. (1995). U-Pb isotope geochronology of zircon: Evaluation of the laser probe-inductively coupled plasma mass spectrometry technique. Geochimica Et Cosmochimica Acta, 59(12), 2491-2500. doi:10.1016/00167037(95)00144-1. 
Hodges, K.V., Walker, J.D., and Wernicke, B.P., 1987, Footwall structural evolution of the Tucki Mountain detachment system, Death Valley region, southeastern California, in Coward, M.P., et al., eds., Continental extensional tectonics: Geological Society of London Special Publication 28, p. 393-408.

Hodges, K.V., McKenna, L.W., Stock, J., Knapp, J., Page, L., Sternlof, K., Wuest, G., and Walker, J.D., 1989, Evolution of extensional basins and basin and range topography west of Death Valley, California: Tectonics, v. 8, p. 453-467.

Hodges, K.V., McKenna, L.W., and Harding, M.B., 1990, Structural unroofing of the central Panamint Mountains, Death Valley region, southeastern California, in Wernicke, B.P., ed., Basin and Range extensional tectonics near the latitude of Las Vegas, Nevada: Geological Society of America Memoir 176, p. 377-390.

Holm, D.K., Snow, J.K., and Lux, D.R., 1992, Thermal and barometric constraints on the intrusive and unroofing history of the Black Mountains-Implications for timing, initial dip, and kinematics of detachment faulting in the Death Valley region, California: Tectonics, v. 11, p. 507-522.

House, M.A., Farley, K.A., and Kohn, B.P., 1999, An empirical test of helium diffusion in apatite; borehole data from the Otway Basin, Australia: Earth and Planetary Science Letters, v. 170, p. 463-474.

Horn, I., Rudnick, R. L., \& Mcdonough, W. F., 2000, Precise elemental and isotope ratio determination by simultaneous solution nebulization and laser ablation-ICP-MS: Application to U-Pb geochronology. Chemical Geology, 164(3-4), 281-301. doi:10.1016/s0009-2541(99)00168-0.

Hunt, C.B., and Mabey, D.R., 1966, Stratigraphy and Structure, Death Valley, California: U.S. Geological Survey Professional Paper 494A, 162 p.

Hurley, P.M., 1952, Alpha ionization damage as a cause of low helium ratios: Transactions of the American Geophysical Union, v. 33, p. 174-183.

Jackson, S.E., Pearson, N.J., Griffin, W.L., Belousova, E.A., 2004.The application of laser ablation-inductively coupled plasma-mass spectrometry to in situ $\mathrm{U}-\mathrm{Pb}$ zircon geochronology. Chem. Geol. 211 (1-2), 47-69.

Jaffey, A.H., Flynn, K.F., Glendenin, L.E., Bentley, W.C., Essling, A.M., 1971, Precision measurement of half-lives and specific activities of ${ }^{235} \mathrm{U}$ and ${ }^{238} \mathrm{U}$ : Phys. Rev. 4, 1889-1906.

John B.E., Foster D.A., 1993, Structural and thermal constraints on the initiation angle of detachment faulting in the southern Basin and Range; the Chemehuevi Mountains case study. Geol Soc Am Bull 105:10911108.

Jones, C.H., Farmer, G.L., and Unruh, J., 2004, Tectonics of Pliocene removal of lithosphere of the Sierra Nevada, California: Geological Society of America Bulletin, v. 116 , p. $1408-1422$. 
Ketcham R.A., 1996, Distribution of heat-producing elements in the upper and middle crust of southern and west central Arizona: Evidence from the core complexes. J Geophys Res 101:13,611-13,632.

Kirby, E., Walker, J.D., Gosse, J., and McDonald, E., 2004,Late Quaternary-Recent slip on a low-angle normal fault: Inferences from alluvial deposits along the Panamint Valley fault system: Geological Society of America Abstracts with Programs, v. 36, no. 5 , p. 547.

Kosler, J., \& Sylvester, P. J. (2003). 9. Present Trends and the Future of Zircon in Geochronology: Laser Ablation ICPMS. Zircon, 243-276.

doi:10.1515/9781501509322-012.

Kosler, J., Tubrett, M. N., \& Sylvester, P. J., 2001, Application of Laser Ablation ICPMS to U-Th-Pb Dating of Monazite. Geostandards and Geoanalytical Research, 25(2-3), 375-386. doi:10.1111/j.1751-908x.2001.tb00612.x.

Labotka, T. C., Albee, A. L., Lanphere, M. A., \& Mcdowell, S. D., 1980, Stratigraphy, Structure, and Metamorphism in the Central Panamint Mountains (Telescope Peak Quadrangle), Death Valley Area, California. GSA Bulletin, 91(3_Part_II), 843-933. doi:10.1130/gsab-p2-91-843.

Labotka, T. C., Warasila, R. L., \& Spangler, R. R., 1985, Polymetamorphism in the Panamint Mountains, California: A39AR-40AR study. Journal of Geophysical Research, 90(B12), 10359. doi:10.1029/jb090ib12p10359.

Le Pourhiet, L., Gurnis, M., \& Saleeby, J., 2006, Mantle instability beneath the Sierra Nevada Mountains in California and Death Valley extension. Earth and Planetary Science Letters, 251(1-2), 104-119. doi:10.1016/j.epsl.2006.08.028.

Lee, J., Stockli, D.F., Owen, L.A., Finkel, R.C., and Kislitsyn, R., 2009, Exhumation of the Inyo Mountains, California: Implicationsfor the timing of extension along the western boundary of the Basinand Range Province and distribution of dextral fault slip ratesacross the eastern California shear zone: Tectonics, v. 28, TC1001, doi:10.1029/2008TC002295.

Li, X.H., 2000, Cretaceous magmatism and lithospheric extension in Southeast China.J. Asian Earth Sci. 18, 293-305.https://doi.org/10.1016/S1367-9120(99)00060-7.

Maerten, L., Willemse, E.J.M., Pollard, D.D., and Rawn-sley, K.D., 1999, Slip distribution on intersecting nor-mal faults: Journal of Structural Geology, v. 21,p. 259-271, doi: 10.1016/S0191-8141(98)00122-9.

McAllister, J.F.,1971, Preliminary geologic map of the Funeral Mountains in the Ryan quadrangle, Death Valley region, Inyo County, California, U.S.Geological Survey Open File Map.

McKenna, L.W., and Hodges, K.V., 1990, Constraints on the kinematics and timing of late Miocene-Recent exten-sion between the Panamint and Black Mountains, 
southeastern California, in Wernicke, B.P., ed., Basin and Range Extensional Tectonics near the Latitude of Las Vegas, Nevada: Geological Society of America Memoir 176, p. 363-376, doi:10.1130/MEM176-p363.

McQuarrie, N. and Wernicke, B., 2005, An animated tectonic reconstruction of southwestern North America since 36 Ma: Geosphere, v. 1, p. 147-172.

Miller, E.L., Dumitru, T.A., Brown, R., and Gans, B., 1999, Rapid Miocene slip on the Snake Range-Deep Creek Range fault system, east-central Nevada: Geological Society of America Bulletin, v. 111, p. 886-905, doi: 10 .1130/0016-7606 (1999)111<0886 :RMSOTS>2 .3.CO;2.

Moore, S.C., 1976, Geology and thrust fault tectonics of parts of the Argus and Slate ranges, Inyo County, California.

Nasdala, L., Reiners, P.W., Garver, J.I., Kennedy, A.K., Stern, R.A., Balan, E., andWirth, R., 2004, Incomplete retention of radiation damage in zircon from Sri Lanka: American Mineralogist, v. 89, p. 219-231.

Numelin, T., and Kirby, E., 2004, Evidence for Quaternary slip on a low angle normal fault: Searles Valley, California: EOS (Transactions, American Geophysical Union), v. 85 , no. 47.

Noble. L. F.. 1941, Structural features of the Virgin Springarea. Death Valley. California: Geological Society of America Bulletin, v. 52. p. 941-1000.

Oldow, J. S., Geissman, J. W., \& Stockli, D. F., 2008, Evolution and strain reorganization within late Neogene structural stepovers linking the central Walker Lane and northern Eastern California shear zone, westernGreat Basin: International Geology Review, v. 50, p. 270-290.

Paton, C., Hellstrom, J., Paul, B., Woodhead, J., \& Hergt, J., 2011, Iolite: Freeware for the visualisation and processing of mass spectrometric data. Journal of Analytical Atomic Spectrometry, 26(12), 2508. doi:10.1039/c1ja10172b.

Pullen, A., Ibáñez-Mejía, M., Gehrels, G. E., Ibáñez-Mejía, J. C., \& Pecha, M. (2014). What happens when $n=1000$ ? Creating large-n geochronological datasets with LAICP-MS for geologic investigations. J. Anal. At. Spectrom., 29(6), 971-980. doi:10.1039/c4ja00024b.

Reheis, M. C., \& Dixon, T. H., 1996, Kinematics of the Eastern California shear zone: Evidence for slip transfer from Owens and Saline Valley fault zones to Fish Lake Valley fault zone. Geology, 24(4), 339. doi:10.1130/0091-7613(1996)0242.3.co;2.

Renik, B., \& Christie-Blick, N. (2013). A new hypothesis for the amount and distribution of dextral displacement along the Fish Lake Valley-northern Death Valley-Furnace Creek fault zone, California-Nevada. Tectonics, 32(2), 123-145. doi:10.1029/2012tc003170. 
Reich, M., Ewing, R.C., Ehlers, T.A., and Becker, U., 2007, Low-temperature anisotropic diffusion of helium in zircon: Implications for zircon (U-Th)/He thermochronometry, Geochimica et Cosmochimica Acta, v. 71, p. 3119-3130.

Reiners, P. W., 2002, Temporal-compositional trends in intraplate basalt eruptions: Implications for mantle heterogeneity and melting processes. Geochemistry, Geophysics, Geosystems, 3(2), 1-30. doi:10.1029/2001gc000250.

Reiners, P.W., 2005, Zircon (U-Th)/He Thermochronometry, in Reiners, P.W. and Ehlers, T.A. eds., Thermochronology, Reviews in Mineralogy and Geochemistry, v. 58, p. 151-176.

Reiners, P. W., and M. T. Brandon, 2006, Using thermochronology to understand orogenic erosion, Annu. Rev. Earth Planet. Sci., 34(1), 419-466, doi:10.1146/annurev.earth.34.031405.125202.

Reiners, P.W., Brady, R., Farley, K.A., Fryxell, J.E., Wernicke, B.P., and Lux, D., 2000, Helium and Argon thermochronometry of the Gold Butte block, South Virgin Mountains, Nevada: Earth and Planetary Science Letters, v. 178, p. 315-326.

Reiners, P.W., and Farley, K.A., 2001, Influence of crystal size on apatite (U-Th)/He thermochronology: An example from the Bighorn Mountains, Wyoming: Earth and Planetary Science Letters, v. 188, p. 413-420.

Reiners, P.W., Farley, K.A., and Hickes, H.J., 2002, He diffusion and (U-Th)/He thermochronometry of zircon: Initial results from Fish Canyon Tuff and Gold Butte: Tectonophysics, v. 349, p. 247-308.

Reiners, P.W., Spell, T.L., Nicolescu, S., and Zanetti, K.A., 2004, Zircon (U-TH)/He thermochronometry: He diffusion and comparison with 40Ar/39Ar dating: Geochimica et Cosmochimica Acta, v. 68, p. 1857-1887.Shuster, D.L., Flowers, R.M., and Farley, K.A., 2006, The influence of natural radiation damage on helium diffusion kinetics in apatite: Earth and Planetary Science Letters, v. 249, doi: 10.1016/j.epsl.2006.07.028.

Saleeby, J., Pourhiet, L. L., Saleeby, Z., \& Gurnis, M., 2012, Epeirogenic transients related to mantle lithosphere removal in the southern Sierra Nevada region, California, part I: Implications of thermomechanical modeling. Geosphere, 8(6), 1286-1309. doi:10.1130/ges00746.1.

Serpa, L., and Pavlis, T.L., 1996, Three-dimensional model of the Cenozoic history of the Death Valley region, southeastern California: Tectonics, v. 15, no. 6, p. 1113-1128, doi: 10.1029/96TC01633.

Shervais, J.W., Murchey, B.L., Kimbrough, D.L., Renne, P.R., and Hanan, B., 2005, Radioisotopic and biostratigraphic age relations in the Coast Range ophiolite, northern California: Implications for the tectonic evolution of the Western Cordillera: Geological Society of America Bulletin, v. 117, p. 633-653, https://doi .org/10.1130/B25443.1. 
Shuster D. L., Flowers R. M., and Farley K. A., 2006, The influence of natural radiation damage on helium diffusion kinetics in apatite. Earth and Planetary Science Letters 249(3-4), 148-161.

Smith, G.I., Troxel, B.W., Gray, C.H., Jr., and Von, H.R., 1968, Geologic reconnaissance of the Slate Range, San Bernardino and Inyo counties, California: Special Report California Division of Mines and Geology, v. 96, p. 1-33.

Snow, J. K. 1992, Large-magnitude Permian shortening and continental-margin tectonics in the southern Cordillera. Geol. Soc. Amer. Bull., 104: 80-105.

Snow, J.K. and Lux, D.R., 1999, Tectono-sequence stratigraphy of Tertiary rocks in the Cottonwood Mountains and northern Death Valley area, California and Nevada: in Troxel, B.W., ed., Geological Society of America Special Paper, v. 333, p. 17-64.

Snow, J.K. and Wernicke, B.P., 1989, Uniqueness of geological correlations; an example from the Death Valley extended terrain: Geological Society of America Bulletin, v. 101, p. 1351-1362.

Snow, J.K., and Wernicke, B.P., 2000, Cenozoic tectonism in the central Basin and Range: Magnitude, rate and distribution of upper crustal strain: American Journal of Science, v. 300, p. 659-719.

Snyder, N.P. and Hodges, K.V., 2000, Depositional and tectonic evolution of a supradetachment basin: 40Ar/39Ar geochronology of the Nova Formation, Panamint Range, California: Basin Research, v. 12, p. 19-30.

Swanson, B. J. 1996. Structural geology and deformational history of the southern Inyo Mountains east of Keeler, Inyo County, California, Northridge: California State Univ.. Unpubl. M. S. thesis, 125 p.

Stockli, D., 2005, Application of low-temperature thermochronometry to extensional settings, in Reiners, P.W., and Ehlers, T.A., eds., Reviews in Mineralogy \& Geochemistry, Volume 58, Mineralogical Society of America, p. 411-448.

Stockli, D. F., Surpless, B. E., Dumitru, T. A., \& Farley, K. A., 2002, Thermochronological constraints on the timing and magnitude of Miocene and Pliocene extension in the central Wassuk Range, western Nevada. Tectonics, 21(4). doi:10.1029/2001tc001295.

Stockli, D.F., Farley, K.A., and Dumitru, T.A., 2000, Calibration of the apatite (U-Th)/ He thermochronometer on an exhumed fault block, White Mountains, California: Geology, v. 28, p. 983-986.

Stockli, D. F., Linn, J. K., Walker, J. D., \& Dumitru, T. A., 2001, Miocene unroofing of the Canyon Range during extension along the Sevier Desert Detachment, west central Utah. Tectonics, 20(3), 289-307. doi:10.1029/2000tc001237

Stockli, D.F., Surpless, B.E., and Dumitru, T.A., 2002, Thermochronological constraints on the timing and magnitude of Miocene and Pliocene extension in the central Wassuk Range, western Nevada: Tectonics, v. 21, p. 10-1 -10-19. 
Streitz, R., and Stinson, M.C., 1974, Geologic map of California, Death Valley sheet: California Division of Mines and Geology, scale 1:250,000.

Tian, Y., N. Qiu, B. P. Kohn, C. Zhu, S. Hu, A. J. W. Gleadow, and B. I. McInnes, 2012, Detrital zircon (U-Th)/He thermochronometry of the Mesozoic Daba Shan Foreland Basin, central China: Evidence for timing of post-orogenic denudation, Tectonophysics,570-571, 65-77,doi:10.1016/j.tecto.2012.08.010.

Vermeesch, P., 2004, How many grains are needed for a provenance study? Earth Planet.Sci. Lett. 224 (3-4), 441-451.

Vermeesch, P., 2012. On the visualisation of detrital age distributions. Chem. Geol. 312313, 190-194.https://doi.org/10.1016/j.chemgeo.2012.04.021.

Walker, J.D., Andrew, J.E., and Kirby, E., 2005, Strain transfer and partitioning between the Panamint Valley, Searles Valley, and Ash Hill fault zones, California: Geosphere, v. 1, p. 111-118, doi: 10.1130/GES00014.1.

Walker, J.D., Bidgoli, T.S., Diderickson, B.D., Stockli, D.F., and Andrew, J.F., 2014, Middle Miocene to recent exhumation of the Slate Range, eastern California, and implications for the timing of extension and the transition to transtension: Geosphere, doi:10.1130/GES00947.1.

Walker, J. D., Martin, M. W., Bartley, J. M. and Coleman, D. S. 1990. Timing and kinematics of deformation in the Cronese Hills, California, and implications for Mesozoic structure of the southwestern Cordillera. Geology, 18: 554-557.

Workman, J. B., Menges, C. M., Page, W. R., Taylor, E. M., Ekren, E. B., Rowley, P. D., ... Wright, L. A. (2002). Geologic map of the Death Valley ground-water model area, Nevada and California [Map].

Wells M.L., Snee L.W., Blythe A.E., 2000, Dating of major normal fault systems using thermochronology: An example from the Raft River detachment, Basin and Range, western United States. J Geophys Res 105: 16,303-16,327.

Wells, M.L. and Hoisch, T.D., 2008, The role of mantle delamination in widespread Late Cretaceous extension and magmatism in the Cordilleran orogen, western United States: Geological Society of America Bulletin, v. 120, p. 515-530.

Wernicke, B.P., 1992, Cenozoic extensional tectonics of the U.S. Cordillera, in Burchfield, B.C., Lipman, P.W., and Zoback, M.L., eds., Geology of North America, Volume G3, The Cordilleran Orogen: Conterminous U.S: Geological Society of America, p. $553-581$.

Wernicke, B.P., Axen, G.J., and Snow, J.K., 1988, Basin and Range extensional tectonics at the latitude of Las Vegas, Nevada: Geological Society of America Bulletin, v. 100, p. $1738-1757$.

Wernicke, B., Walker, J.D., and Hodges, K.V., 1986, Geologic evolution of Tucki Mountain and vicinity, central Panamint Range, in Dunne, G.C., ed., Mesozoic- 
Cenozoic structural evolution of selected areas, east-central California: Geological Society of America Cordilleran Section, Field Trip 2 Guidebook, p. 67-80.

Wernicke, B., \& Snow, J. K.,1998, Cenozoic Tectonism in the Central Basin and Range: Motion of the Sierran-Great Valley Block. International Geology Review, 40(5), 403-410. doi:10.1080/00206819809465217.

Wrucke, C. T., Stevens, C. H., \& Wooden, J. L. (1995). The Butte Valley and Layton Well Thrusts of eastern California: Distribution and regional significance. Tectonics, 14(5), 1165-1171. doi:10.1029/95tc01932.

Wessel, P., W. H. F. Smith, R. Scharroo, J. Luis, and F. Wobbe, Generic Mapping Tools: Improved Version Released, EOS Trans. AGU, 94(45), p. 409-410, 2013. doi:10.1002/2013EO450001.

Wolf, R.A., Farley, K.A., and Kass, D.M., 1998, Modeling of the temperature sensitivity of the apatite (U-Th)/He thermochronometer: Chemical Geology, v. 148, p. 105-114.

Wolf, R.A., Farley, K.A., and Silver, L.T., 1996, Helium diffusion and low temperature thermochronometry of apatite: Geochimica et Cosmochimica Acta, v. 60, p. 42314240, doi: 10 .1016 /S0016 -7037 (96)00192-5.

Wolfe, M.R., and Stockli, D.F., 2010, Zircon (U-Th)/He thermochronometry in the KTB drillhole, Germany, and its implications for bulk He diffusion kinetics in zircon: Earth And Planetary Science Letters, v. 295, p. 69-82.

Wood, J., and Saleeby, J., 1997, Late Cretaceous-Paleocene extensional collapse and disaggregation of the southernmost Sierra Nevada batholith: International Geology Review, v. 39, p. 973-1009.

Wright, R. H., Campbell, R. H., \& Nilsen, T. H., 1974, Preparation and Use of Isopleth Maps of Landslide Deposits. Geology, 2(10), 483. doi:10.1130/00917613(1974)22.0.co;2.

Wright, L.A., Otton, J., and Troxel, B.W., 1974, Turtleback surfaces of Death Valley viewed as phenomena of extension: Geology, v. 2, p. 53-54, doi: 10.1130/ 00917613(1974)2<53:TSODVV>2.0.CO;2.

Wrucke, C. T., Stevens, C. H., \& Wooden, J. L. (1995). The Butte Valley and Layton Well Thrusts of eastern California: Distribution and regional significance. Tectonics, 14(5), 1165-1171. doi:10.1029/95tc01932.

Wyld, S.J., and Wright, J.E., 2001, New evidence for Cre-taceous strike-slip faulting in the United States Cor-dillera and implications for terrane-displacement, deformation patterns, and plutonism: American Journal of Science, v. 301, p. 150181, https://doi.org/10.2475/ajs.301.2.150. 


\section{APPENDICES}




\begin{tabular}{|c|c|c|c|c|c|c|c|c|c|c|c|c|c|}
\hline Sample & $\begin{array}{l}\text { Latitude } \\
\text { (N) }\end{array}$ & $\begin{array}{l}\text { Longitude } \\
\text { (W) }\end{array}$ & $\begin{array}{l}\text { Age } \\
\text { (Ma) }\end{array}$ & $\begin{array}{l}\text { Error } \\
\text { (Ma) }\end{array}$ & $\begin{array}{c}\mathrm{U} \\
(\mathrm{ppm})\end{array}$ & $\begin{array}{c}\text { Th } \\
\text { (ppm) }\end{array}$ & $\begin{array}{c}\text { Sm } \\
(\mathrm{ppm})\end{array}$ & [U]e & $\mathrm{ThU} \mathrm{U}$ & $\begin{array}{c}\mathrm{He} \\
(\mathrm{nmol} / \mathrm{g})\end{array}$ & $\begin{array}{l}\text { Mass } \\
(\mathrm{mg})\end{array}$ & $\mathrm{Ft}^{*}$ & ESR \\
\hline \multicolumn{14}{|c|}{ Skidoo Pluton zircon data } \\
\hline$z 19 S P O 1-2$ & $36^{\circ} 25^{\prime} 42.11^{\prime \prime}$ & $117^{\circ} 8^{\prime 3.44^{\prime \prime}}$ & 42.7 & 3.41 & 384.9 & 120.9 & 2.3 & 412.8 & 0.31 & 780 & 12.05 & 0.82 & 65.01 \\
\hline zl9SP01-3 & $36^{\circ} 25^{\prime} 42.11^{\prime \prime}$ & $117^{\circ} 83.44^{\prime \prime}$ & 18.1 & 1.45 & 209.8 & 169.7 & 117.7 & 249.5 & 0.81 & 18.8 & 5.98 & 0.77 & 51.79 \\
\hline z19SP02-1 & $36^{\circ} 25^{\prime} 52.42^{\prime \prime}$ & $117^{\circ} 831.98$ & 19.7 & 1.58 & 165.4 & 96.7 & 3.8 & 187.7 & 0.58 & 15.8 & 7.41 & 0.79 & 56.25 \\
\hline zl9SP02-2 & $36^{\circ} 25^{\prime} 52.42^{\prime \prime}$ & $117^{\circ} 831.99$ & 18.5 & 1.48 & 178.9 & 50.1 & 0.0 & 190.4 & 0.28 & 15.4 & 12.21 & 0.81 & 61.80 \\
\hline z19SP02-3 & $36^{\circ} 25^{\prime} 52.42^{\prime \prime}$ & $117^{\circ} 831.100$ & 187 & 1.49 & 771.8 & 82.9 & 0.0 & 790.9 & 0.11 & 62.7 & 7.22 & 0.79 & 54.08 \\
\hline z19SP03-1 & $36^{\circ} 267.41^{\prime \prime}$ & $117^{\circ} 911.74^{\prime \prime}$ & 8.9 & 0.71 & 874.6 & 51.9 & 0.0 & 886.6 & 0.06 & 33.1 & 7.07 & 0.78 & 52.24 \\
\hline z19SP03-2 & $36^{\circ} 267.41^{\prime \prime}$ & $117^{\circ} 9_{11.74^{\prime \prime}}$ & 14.8 & 1.19 & 572.7 & 62.0 & 2.0 & 587.0 & 0.11 & 38.7 & 14.19 & 0.82 & 66.43 \\
\hline z19SP03-3 & $36^{\circ} 267.41^{\prime \prime}$ & $117^{\circ} 911.74^{\prime \prime}$ & 12.1 & 0.97 & 75.9 & 38.5 & 1.4 & 84.8 & 0.51 & 4.8 & 39.92 & 0.87 & 94.87 \\
\hline z19SP04-1 & $36^{\circ} 25^{\prime} 42.22^{\prime \prime}$ & $117^{\circ} 11^{\prime} 4.51^{\prime \prime}$ & 5.4 & 0.43 & 896.5 & 163.3 & 2.7 & 934.1 & 0.18 & 21.9 & 10.26 & 0.81 & 60.13 \\
\hline z19SP04-2 & $36^{\circ} 25^{\prime} 42.22^{\prime \prime}$ & $117^{\circ} 11^{\prime} 4.51^{\prime \prime}$ & 4.7 & 0.37 & 647.4 & 106.9 & 0.0 & 672.0 & 0.17 & 12.9 & 5.14 & 0.76 & 47.94 \\
\hline z19SP04-4 & $36^{\circ} 25^{\prime} 42.22^{\prime \prime}$ & $117^{\circ} 11^{\prime} 4.51^{\prime \prime}$ & 4.5 & 0.36 & 287.2 & 70.0 & 0.0 & 303.4 & 0.24 & 5.6 & 4.87 & 0.75 & 46.77 \\
\hline z19SP05-1 & $36^{\circ} 2635.00^{\prime \prime}$ & $117^{\circ} 951.00^{\prime \prime}$ & 6.8 & 0.54 & 1856.6 & 108.0 & 0.0 & 1881.5 & 0.06 & 54.6 & 7.27 & 0.79 & 55.31 \\
\hline z19SP05-2 & $36^{\circ} 2635.00^{\prime \prime}$ & $117^{\circ} 951.00^{\prime \prime}$ & 6.4 & 0.51 & 119.8 & 138.3 & 7.2 & 151.7 & 1.15 & 3.8 & 3.89 & 0.72 & 41.71 \\
\hline z19SP05-3 & $36^{\circ} 2635.00^{\prime \prime}$ & $117^{\circ} 951.00^{\prime \prime}$ & 14.4 & 1.15 & 417.9 & 54.3 & 2.3 & 430.4 & 0.13 & 27.5 & 12.24 & 0.82 & 65.60 \\
\hline \multicolumn{14}{|c|}{ Goler Canyon zircon data } \\
\hline $\mathrm{z} 12 \mathrm{GC} 01-1$ & $35^{\circ} 52^{\prime} 0.82^{\prime \prime}$ & $117^{\circ} 5 ' 53.46^{\prime \prime}$ & 89.6 & 7.17 & 90.5 & 92.0 & 5.1 & 111.7 & 1.02 & 46.6 & 34.37 & 0.85 & 84.37 \\
\hline $\mathrm{z} 12 \mathrm{GC} 01-2$ & $35^{\circ} 52^{\prime} 0.82^{\prime \prime}$ & $117^{\circ} 5^{\prime} 53.46^{\prime \prime}$ & 72.6 & 5.81 & 130.6 & 81.2 & 5.6 & 149.3 & 0.62 & 47.4 & 10.38 & 0.80 & 61.13 \\
\hline $\mathrm{z} 12 \mathrm{GC} 01-3$ & $35^{\circ} 52^{\prime} 0.82^{\prime \prime}$ & $11^{\circ} 5^{\prime} 53.46^{\prime \prime}$ & 70.4 & 5.63 & 100.1 & 62.8 & 0.0 & 114.5 & 0.63 & 35.6 & 12.03 & 0.81 & 64.54 \\
\hline $\mathrm{z} 12 \mathrm{GC} 02-1$ & $35^{\circ} 51^{\prime} 48.91^{\prime \prime}$ & $117^{\circ} 66.55^{\prime \prime}$ & 84.6 & 6.77 & 180.9 & 82.3 & 0.0 & 199.8 & 0.45 & 71.8 & 7.94 & 0.78 & 54.05 \\
\hline $\mathrm{z} 12 \mathrm{GC} 02-2$ & $35^{\circ} 51^{\prime} 48.91^{\prime \prime}$ & $117^{\circ} 66.55^{\prime \prime}$ & 99.8 & 7.99 & 60.0 & 45.8 & -7.9 & 70.5 & 0.76 & 27.7 & 3.67 & 0.72 & 42.23 \\
\hline $\mathrm{z} 12 \mathrm{GC} 02-3$ & $35^{\circ} 51^{\prime} 48.91^{\prime \prime}$ & $117^{\circ} 66.55^{\prime \prime}$ & 67.9 & 5.43 & 110.1 & 91.4 & 0.0 & 131.1 & 0.83 & 38.2 & 7.68 & 0.79 & 56.72 \\
\hline $\mathrm{z} 12 \mathrm{GC} 03-1$ & $35^{\circ} 51^{\prime} 48.89^{\prime \prime}$ & $117^{\circ} 621.49^{\prime \prime}$ & 66.1 & 5.29 & 181.3 & 128.2 & 0.0 & 210.8 & 0.71 & 55.2 & 4.50 & 0.73 & 43.32 \\
\hline $\mathrm{z} 12 \mathrm{GC} 03-2$ & $35^{\circ} 51^{\prime} 48.89^{\prime \prime}$ & $117^{\circ} 621.49^{\prime \prime}$ & 82.4 & 6.59 & 100.7 & 75.0 & 0.0 & 118.0 & 0.74 & 40.9 & 7.16 & 0.77 & 52.44 \\
\hline
\end{tabular}




\begin{tabular}{|c|c|c|c|c|c|c|c|c|c|c|c|c|c|}
\hline Sample & $\begin{array}{l}\text { Latitude } \\
\text { (N) }\end{array}$ & $\begin{array}{l}\text { Longitude } \\
\text { (W) }\end{array}$ & $\begin{array}{l}\text { Age } \\
\text { (Ma) }\end{array}$ & $\begin{array}{l}\text { Error } \\
\text { (Ma) }\end{array}$ & $\begin{array}{c}\mathrm{U} \\
(\mathrm{ppm})\end{array}$ & $\begin{array}{c}\text { Th } \\
\text { (ppm) }\end{array}$ & $\begin{array}{c}\mathrm{Sm} \\
(\mathrm{ppm})\end{array}$ & {$[\mathrm{U}]_{\mathbf{e}}$} & $\mathrm{Th} / \mathrm{U}$ & $\begin{array}{c}\mathrm{He} \\
(\mathrm{nmol} / \mathrm{g})\end{array}$ & $\begin{array}{l}\text { Mass } \\
\text { (mg) }\end{array}$ & $\mathrm{Ft}^{*}$ & ESR \\
\hline $\mathrm{z} 12 \mathrm{GC} 03-3$ & $35^{\circ} 51^{\prime} 48.89^{\prime \prime}$ & $117^{\circ} 621.49^{\prime \prime}$ & 61.9 & 4.95 & 100.5 & 64.3 & 0.0 & 115.3 & 0.64 & 30.9 & 9.69 & 0.80 & 59.00 \\
\hline z12GC04-1 & $35^{\circ} 52^{\circ} 0.01^{\prime \prime}$ & $117^{\circ} 6^{\prime} 36.44^{\prime \prime}$ & 432.2 & 34.57 & 23.1 & 18.1 & -2.1 & 27.2 & 0.78 & 53.0 & 13.65 & 0.81 & 62.59 \\
\hline $\mathrm{z} 12 \mathrm{GC} 04-2$ & $35^{\circ} 52^{\prime} 0.01^{\prime \prime}$ & $117^{\circ} 636.44^{\prime \prime}$ & 61.5 & 4.92 & 170.6 & 105.1 & 26 & 194.8 & 0.62 & 51.8 & 11.08 & 0.80 & 58.84 \\
\hline $\mathrm{z} 12 \mathrm{GC} 04-3$ & $35^{\circ} 52^{\circ} 0.01^{\prime \prime}$ & $117^{\circ} 636.44^{\prime \prime}$ & 65.0 & 5.20 & 121.6 & 65.9 & 0.0 & 136.8 & 0.54 & 38.9 & 10.32 & 0.81 & 61.27 \\
\hline $\mathrm{z} 12 \mathrm{GC} 05-2$ & $35^{\circ} 5137.73^{\prime \prime}$ & $117^{\circ} 655.40^{\prime \prime}$ & 82.6 & 6.61 & 88.6 & 67.6 & -5.8 & 104.1 & 0.76 & 35.0 & 4.98 & 0.75 & 47.09 \\
\hline $\mathrm{z} 12 \mathrm{GC} 05-3$ & $35^{\circ} 51^{\prime 37.73^{\prime \prime}}$ & $117^{\circ} 655.40^{\prime \prime}$ & 77.6 & 6.21 & 64.1 & 49.6 & 0.0 & 75.5 & 0.77 & 25.6 & 9.89 & 0.80 & 60.99 \\
\hline $\mathrm{z} 12 \mathrm{GC} 05-4$ & $35^{\circ} 51^{\prime} 37.73^{\prime \prime}$ & $117^{\circ} 655.40^{\prime \prime}$ & 77.7 & 6.21 & 186.2 & 127.4 & -6.9 & 215.5 & 0.68 & 65.5 & 4.21 & 0.72 & 41.67 \\
\hline z12GC07-1 & $35^{\circ} 51^{\prime 32.34^{\prime \prime}}$ & $117^{\circ} 727.55^{\prime \prime}$ & 78.8 & 6.31 & 165.2 & 57.8 & 0.0 & 178.5 & 0.35 & 56.9 & 4.71 & 0.74 & 45.35 \\
\hline $\mathrm{z} 12 \mathrm{GC} 07-3$ & $35^{\circ} 51^{\prime} 32.34^{\prime \prime}$ & $117^{\circ} 727.55^{\prime \prime}$ & 80.2 & 6.41 & 359.7 & 124.4 & -20.9 & 388.2 & 0.35 & 125.1 & 4.16 & 0.74 & 44.53 \\
\hline z12GC08-1 & $35^{\circ} 51^{\prime 3} 3.56^{\prime \prime}$ & $117^{\circ} 746.54^{\prime \prime}$ & 76.0 & 6.08 & 106.0 & 106.2 & 0.0 & 130.4 & 1.00 & 38.1 & 2.95 & 0.71 & 39.94 \\
\hline z12GC08-2 & $35^{\circ} 51^{\prime} 33.56^{\prime \prime}$ & $117^{\circ} 746.54^{\prime \prime}$ & 60.9 & 4.88 & 83.8 & 45.1 & 0.0 & 94.2 & 0.54 & 22.9 & 4.03 & 0.74 & 44.14 \\
\hline z12GC09-1 & $35^{\circ} 51^{\prime} 33.13^{\prime \prime}$ & $117^{\circ} 83.50^{\prime \prime}$ & 82.7 & 6.62 & 87.9 & 78.5 & 60.7 & 106.3 & 0.89 & 37.0 & 6.68 & 0.77 & 52.49 \\
\hline z12GC09-2 & $35^{\circ} 51^{3} 33.13^{\prime \prime}$ & $117^{\circ} 83.50^{\prime \prime}$ & 76.1 & 6.09 & 54.7 & 33.0 & 0.0 & 62.3 & 0.60 & 19.4 & 5.83 & 0.76 & 48.08 \\
\hline z12GC09-3 & $35^{\circ} 51^{\prime} 33.13^{\prime \prime}$ & $117^{\circ} 83.50^{\prime \prime}$ & 86.5 & 6.92 & 75.8 & 30.1 & 0.0 & 82.8 & 0.40 & 28.1 & 4.14 & 0.72 & 41.58 \\
\hline $\mathrm{z} 12 \mathrm{GC} 10-1$ & $35^{\circ} 51^{137.23 "}$ & $117^{\circ} 821.23^{\prime \prime}$ & 68.1 & 5.45 & 196.2 & 220.9 & 0.0 & 247.1 & 1.13 & 64.4 & 2.54 & 0.70 & 39.67 \\
\hline $\mathrm{z} 12 \mathrm{GCl} 10-2$ & $35^{\circ} 5137.23^{\prime \prime}$ & $117^{\circ} 821.23^{\prime \prime}$ & 58.8 & 4.71 & 67.7 & 43.0 & 0.0 & 77.6 & 0.64 & 17.2 & 2.48 & 0.69 & 37.60 \\
\hline $\mathrm{z} 12 \mathrm{GC} 10-3$ & $35^{\circ} 51^{\prime 37.23 "}$ & $117^{\circ} 821.23^{\prime \prime}$ & 63.9 & 5.11 & 105.5 & 55.0 & 0.0 & 118.2 & 0.52 & 28.9 & 2.66 & 0.71 & 39.14 \\
\hline $212 \mathrm{GC} 13-3$ & $35^{\circ} 51^{\prime 29} .15^{\prime \prime}$ & $117^{\circ} S^{\prime} 59.40^{\prime \prime}$ & 5.4 & 0.44 & 41.4 & 33.3 & 112.3 & 49.6 & 0.50 & 1.1 & 5.42 & 0.76 & 49.70 \\
\hline $\mathrm{z} 12 \mathrm{GC} 15-2$ & $35^{\circ} 51^{\prime 27.13^{\prime \prime}}$ & $117^{\circ} 914.22^{\prime \prime}$ & 56.9 & 4.55 & 40.7 & 41.8 & 0.0 & 50.4 & 1.03 & 11.1 & 2.86 & 0.71 & 40.62 \\
\hline $\mathrm{z} 12 \mathrm{GC} 15-3$ & $35^{\circ} 51^{\prime 27.13^{\prime \prime}}$ & $117^{\circ} 9_{14.22^{\prime \prime}}$ & 34.2 & 273 & 36.3 & 26.6 & 0.0 & 42.4 & 0.73 & 5.5 & 2.43 & 0.70 & 38.82 \\
\hline $\mathrm{z} 12 \mathrm{GC} 15-4$ & $35^{\circ} 51^{\prime 27.13^{\prime \prime}}$ & $117^{\circ} 9_{14.22^{\prime \prime}}$ & 68.5 & 5.48 & 27.2 & 21.8 & 0.0 & 32.3 & 0.80 & 9.3 & 5.82 & 0.78 & 53.23 \\
\hline \multicolumn{14}{|c|}{ Panamint Range Sites zircon data } \\
\hline z19PR01-1 & $35^{\circ} 55^{\prime} 18.00^{\prime \prime}$ & $117^{\circ} 10^{\prime} 58.00^{\prime \prime}$ & 24.3 & 1.95 & 64.6 & 27.5 & 1.9 & 71.0 & 0.42 & 7.7 & 15.15 & 0.83 & 68.79 \\
\hline
\end{tabular}




\begin{tabular}{|c|c|c|c|c|c|c|c|c|c|c|c|c|c|}
\hline Sample & $\begin{array}{l}\text { Latitude } \\
\text { (N) }\end{array}$ & $\begin{array}{l}\text { Longitude } \\
\text { (W) }\end{array}$ & $\begin{array}{l}\text { Age } \\
\text { (Ma) }\end{array}$ & $\begin{array}{l}\text { Error } \\
\text { (Ma) }\end{array}$ & $\underset{(\mathrm{ppm})}{\mathrm{U}}$ & $\begin{array}{c}\mathrm{Th} \\
(\mathrm{ppm})\end{array}$ & $\begin{array}{c}\text { Sm } \\
(\mathrm{ppm})\end{array}$ & [U]le & $\mathrm{Th} \mathbf{U}$ & $\begin{array}{c}\mathrm{He} \\
(\mathrm{nmol} / \mathrm{g})\end{array}$ & $\begin{array}{l}\text { Mass } \\
\text { (mg) }\end{array}$ & $\mathrm{Ft}^{*}$ & ESR \\
\hline z19PR01-2 & $35^{\circ} 55^{\prime} 18.00^{\prime \prime}$ & $117^{\circ} 10^{\prime} 58.00^{\prime \prime}$ & 36.8 & 295 & 109.0 & 50.7 & 0.0 & 120.7 & 0.47 & 19.6 & 12.40 & 0.81 & 64.28 \\
\hline Z19PR01-3 & $35^{\circ} 55^{\prime} 18.00^{\prime \prime}$ & $117^{\circ} 10^{\prime} 58.00^{\prime \prime}$ & 26.7 & 2.14 & 165.6 & 102.7 & 28 & 189.3 & 0.62 & 21.6 & 10.12 & 0.79 & 56.18 \\
\hline Z19PR02-1 & $35^{\circ} 55^{\prime} 18.00^{\prime \prime}$ & $117^{\circ} 11^{\prime} 6.00^{\prime \prime}$ & 21.1 & 1.69 & 99.7 & 48.4 & 6.3 & 110.9 & 0.49 & 10.4 & 13.44 & 0.82 & 65.84 \\
\hline Z19PR02-2 & $35^{\circ} 55^{\prime} 18.00^{\prime \prime}$ & $117^{\circ} 11^{\prime} 6.00^{\prime \prime}$ & 23.0 & 1.84 & 75.3 & 40.2 & 0.0 & 84.5 & 0.53 & 9.0 & 25.48 & 0.85 & 81.47 \\
\hline Z19PR02-3 & $35^{\circ} 55^{\prime} 18.00^{\prime \prime}$ & $117^{\circ} 111^{\prime} 6.00^{\prime \prime}$ & 26.5 & 2.12 & 194.7 & 64.1 & 0.0 & 209.5 & 0.33 & 23.5 & 8.18 & 0.78 & 54.00 \\
\hline z19PR03-1 & $36^{\circ} 13^{\prime} 1.00^{\prime \prime}$ & $117^{\circ} 13^{\prime} 13.00^{\prime \prime}$ & 7.2 & 0.57 & 838.8 & 574.0 & 3.4 & 971.0 & 0.68 & 29.1 & 8.32 & 0.77 & 51.96 \\
\hline Z19PR03-2 & $36^{\circ} 13^{\prime} 1.00^{\prime \prime}$ & $11^{\circ} 13^{\prime} 13.00^{\prime \prime}$ & 5.8 & 0.46 & 259.6 & 278.7 & 3.2 & 323.7 & 1.07 & 8.4 & 17.75 & 0.83 & 72.50 \\
\hline Z19PR 03-3 & $36^{\circ} 13^{\prime} 1.00^{\prime \prime}$ & $117^{\circ} 13^{\prime} 13.00^{\prime \prime}$ & 8.1 & 0.65 & 257.5 & 225.6 & 0.0 & 309.4 & 0.88 & 10.6 & 8.62 & 0.78 & 54.94 \\
\hline z19PR04-1 & $36^{\circ} 12^{\prime} 54.00^{\prime \prime}$ & $117^{\circ} 13^{\prime} 41.00^{\prime \prime}$ & 24.9 & 1.99 & 92.2 & 39.1 & 1.6 & 101.2 & 0.42 & 11.3 & 17.50 & 0.83 & 70.83 \\
\hline Z19PR04-2 & $36^{\circ} 12^{\prime} 54.00^{\prime \prime}$ & $11^{\circ} 13^{\prime} 41.00^{\prime \prime}$ & 12.1 & 0.97 & 1767.0 & 1580.1 & 14356.2 & 2202.5 & 0.89 & 108.7 & 3.89 & 0.73 & 44.52 \\
\hline z19PR05-1 & $36^{\circ} 12^{\prime} 39.00^{\prime \prime}$ & $117^{\circ} 13^{\circ} 9.00^{\prime \prime}$ & 7.6 & 0.61 & 1.0 & 1.0 & 56.2 & 1.5 & 0.99 & 0.1 & 55.02 & 0.88 & 106.27 \\
\hline z19PR05-2 & $36^{\circ} 12^{2} 39.00^{\circ \prime}$ & $117^{\circ} 13^{\circ} 9.00^{\prime \prime}$ & 126 & 1.01 & 73.3 & 51.1 & 0.0 & 85.0 & 0.70 & 4.2 & 3.88 & 0.73 & 43.97 \\
\hline \multicolumn{14}{|c|}{ Hunter Mountain zircon data } \\
\hline 212HM01-1 & $36^{\circ} 32^{\prime} 46.32^{\prime \prime}$ & $117^{\circ} 30^{\prime} 44.45^{\prime \prime}$ & 91.6 & 7.32 & 102.9 & 79.7 & 0.0 & 121.3 & 0.77 & 49.0 & 12.65 & 0.81 & 64.10 \\
\hline 212HM01-2 & $36^{\circ} 32^{\prime} 46.32^{\prime \prime}$ & $117^{\circ} 30^{\prime} 44.45^{\prime \prime}$ & 107.8 & 8.62 & 120.9 & 79.2 & 0.0 & 139.2 & 0.65 & 67.3 & 14.35 & 0.82 & 68.49 \\
\hline z12HM01-3 & $36^{\circ} 32^{\prime} 46.32^{\prime \prime}$ & $11^{\circ} 30^{\prime} 44.45^{\prime \prime}$ & 67.9 & 5.43 & 79.1 & 73.8 & 0.0 & 96.0 & 0.93 & 26.6 & 4.53 & 0.75 & 47.52 \\
\hline zl2HM02-1 & $36^{\circ} 32^{\prime 2} 29.71^{\prime \prime}$ & $117^{\circ} 31^{9} 9.35^{\prime \prime}$ & 75.7 & 6.06 & 72.7 & 34.7 & 0.0 & 80.7 & 0.48 & 29.5 & 54.15 & 0.89 & 108.12 \\
\hline z12HM02-3 & $36^{\circ} 3229.71^{\prime \prime}$ & $117^{\circ} 31^{\prime} 9.35^{\prime \prime}$ & 97.9 & 7.83 & 65.6 & 40.9 & 0.8 & 75.1 & 0.62 & 35.0 & 37.41 & 0.87 & 97.59 \\
\hline $\mathrm{z} 12 \mathrm{HM} 02-4$ & $36^{\circ} 3229.71^{\prime \prime}$ & $117^{\circ} 31^{\prime} 9.35^{\prime \prime}$ & 124.2 & 9.94 & 13.8 & 65.0 & 26.2 & 28.9 & 4.71 & 17.2 & 36.59 & 0.87 & 95.45 \\
\hline 212HM03-1 & $36^{\circ} 32^{\prime} 17.17^{\prime \prime}$ & $117^{\circ} 32 / 22.87^{\prime \prime}$ & 43.8 & 3.51 & 82.5 & 52.7 & 28.8 & 94.8 & 0.64 & 18.8 & 17.11 & 0.83 & 72.06 \\
\hline $\mathrm{z} 12 \mathrm{HM} 03-2$ & $36^{\circ} 32^{\prime} 17.17^{\prime \prime}$ & $117^{\circ} 32 \cdot 22.87^{\prime \prime}$ & 89.9 & 7.19 & 58.0 & 38.4 & 1.4 & 66.8 & 0.66 & 28.5 & 42.24 & 0.87 & 96.69 \\
\hline zl2HM03-3 & $36^{\circ} 32^{\prime} 17.17^{\prime \prime}$ & $117^{\circ} 32 ' 22.87^{\prime \prime}$ & 76.3 & 6.11 & 99.4 & 53.7 & 1.4 & 111.8 & 0.54 & 38.9 & 20.72 & 0.84 & 75.34 \\
\hline z12HM04-2 & $36^{\circ} 32^{\prime} 8.13^{\prime \prime}$ & $117^{\circ} 32^{\prime} 4.18^{\prime \prime}$ & 82.5 & 6.60 & 338.2 & 156.7 & 26 & 374.2 & 0.46 & 133.8 & 11.02 & 0.80 & 58.65 \\
\hline
\end{tabular}




\begin{tabular}{|c|c|c|c|c|c|c|c|c|c|c|c|c|c|}
\hline Sample & $\begin{array}{c}\text { Latitude } \\
\text { (N) }\end{array}$ & $\begin{array}{l}\text { Longitude } \\
\text { (W) }\end{array}$ & $\begin{array}{l}\text { Age } \\
\text { (Ma) }\end{array}$ & $\begin{array}{l}\text { Error } \\
\text { (Ma) } \\
\end{array}$ & $\begin{array}{c}\mathrm{U} \\
\text { (ppm) }\end{array}$ & $\begin{array}{c}\text { Th } \\
\text { (ppm) }\end{array}$ & $\begin{array}{c}\mathrm{Sm} \\
(\mathrm{ppm})\end{array}$ & [U]e & $\mathrm{Th} / \mathrm{U}$ & $\begin{array}{c}\mathrm{He} \\
(\mathrm{nmol} / \mathrm{g})\end{array}$ & $\begin{array}{l}\text { Mass } \\
\text { (mg) }\end{array}$ & $\mathrm{Ft}^{*}$ & ESR \\
\hline z12HM05-1 & $36^{\circ} 31^{\prime} 48.06^{\prime \prime}$ & $117^{\circ} 32 ' 21.40^{\prime \prime}$ & 68.7 & 5.49 & 70.3 & 33.3 & 1.0 & 77.9 & 0.47 & 25.1 & 28.62 & 0.86 & 88.98 \\
\hline Z12HM05-2 & $36^{\circ} 31^{\prime} 48.06^{\prime \prime}$ & $117^{\circ} 322^{\prime 2} 1.40^{\prime \prime}$ & 80.9 & 6.47 & 38.0 & 24.6 & 1.1 & 43.7 & 0.65 & 16.5 & 26.15 & 0.86 & 86.29 \\
\hline 212HM06-3 & $36^{\circ} 31^{\prime} 38.48^{\prime \prime}$ & $117^{\circ} 32^{\prime} 44.06^{\prime \prime}$ & 100.8 & 8.06 & 71.1 & 69.6 & 1.3 & 87.2 & 0.98 & 41.6 & 44.38 & 0.87 & 94.19 \\
\hline Z12HMOG-4 & $36^{\circ} 31^{\prime} 3848^{\prime \prime}$ & $117^{\circ} 32^{\prime} 44.06^{\prime \prime}$ & 207.4 & 16.60 & 35.5 & 25.2 & 0.8 & 41.3 & 0.71 & 39.6 & 34.05 & 0.84 & 77.64 \\
\hline 212HM07-1 & $36^{\circ} 31^{\prime} 59.94^{\prime \prime}$ & $117^{\circ} 33^{\prime} 40.24^{\prime \prime}$ & 99.0 & 7.92 & 101.8 & 68.4 & 0.0 & 117.6 & 0.67 & 52.4 & 18.95 & 0.83 & 70.03 \\
\hline z12HM07-2 & $36^{\circ} 31^{\prime 59.94^{\prime \prime}}$ & $117^{\circ} 33^{\prime} 40.24^{\prime \prime}$ & 95.5 & 7.64 & 156.2 & 84.0 & 0.0 & 175.5 & 0.54 & 72.8 & 10.64 & 0.80 & 58.90 \\
\hline z12HM07-3 & $36^{\circ} 31^{\prime} 59.94^{\prime \prime}$ & $11^{\circ} 33^{\prime} 40.24^{\prime \prime}$ & 86.8 & 6.94 & 74.3 & 38.4 & 0.0 & 83.2 & 0.52 & 31.3 & 10.32 & 0.80 & 58.76 \\
\hline 212HM08-1 & $36^{\circ} 31^{\prime} 46.12^{\prime \prime}$ & $117^{\circ} 33^{\prime} 19.45^{\prime \prime}$ & 95.0 & 7.60 & 125.6 & 113.5 & 29 & 151.7 & 0.90 & 66.9 & 28.71 & 0.85 & 82.69 \\
\hline zl2HM08-2 & $36^{\circ} 31^{\prime} 46.12^{\prime \prime}$ & $117^{\circ} 33^{\prime} 19.45^{\prime \prime}$ & 83.7 & 6.70 & 90.5 & 60.8 & 26 & 104.6 & 0.67 & 38.8 & 10.87 & 0.81 & 64.93 \\
\hline
\end{tabular}

"Samples in italics were not included our calculated mean ages. 


\begin{tabular}{|c|c|c|c|c|c|c|c|c|c|c|c|c|c|}
\hline Sample & $\begin{array}{c}\text { Latitude } \\
\text { (N) }\end{array}$ & $\begin{array}{l}\text { Longitude } \\
\text { (W) }\end{array}$ & $\begin{array}{l}\text { Age } \\
\text { (Ma) }\end{array}$ & $\begin{array}{l}\text { Error } \\
\text { (Ma) } \\
\end{array}$ & $\begin{array}{c}\mathrm{U} \\
\text { (ppm) }\end{array}$ & $\begin{array}{c}\begin{array}{c}\text { Th } \\
\text { (ppm) }\end{array} \\
\end{array}$ & $\begin{array}{c}\text { Sm } \\
\text { (ppm) }\end{array}$ & {$[\mathrm{U}]_{\mathrm{e}}$} & $\mathrm{Th} / \mathrm{U}$ & $\begin{array}{c}\mathrm{He} \\
(\mathrm{nmol} / \mathrm{g})\end{array}$ & $\begin{array}{l}\text { Mass } \\
\text { (mg) }\end{array}$ & $\mathbf{F t}^{*}$ & ESR \\
\hline \multicolumn{14}{|c|}{$\underline{\text { Skidoo Pluton apatite data }}$} \\
\hline 19SP01-1 & $36^{\circ} 25^{\prime} 42.11^{\prime \prime}$ & $117^{\circ} 83.44^{\prime \prime}$ & 4.8 & 0.29 & 11.6 & 87.1 & 202.7 & 32.7 & 7.51 & 0.6 & 4.31 & 0.72 & 56.77 \\
\hline $19 \mathrm{SP} 01-2$ & $36^{\circ} 25^{\prime} 42.11^{\prime \prime}$ & $117^{\circ} 83.44^{\prime \prime}$ & 10.5 & 0.63 & 2.1 & 3.7 & 100.4 & 3.4 & 1.78 & 0.1 & 3.08 & 0.69 & 50.32 \\
\hline $19 \mathrm{SP} 01-3$ & $36^{\circ} 25^{\prime} 42.11^{\prime \prime}$ & $117^{\circ} 83.44^{\prime \prime}$ & 8.3 & 0.50 & 6.5 & 9.8 & 158.8 & 9.6 & 1.50 & 0.4 & 11.21 & 0.79 & 76.53 \\
\hline $19 \mathrm{SP} 01-4$ & $36^{\circ} 25^{\prime} 42.11^{\prime \prime}$ & $117^{\circ} 8^{\prime} 3.44^{\prime \prime}$ & 6.4 & 0.38 & 5.1 & 8.3 & 129.7 & 7.6 & 1.64 & 0.2 & 4.34 & 0.71 & 54.12 \\
\hline 19SP02-1 & $36^{\circ} 25^{\prime} 52.42^{\prime \prime}$ & $117^{\circ} 831.98$ & 6.0 & 0.36 & 5.2 & 7.7 & 187.5 & 7.9 & 1.46 & 0.2 & 1.35 & 0.59 & 36.38 \\
\hline 19SP02-2 & $36^{\circ} 25^{\prime} 52.42^{\prime \prime}$ & $117^{\circ} 8^{\prime} 31.99$ & 9.8 & 0.59 & 12.9 & 59.2 & 187.6 & 27.5 & 4.59 & 1.0 & 2.25 & 0.64 & 43.34 \\
\hline $19 \mathrm{SP} 02-3$ & $36^{\circ} 25^{\prime} 52.42^{\prime \prime}$ & $117^{\circ} 831.100$ & 5.7 & 0.34 & 19.1 & 9.8 & 191.3 & 22.3 & 0.51 & 0.5 & 2.50 & 0.68 & 45.75 \\
\hline $19 \mathrm{SP} 02-4$ & $36^{\circ} 25^{\prime} 52.42^{\prime \prime}$ & $117^{\circ} 8^{\prime} 31.101$ & 5.1 & 0.31 & 7.1 & 30.1 & 156.6 & 14.8 & 4.26 & 0.3 & 6.30 & 0.75 & 63.66 \\
\hline 19SP03-1 & $36^{\circ} 267.41^{\prime \prime}$ & $117^{\circ} 9^{\prime \prime 11.74^{\prime \prime}}$ & 4.4 & 0.26 & 8.6 & 6.9 & 161.5 & 11.0 & 0.81 & 0.2 & 7.51 & 0.75 & 61.07 \\
\hline $19 \mathrm{SP} 03-2$ & $36^{\circ} 267.41^{\prime \prime}$ & $117^{\circ} 9^{\prime} 11.74^{\prime \prime}$ & 6.0 & 0.36 & 7.4 & 6.5 & 132.4 & 9.6 & 0.87 & 0.2 & 8.95 & 0.77 & 67.10 \\
\hline 19SP03-3 & $36^{\circ} 267.41^{\prime \prime}$ & $117^{\circ} 9^{\prime} 11.74^{\prime \prime}$ & 5.0 & 0.30 & 13.6 & 63.5 & 174.7 & 29.0 & 4.68 & 0.6 & 10.84 & 0.78 & 74.42 \\
\hline $19 \mathrm{SP} 03-4$ & $36^{\circ} 267.41^{\prime \prime}$ & $117^{\circ} 9^{\prime} 11.74^{\prime \prime}$ & 7.4 & 0.44 & 9.2 & 7.3 & 178.4 & 11.7 & 0.79 & 0.4 & 4.42 & 0.72 & 54.08 \\
\hline $195 P 04-1$ & $36^{\circ} 25^{\prime} 42.22^{\prime \prime}$ & $117^{\circ} 11^{\prime} 4.51^{\prime \prime}$ & 189 & 1.13 & 7.0 & 5.1 & 156.1 & 89 & 0.73 & o.s & 9.04 & 0.78 & 70.31 \\
\hline 19SP04-2 & $36^{\circ} 25^{\prime} 42.22^{\prime \prime}$ & $117^{\circ} 11^{\prime} 4.51^{\prime \prime}$ & 3.3 & 0.20 & 9.3 & 8.6 & 106.8 & 11.8 & 0.92 & 0.1 & 3.16 & 0.68 & 46.92 \\
\hline 19SP04-3 & $36^{\circ} 25^{\prime} 42.22^{\prime \prime}$ & $117^{\circ} 11^{\prime} 4.51^{\prime \prime}$ & 4.0 & 0.24 & 11.0 & 199.9 & 227.9 & 58.1 & 18.23 & 0.9 & 5.57 & 0.72 & 58.50 \\
\hline $19 \mathrm{SP} 04-4$ & $36^{\circ} 25^{\prime} 42.22^{\prime \prime}$ & $117^{\circ} 11^{\prime} 4.51^{\prime \prime}$ & 3.8 & 0.23 & 7.5 & 29.3 & 112.9 & 14.8 & 3.93 & 0.3 & 12.75 & 0.79 & 78.73 \\
\hline 19SP05-1 & $36^{\circ} 26^{\prime} 35.00^{\prime \prime}$ & $117^{\circ} 9^{\prime} 51.00^{\prime \prime}$ & 1.5 & 0.09 & 8.4 & 3.2 & 111.6 & 9.7 & 0.39 & 0.1 & 2.52 & 0.69 & 47.74 \\
\hline \multicolumn{14}{|c|}{ Goler Canyon apatite data } \\
\hline $12 \mathrm{GC} 01-1$ & $35^{\circ} 52^{\prime} 0.82^{\prime \prime}$ & $117^{\circ} 5^{\prime} 53.46^{\prime \prime}$ & 7.2 & 0.43 & 5.7 & 27.4 & 102.5 & 12.6 & 4.78 & 0.3 & 2.26 & 0.65 & 44.63 \\
\hline $12 \mathrm{GCO}-2$ & $35^{\circ} 52^{\prime} 0.82^{\prime \prime}$ & $117^{\circ} 5^{\prime} 53.46^{\prime \prime}$ & 10.3 & 0.62 & 9.7 & 36.6 & 126.7 & 18.7 & 3.78 & 0.8 & 6.18 & 0.74 & 62.29 \\
\hline $12 \mathrm{GCO}-3$ & $35^{\circ} 52^{\prime} 0.82^{\prime \prime}$ & $117^{\circ} 5^{\prime} 53.46^{\prime \prime}$ & 9.9 & 0.59 & 14.1 & 65.7 & 169.0 & 30.1 & 4.65 & 1.1 & 3.60 & 0.67 & 48.04 \\
\hline $12 \mathrm{GCO}-4$ & $35^{\circ} 52^{\prime} 0.82^{\prime \prime}$ & $117^{\circ} 5^{\prime} 53.46^{\prime \prime}$ & 11.3 & 0.68 & 1.2 & 10.8 & 169.8 & 4.6 & 8.78 & 0.2 & 2.73 & 0.67 & 48.12 \\
\hline $12 \mathrm{GC} 02-1$ & $35^{\circ} 51^{\prime} 48.91^{\prime \prime}$ & $117^{\circ} 66.55^{\prime \prime}$ & 9.0 & 0.54 & 9.2 & 36.7 & 160.7 & 18.5 & 3.98 & 0.7 & 4.69 & 0.72 & 55.72 \\
\hline $12 \mathrm{GC} 02-2$ & $35^{\circ} 51^{\prime} 48.91^{\prime \prime}$ & $117^{\circ} 66.55^{\prime \prime}$ & 9.5 & 0.57 & 13.6 & 54.5 & 137.9 & 26.9 & 4.00 & 1.0 & 2.73 & 0.68 & 48.30 \\
\hline
\end{tabular}




\begin{tabular}{|c|c|c|c|c|c|c|c|c|c|c|c|c|c|}
\hline Sample & $\begin{array}{l}\text { Latitude } \\
\text { (N) }\end{array}$ & $\begin{array}{c}\text { Longitude } \\
\text { (W) }\end{array}$ & $\begin{array}{l}\text { Age } \\
\text { (Ma) }\end{array}$ & $\begin{array}{l}\text { Error } \\
\text { (Ma) }\end{array}$ & $\begin{array}{c}\mathrm{U} \\
\text { (ppm) }\end{array}$ & $\begin{array}{c}\mathrm{Th} \\
(\mathrm{ppm})\end{array}$ & $\begin{array}{c}\text { Sm } \\
\text { (ppm) }\end{array}$ & [U]e & $\mathrm{Th} / \mathrm{U}$ & $\begin{array}{c}\mathrm{He} \\
(\mathrm{nmnol} / \mathrm{g})\end{array}$ & $\begin{array}{l}\text { Mass } \\
(\mathrm{mg})\end{array}$ & $\mathrm{Ft}^{*}$ & ESR \\
\hline $12 \mathrm{GC} 02-4$ & $35^{\circ} 51^{\prime} 48.91^{\prime \prime}$ & $117^{\circ} 66.55^{\prime \prime}$ & 8.4 & 0.50 & 6.5 & 27.9 & 116.7 & 13.5 & 4.27 & 0.4 & 3.97 & 0.70 & 52.55 \\
\hline $12 \mathrm{GC} 03-1$ & $35^{\circ} 51^{\prime} 48.89^{\prime \prime}$ & $117^{\circ} 6^{\prime 21} .49^{\prime \prime}$ & 8.0 & 0.48 & 4.0 & 24.7 & 289.4 & 11.1 & 6.15 & 0.4 & 3.71 & 0.69 & 51.54 \\
\hline $12 \mathrm{GC} 03-2$ & $35^{\circ} 51^{\prime} 48.89^{\prime \prime}$ & $117^{\circ} 6^{\prime} 21.49^{\prime \prime}$ & 11.8 & 0.71 & 7.2 & 32.8 & 171.0 & 15.6 & 4.58 & 0.7 & 3.05 & 0.67 & 48.06 \\
\hline $12 \mathrm{GC} 03-4$ & $35^{\circ} 51^{\prime} 48.89^{\prime \prime}$ & $117^{\circ} 621.49^{\prime \prime}$ & 10.7 & 0.64 & 6.8 & 43.7 & 151.9 & 17.7 & 6.39 & 0.8 & 4.39 & 0.71 & 55.40 \\
\hline $12 \mathrm{GC} 04-1$ & $35^{\circ} 52^{\prime} 0.01^{\prime \prime}$ & $117^{\circ} 6^{\prime} 36.44^{\prime \prime}$ & 12.3 & 0.74 & 8.0 & 32.8 & 114.9 & 16.1 & 4.10 & 0.7 & 2.52 & 0.64 & 42.27 \\
\hline $12 \mathrm{GC} 04-2$ & $35^{\circ} 52^{\prime} 0.01^{\prime \prime}$ & $117^{\circ} 6^{\prime} 36.44^{\prime \prime}$ & 12.4 & 0.75 & 9.6 & 34.4 & 88.6 & 17.9 & 3.60 & 0.8 & 1.96 & 0.63 & 41.97 \\
\hline $12 \mathrm{GC} 04-3$ & $35^{\circ} 52^{\prime} 0.01^{\prime \prime}$ & $117^{\circ} 6^{\prime} 36.44^{\prime \prime}$ & 9.8 & 0.59 & 10.9 & 42.3 & 150.9 & 21.4 & 3.87 & 0.8 & 2.88 & 0.66 & 45.42 \\
\hline $12 \mathrm{GC} 04-4$ & $35^{\circ} 52^{\prime} 0.01^{\prime \prime}$ & $117^{\circ} 6^{\prime} 36.44^{\prime \prime}$ & 9.7 & 0.58 & 7.0 & 35.5 & 195.9 & 16.2 & 5.04 & 0.5 & 1.33 & 0.58 & 36.39 \\
\hline $12 \mathrm{GC} 05-1$ & $35^{\circ} 51^{\prime} 37.73^{\prime \prime}$ & $117^{\circ} 6^{\prime} 55.40^{\prime \prime}$ & 24.2 & 1.45 & 4.3 & 17.6 & 109.2 & 9.0 & 4.06 & 0.9 & 3.98 & 0.70 & 53.01 \\
\hline $12 \mathrm{GC} 05-2$ & $35^{\circ} 51^{\prime} 37.73^{\prime \prime}$ & $117^{\circ} 655.40^{\prime \prime}$ & 26.4 & 1.59 & 6.2 & 18.4 & 154.0 & 11.2 & 2.96 & 1.2 & 4.33 & 0.70 & 51.74 \\
\hline $12 \mathrm{GC} 05-3$ & $35^{\circ} 51^{\prime} 37.73^{\prime \prime}$ & $117^{\circ} 6^{\prime} 55.40^{\prime \prime}$ & 6.8 & 0.41 & 11.4 & 65.4 & 311.1 & 28.0 & 5.73 & 0.7 & 2.61 & 0.64 & 43.05 \\
\hline $12 \mathrm{GC} 05-4$ & $35^{\circ} 51 ' 37.73^{\prime \prime}$ & $117^{\circ} 6^{6} 55.40^{\prime \prime}$ & 15.9 & 0.95 & 5.6 & 24.8 & 163.4 & 12.1 & 4.46 & 0.8 & 3.37 & 0.69 & 51.46 \\
\hline $12 \mathrm{GC} 06-1$ & $35^{\circ} 51^{\prime} 35.66^{\prime \prime}$ & $117^{\circ} 7^{\prime} 11.10^{\prime \prime}$ & 18.3 & 1.10 & 25.8 & 42.1 & 166.7 & 36.3 & 1.63 & 2.3 & 1.91 & 0.64 & 41.90 \\
\hline $12 \mathrm{GCO}-3$ & $35^{\circ} 51^{\prime} 35.66^{\prime \prime}$ & $117^{\circ} 7^{\prime} 11.10^{\prime \prime}$ & 9.6 & 0.58 & 25.6 & 53.4 & 143.9 & 38.6 & 2.09 & 1.3 & 1.81 & 0.64 & 41.56 \\
\hline $12 \mathrm{GC} 07 \cdot 1$ & $35^{\circ} 51^{\prime} 32.34^{\prime \prime}$ & $117^{\circ} 7^{\prime} 27.55^{\prime \prime}$ & 33.7 & 2.02 & 30.4 & 12.3 & 125.1 & 33.9 & 0.41 & 4.0 & 1.62 & 0.64 & 40.17 \\
\hline $12 \mathrm{GC} 07-3$ & $35^{\circ} 51^{\prime} 32.34^{\prime \prime}$ & $117^{\circ} 7^{\prime} 27.55^{\prime \prime}$ & 35.0 & 2.10 & 44.6 & 20.7 & 165.4 & 50.2 & 0.46 & 5.7 & 1.05 & 0.59 & 34.45 \\
\hline $12 \mathrm{GC} 07-4$ & $35^{\circ} 51^{\prime} 32.34^{\prime \prime}$ & $117^{\circ} 7^{\prime} 27.55^{\prime \prime}$ & 39.3 & 2.36 & 46.5 & 25.7 & 221.6 & 53.5 & 0.55 & 8.0 & 3.27 & 0.69 & 48.06 \\
\hline $12 \mathrm{GC} 08-2$ & $35^{\circ} 51^{\prime} 33.56^{\prime \prime}$ & $117^{\circ} 7^{\prime} 46.54^{\prime \prime}$ & 25.0 & 1.50 & 6.3 & 17.2 & 235.7 & 11.4 & 2.74 & 1.0 & 1.72 & 0.63 & 41.27 \\
\hline $12 \mathrm{GC} 08-3$ & $35^{\circ} 51^{\prime} 33.56^{\prime \prime}$ & $117^{\circ} 7^{\prime} 46.54^{\prime \prime}$ & 31.0 & 1.86 & 18.3 & 22.8 & 221.3 & 24.7 & 1.25 & 2.9 & 2.75 & 0.68 & 48.17 \\
\hline $12 \mathrm{GCO}-4$ & $35^{\circ} 51^{\prime} 33.56^{\prime \prime}$ & $117^{\circ} 7^{\prime} 46.54^{\prime \prime}$ & 40.7 & 2.44 & 8.5 & 31.6 & 271.8 & 17.2 & 3.71 & 2.7 & 2.56 & 0.67 & 46.57 \\
\hline $12 \mathrm{GC} 09-1$ & $35^{\circ} 51 ' 33.13^{\prime \prime}$ & $117^{\circ} 83.50^{\prime \prime}$ & 22.0 & 1.32 & 5.6 & 15.1 & 186.5 & 10.0 & 2.70 & 0.8 & 2.33 & 0.67 & 46.41 \\
\hline $12 \mathrm{GC} 09-2$ & $35^{\circ} 51^{\prime} 33.13^{\prime \prime}$ & $117^{\circ} 83.50^{\prime \prime}$ & 19.6 & 1.17 & 6.0 & 20.1 & 300.5 & 12.1 & 3.34 & 0.8 & 1.06 & 0.57 & 34.90 \\
\hline $12 \mathrm{GC} 09-3$ & $35^{\circ} 51^{\prime} 33.13^{\prime \prime}$ & $117^{\circ} 83.50^{\prime \prime}$ & 25.9 & 1.55 & 5.7 & 22.2 & 197.9 & 11.8 & 3.92 & 1.0 & 1.17 & 0.58 & 35.60 \\
\hline $12 \mathrm{GC} 09-4$ & $35^{\circ} 51^{\prime 33.13 "}$ & $11^{\circ} 83.50^{\prime \prime}$ & 11.2 & 0.67 & 5.5 & 17.2 & 203.9 & 10.5 & 3.12 & 0.4 & 1.42 & 0.60 & 37.47 \\
\hline
\end{tabular}




\begin{tabular}{|c|c|c|c|c|c|c|c|c|c|c|c|c|c|}
\hline Sample & $\begin{array}{l}\text { Latitude } \\
\text { (N) }\end{array}$ & $\begin{array}{l}\text { Longitude } \\
\text { (W) }\end{array}$ & $\begin{array}{l}\text { Age } \\
\text { (Ma) }\end{array}$ & $\begin{array}{l}\text { Error } \\
\text { (Ma) }\end{array}$ & $\begin{array}{c}\mathrm{U} \\
(\mathrm{ppm})\end{array}$ & $\begin{array}{c}\mathrm{Th} \\
(\mathrm{ppm})\end{array}$ & $\begin{array}{c}\mathrm{Sm} \\
\text { (ppm) }\end{array}$ & {$[\mathrm{U}]_{\mathbf{e}}$} & ThU & $\begin{array}{c}\mathrm{He} \\
(\mathrm{nmol} / \mathrm{g})\end{array}$ & $\begin{array}{l}\text { Mass } \\
(\mathrm{mg})\end{array}$ & $\mathrm{Ft}^{*}$ & ESR \\
\hline $12 \mathrm{GC} 10-1$ & $35^{\circ} 51^{\prime} 37.23^{\prime \prime}$ & $117^{\circ} 8^{\prime} 21.23^{\prime \prime}$ & 65.9 & 3.95 & 20.6 & 57.3 & 30.8 & 34.0 & 2.78 & 6.8 & 0.94 & 0.56 & 33.33 \\
\hline $12 \mathrm{GCl} 0-3$ & $35^{\circ} 51^{\prime} 37.23^{\prime \prime}$ & $117^{\circ} 8^{\prime 21} .23^{\prime \prime}$ & 13.8 & 0.83 & 9.6 & 21.1 & 242.9 & 15.7 & 2.19 & 0.9 & 4.90 & 0.73 & 59.05 \\
\hline $12 \mathrm{GCl} 0-4$ & $35^{\circ} 51^{\prime} 37.23^{\prime \prime}$ & $117^{\circ} 8^{\prime 2} 21.23^{\prime \prime}$ & 16.1 & 0.97 & 5.0 & 9.6 & 142.9 & 7.9 & 1.93 & 0.5 & 3.65 & 0.71 & 53.26 \\
\hline $12 \mathrm{GCl} 3-1$ & $35^{\circ} 5129.15^{\prime \prime}$ & $117^{\circ} 8^{\prime} 59.40^{\prime \prime}$ & 4.2 & 0.25 & 95.7 & 80.3 & 235.3 & 115.4 & 0.84 & 1.8 & 2.71 & 0.68 & 47.47 \\
\hline $12 \mathrm{GCl} 3-2$ & $35^{\circ} 51^{\prime 29.15^{\prime \prime}}$ & $117^{\circ} 8^{\prime} 59.40^{\prime \prime}$ & 4.3 & 0.26 & 77.2 & 90.8 & 217.1 & 99.2 & 1.18 & 1.6 & 2.67 & 0.68 & 47.46 \\
\hline $12 \mathrm{GCl} 3-3$ & $35^{\circ} 51^{\prime 29.15^{\prime \prime}}$ & $117^{\circ} 8^{\prime} 59.40^{\prime \prime}$ & 4.0 & 0.24 & 105.0 & 85.9 & 291.0 & 126.2 & 0.82 & 1.9 & 3.29 & 0.69 & 48.37 \\
\hline $12 \mathrm{GCl} 3-4$ & $35^{\circ} 51^{\prime 29} 21^{\prime \prime}$ & $117^{\circ} 8^{\prime} 59.40^{\prime \prime}$ & 3.7 & 0.22 & 86.9 & 55.0 & 124.8 & 100.1 & 0.63 & 1.3 & 2.32 & 0.67 & 44.88 \\
\hline $12 \mathrm{GCl} 5-1$ & $35^{\circ} 51^{\prime 27.13 "}$ & $117^{\circ} 9^{\prime} 14.22^{\prime \prime}$ & 4.3 & 0.26 & 6.6 & 13.1 & 32.6 & 9.7 & 2.00 & 0.2 & 3.55 & 0.71 & 53.23 \\
\hline $12 \mathrm{GCl} 5-2$ & $35^{\circ} 5127.13^{\prime \prime}$ & $117^{\circ} 9^{\prime} 14.22^{\prime \prime}$ & 3.7 & 0.22 & 24.9 & 53.3 & 105.5 & 37.7 & 2.14 & 0.5 & 3.02 & 0.69 & 50.35 \\
\hline $12 \mathrm{GCl} 5-3$ & $35^{\circ} 5127.13^{\prime \prime}$ & $117^{\circ} 9^{\prime} 14.22^{\prime \prime}$ & 3.2 & 0.19 & 10.8 & 27.8 & 62.2 & 17.5 & 2.58 & 0.2 & 1.86 & 0.63 & 41.42 \\
\hline $12 \mathrm{GCl} 5-4$ & $35^{\circ} 5127.13^{\prime \prime}$ & $117^{\circ} 9^{\prime} 14.22^{\prime \prime}$ & 4.2 & 0.25 & 9.0 & 31.0 & 88.3 & 16.6 & 3.44 & 0.2 & 1.31 & 0.60 & 38.31 \\
\hline \multicolumn{14}{|c|}{ Panamint Range Sites apatite data } \\
\hline 19PR01-1 & $35^{\circ} 55^{\prime} 18.00^{\prime \prime}$ & $117^{\circ} 1058.00^{\prime \prime}$ & 28 & 0.17 & 26.0 & 40.6 & 41.3 & 35.5 & 1.56 & 0.4 & 5.05 & 0.72 & 55.37 \\
\hline 19PR01-2 & $35^{\circ} 55^{\prime} 18.00^{\prime \prime}$ & $117^{\circ} 1058.00^{\prime \prime}$ & 2.7 & 0.16 & 46.3 & 99.3 & 53.4 & 69.5 & 2.14 & 0.8 & 6.15 & 0.74 & 61.31 \\
\hline 19PR01-3 & $35^{\circ} 55^{\prime} 18.00^{\prime \prime}$ & $117^{\circ} 10^{\prime} 58.00^{\prime \prime}$ & 3.0 & 0.18 & 33.1 & 69.3 & 29.9 & 49.2 & 2.09 & 0.6 & 4.98 & 0.73 & 58.91 \\
\hline 19PR01-4 & $35^{\circ} 55^{\prime} 18.00^{\prime \prime}$ & $117^{\circ} 1058.00^{\prime \prime}$ & 2.9 & 0.17 & 29.6 & 81.7 & 65.5 & 48.7 & 2.76 & 0.6 & 16.44 & 0.82 & 88.68 \\
\hline 19PR 02-1 & $35^{\circ} 55^{\prime} 18.00^{\prime \prime}$ & $117^{\circ} 11^{\prime} 6.00^{\prime \prime}$ & 2.6 & 0.15 & 32.5 & 39.2 & 109.7 & 42.1 & 1.21 & 0.5 & 7.08 & 0.76 & 65.71 \\
\hline 19PR02-3 & $35^{\circ} 55^{\prime} 18.00^{\prime \prime}$ & $117^{\circ} 11^{\prime} 6.00^{\prime \prime}$ & 3.0 & 0.18 & 67.9 & 82.0 & 71.0 & 87.1 & 1.21 & 0.9 & 1.68 & 0.63 & 39.83 \\
\hline 19PR 02-4 & $35^{\circ} 55^{\prime} 18.00^{\prime \prime}$ & $117^{\circ} 11^{\prime} 6.00^{\prime \prime}$ & 2.3 & 0.14 & 57.6 & 85.5 & 110.5 & 77.9 & 1.48 & 0.7 & 2.70 & 0.69 & 49.28 \\
\hline 19PR04-1 & $36^{\circ} 12^{\prime} 54.00^{\prime \prime}$ & $117^{\circ} 13^{\prime} 41.00^{\prime \prime}$ & 6.0 & 0.36 & 10.0 & 12.7 & 877.2 & 17.3 & 1.28 & 0.5 & 4.61 & 0.72 & 55.75 \\
\hline 19PR04-2 & $36^{\circ} 12^{\prime \prime} 54.00^{\prime \prime}$ & $117^{\circ} 13^{\prime} 41.00^{\prime \prime}$ & 1.4 & 0.08 & 5.0 & 4.3 & 447.5 & 8.2 & 0.87 & 0.1 & 9.31 & 0.79 & 72.86 \\
\hline 19PR04-3 & $36^{\circ} 12^{\prime} 54.00^{\prime \prime}$ & $117^{\circ} 13^{\prime} 41.00^{\prime \prime}$ & 2.0 & 0.12 & 4.2 & 5.0 & 571.5 & 8.2 & 1.20 & 0.1 & 11.44 & 0.80 & 77.79 \\
\hline 19PR04-4 & $36^{\circ} 12^{\prime} 54.00^{\prime \prime}$ & $117^{\circ} 13^{\prime} 41.00^{\prime \prime}$ & 1.7 & 0.10 & 1.1 & 1.6 & 26.3 & 1.6 & 1.43 & 0.0 & 18.17 & 0.82 & 86.83 \\
\hline 19PR 05-1 & $36^{\circ} 12^{\prime} 39.00^{\prime \prime}$ & $117^{\circ} 13^{\prime} 9.00^{\prime \prime}$ & 3.2 & 0.19 & 7.3 & 8.0 & 318.2 & 10.7 & 1.09 & 0.2 & 6.60 & 0.76 & 64.65 \\
\hline 19PR05-2 & $36^{\circ} 12^{\prime} 39.00^{\prime \prime}$ & $117^{\circ} 13^{\prime} 9.00^{\prime \prime}$ & 6.9 & 0.41 & 25.8 & 13.2 & 469.0 & 31.1 & 0.51 & 1.0 & 17.33 & 0.82 & 87.01 \\
\hline 19PR05-3 & $36^{\circ} 12^{\prime} 39.00^{\prime \prime}$ & $117^{\circ} 13^{\circ} 9.00^{\prime \prime}$ & 19.6 & 1.17 & 12.0 & 10.7 & 709.6 & 181 & 0.89 & 1.7 & 13.85 & 0.81 & 50.74 \\
\hline
\end{tabular}




\begin{tabular}{|c|c|c|c|c|c|c|c|c|c|c|c|c|c|}
\hline Sample & $\begin{array}{l}\text { Latitude } \\
\text { (N) }\end{array}$ & $\begin{array}{l}\text { Longitude } \\
\text { (W) }\end{array}$ & $\begin{array}{l}\text { Age } \\
\text { (Ma) }\end{array}$ & $\begin{array}{l}\text { Error } \\
\text { (Ma) }\end{array}$ & $\begin{array}{c}\mathrm{U} \\
(\mathrm{ppm})\end{array}$ & $\begin{array}{c}\text { Th } \\
(\mathrm{ppm})\end{array}$ & $\begin{array}{c}\text { Sm } \\
(\mathrm{ppm})\end{array}$ & {$[\mathrm{U}]_{\mathbf{e}}$} & Th/U & $\begin{array}{c}\mathrm{He} \\
\text { (nnnol/g) }\end{array}$ & $\begin{array}{l}\text { Mass } \\
(\mathrm{mg})\end{array}$ & $\mathbf{F t}^{*}$ & ESR \\
\hline 19PR05-4 & $36^{\circ} 12 ' 39.00^{\prime \prime}$ & $117^{\circ} 13^{\prime} 9.00^{\prime \prime}$ & 7.3 & 0.44 & 63.5 & 12.2 & 303.9 & 67.9 & 0.19 & 1.7 & 1.67 & 0.64 & 39.84 \\
\hline \multicolumn{14}{|c|}{ Hunter Mountain apatite data } \\
\hline $12 \mathrm{HM} 01-1$ & $36^{\circ} 32^{\prime \prime} 46.32^{\prime \prime}$ & $117^{\circ} 30^{444.45^{\prime \prime}}$ & 66.4 & 3.99 & 38.7 & 90.3 & 87.8 & 59.9 & 2.33 & 16.2 & 5.61 & 0.74 & 61.03 \\
\hline $12 \mathrm{HM} 01-2$ & $36^{\circ} 32^{\prime} 46.32^{\prime \prime}$ & $117^{\circ} 3044.45^{\prime \prime}$ & 72.9 & 4.37 & 11.2 & 35.1 & 17.5 & 19.3 & 3.15 & 4.8 & 1.65 & 0.62 & 39.72 \\
\hline $12 \mathrm{HM} 01-3$ & $36^{\circ} 32^{\prime} 46.32^{\prime \prime}$ & $117^{\circ} 30^{444.45^{\prime \prime}}$ & 72.3 & 4.34 & 15.9 & 45.8 & 30.5 & 26.6 & 2.88 & 6.7 & 1.90 & 0.64 & 42.25 \\
\hline $12 \mathrm{HM} 01-4$ & $36^{\circ} 32^{\prime} 46.32^{\prime \prime}$ & $117^{\circ} 30^{444.45^{\prime \prime}}$ & 73.0 & 4.38 & 16.7 & 51.3 & 55.6 & 28.8 & 3.08 & 6.9 & 1.56 & 0.60 & 37.85 \\
\hline 12HM02-1 & $36^{\circ} 3229.71^{\prime \prime}$ & $117^{\circ} 31^{\prime} 9.35^{\prime \prime}$ & 68.9 & 4.13 & 8.6 & 33.0 & 36.5 & 16.4 & 3.83 & 4.4 & 3.96 & 0.70 & 52.74 \\
\hline $12 \mathrm{HM} 02-2$ & $36^{\circ} 32$ '29.71" & $117^{\circ} 31^{\prime} 9.35^{\prime \prime}$ & 67.0 & 4.02 & 8.2 & 35.6 & 18.2 & 16.5 & 4.36 & 3.7 & 1.59 & 0.60 & 38.52 \\
\hline 12HM02-3 & $36^{\circ} 32 ' 29.71^{\prime \prime}$ & $117^{\circ} 31^{\prime} 9.35^{\prime \prime}$ & 69.3 & 4.16 & 9.7 & 32.0 & 23.7 & 17.1 & 3.31 & 4.7 & 4.88 & 0.72 & 55.47 \\
\hline $12 \mathrm{HM} 02-4$ & $36^{\circ} 32 ' 29.71^{\prime \prime}$ & $117^{\circ} 31^{\prime} 9.35^{\prime \prime}$ & 72.4 & 4.34 & 9.4 & 36.4 & 26.2 & 17.9 & 3.88 & 5.0 & 4.42 & 0.71 & 53.94 \\
\hline 12HM03-1 & $36^{\circ} 32^{\prime} 17.17^{\prime \prime}$ & $117^{\circ} 32^{\prime 22.87^{\prime \prime}}$ & 62.4 & 3.74 & 9.4 & 34.5 & 59.0 & 17.6 & 3.67 & 3.9 & 1.96 & 0.64 & 42.20 \\
\hline $12 \mathrm{HM} 03-2$ & $36^{\circ} 32^{\prime} 17.17^{\prime \prime}$ & $117^{\circ} 32^{\prime 2} 22.87^{\prime \prime}$ & 60.1 & 3.60 & 9.0 & 29.3 & 26.3 & 15.9 & 3.24 & 3.4 & 2.20 & 0.65 & 44.65 \\
\hline $12 \mathrm{HM} 03-3$ & $36^{\circ} 32^{\prime} 17.17^{\prime \prime}$ & $117^{\circ} 32^{\prime 2} 22.87^{\prime \prime}$ & 58.7 & 3.52 & 11.1 & 35.5 & 73.7 & 19.6 & 3.19 & 4.5 & 3.93 & 0.71 & 54.44 \\
\hline $12 \mathrm{HM} 03-4$ & $36^{\circ} 32^{\prime} 17.17^{\prime \prime}$ & $117^{\circ} 32^{\prime 22} .87^{\prime \prime}$ & 63.9 & 3.83 & 7.6 & 29.5 & 51.1 & 14.6 & 3.89 & 3.6 & 3.40 & 0.69 & 51.13 \\
\hline $12 \mathrm{HM} 04-1$ & $36^{\circ} 32^{\prime} 8.13^{\prime \prime}$ & $117^{\circ} 32^{\prime} 4.18^{\prime \prime}$ & 65.4 & 3.93 & 12.1 & 29.0 & 105.0 & 19.3 & 2.40 & 4.5 & 1.93 & 0.64 & 42.22 \\
\hline $12 \mathrm{HM} 04-2$ & $36^{\circ} 32^{\prime} 8.13^{\prime \prime}$ & $117^{\circ} 32^{\prime 4} .18^{\prime \prime}$ & 82.6 & 4.96 & 17.7 & 61.6 & 141.7 & 32.5 & 3.48 & 8.8 & 1.43 & 0.59 & 36.80 \\
\hline $12 \mathrm{HM} 04-3$ & $36^{\circ} 32^{\prime} 8.13^{\prime \prime}$ & $117^{\circ} 32^{\prime} 4.18^{\prime \prime}$ & 68.5 & 4.11 & 14.0 & 60.0 & 149.7 & 28.5 & 4.30 & 6.1 & 1.16 & 0.56 & 34.05 \\
\hline $12 \mathrm{HM} 04-4$ & $36^{\circ} 32^{\prime} 8.13^{\prime \prime}$ & $117^{\circ} 32^{\prime} 4.18^{\prime \prime}$ & 86.5 & 5.19 & 11.9 & 51.0 & 117.3 & 24.3 & 4.28 & 7.1 & 1.48 & 0.61 & 39.34 \\
\hline 12HM05-1 & $36^{\circ} 31^{\prime} 48.06^{\prime \prime}$ & $117^{\circ} 32^{\prime 2} 21.40^{\prime \prime}$ & 69.6 & 4.17 & 15.5 & 49.6 & 72.3 & 27.3 & 3.19 & 6.0 & 1.20 & 0.57 & 35.04 \\
\hline 12HM05-2 & $36^{\circ} 31^{\prime} 48.06^{\prime \prime}$ & $117^{\circ} 32^{\prime 2} 21.40^{\prime \prime}$ & 75.1 & 4.51 & 13.0 & 45.6 & 38.3 & 23.7 & 3.50 & 5.9 & 1.51 & 0.60 & 37.96 \\
\hline $12 \mathrm{HM} 05-3$ & $36^{\circ} 31^{\prime} 48.06^{\prime \prime}$ & $117^{\circ} 32^{\prime 2} 21.40^{\prime \prime}$ & 61.3 & 3.68 & 27.0 & 74.3 & 80.8 & 44.5 & 2.75 & 9.4 & 1.79 & 0.62 & 40.43 \\
\hline $12 \mathrm{HM} 05-4$ & $36^{\circ} 31^{\prime} 48.06^{\prime \prime}$ & $117^{\circ} 32^{\prime} 21.40^{\prime \prime}$ & 69.6 & 4.18 & 44.4 & 101.9 & 136.4 & 68.6 & 2.29 & 16.6 & 1.91 & 0.63 & 41.16 \\
\hline 12HM06-1 & $36^{\circ} 31^{\prime} 38.48^{\prime \prime}$ & $117^{\circ} 32^{\prime} 44.06^{\prime \prime}$ & 65.1 & 3.91 & 14.6 & 46.8 & 20.1 & 25.5 & 3.20 & 6.2 & 2.96 & 0.67 & 47.76 \\
\hline 12HM06-2 & $36^{\circ} 31^{\prime} 38.48^{\prime \prime}$ & $117^{\circ} 32^{\prime} 44.06^{\prime \prime}$ & 77.0 & 4.62 & 12.9 & 48.2 & 93.9 & 24.4 & 3.74 & 7.3 & 4.45 & 0.70 & 52.74 \\
\hline $12 \mathrm{HM} 06-3$ & $36^{\circ} 31^{\prime} 38.48^{\prime \prime}$ & $117^{\circ} 32^{\prime} 44.06^{\prime \prime}$ & 62.3 & 3.74 & 17.5 & 51.7 & 43.2 & 29.6 & 2.96 & 6.5 & 2.07 & 0.64 & 42.50 \\
\hline $12 \mathrm{HM} 06-4$ & $36^{\circ} 31^{\prime} 38.48^{\prime \prime}$ & $117^{\circ} 32^{\prime} 44.06^{\prime \prime}$ & 70.2 & 4.21 & 32.8 & 73.5 & 33.1 & 49.9 & 2.24 & 12.2 & 2.70 & 0.64 & 41.65 \\
\hline
\end{tabular}




\begin{tabular}{|c|c|c|c|c|c|c|c|c|c|c|c|c|c|}
\hline $12 \mathrm{HM} 07-1$ & $36^{\circ} 31^{\prime} 59.94^{\prime \prime}$ & $117^{\circ} 33^{\prime} 40.24^{\prime \prime}$ & 72.0 & 4.32 & 8.4 & 46.5 & 19.6 & 19.2 & 5.52 & 4.3 & 1.52 & 0.57 & 34.88 \\
\hline $12 \mathrm{HM} 07-2$ & $36^{\circ} 31^{\prime} 59.94^{\prime \prime}$ & $117^{\circ} 33^{\prime} 40.24^{\prime \prime}$ & 93.2 & 5.59 & 11.7 & 44.5 & 42.2 & 22.1 & 3.81 & 8.0 & 4.24 & 0.70 & 52.62 \\
\hline $12 \mathrm{HM} 07-3$ & $36^{\circ} 31^{\prime} 59.94^{\prime \prime}$ & $117^{\circ} 33^{\prime} 40.24^{\prime \prime}$ & 73.9 & 4.44 & 9.1 & 43.0 & 35.6 & 19.2 & 4.72 & 5.5 & 4.19 & 0.71 & 53.91 \\
\hline $12 \mathrm{HMO} 7-4$ & $36^{\circ} 31^{\prime} 59.94^{\prime \prime}$ & $117^{\circ} 33^{\prime \prime} 40.24^{\prime \prime}$ & 371.7 & 22.30 & 83 & 50.3 & 37.7 & 200 & 6.09 & 24.5 & 1.58 & 0.59 & 37.32 \\
\hline $12 \mathrm{HM} 08-1$ & $36^{\circ} 31^{\prime} 46.12^{\prime \prime}$ & $117^{\circ} 33^{\prime} 19.45^{\prime \prime}$ & 74.2 & 4.45 & 26.5 & 122.6 & 31.3 & 54.9 & 4.62 & 15.9 & 4.76 & 0.71 & 54.99 \\
\hline 12HM08-2 & $36^{\circ} 31^{\prime} 46.12^{\prime \prime}$ & $117^{\circ} 33^{\prime} 19.45^{\prime \prime}$ & 67.3 & 4.04 & 20.0 & 76.3 & 35.0 & 37.7 & 3.82 & 11.6 & 23.02 & 0.83 & 95.77 \\
\hline HM08-3 & $36^{\circ} 31^{\prime} 46.12^{\prime \prime}$ & $117^{\circ} 33^{\prime} 19.45^{\prime \prime}$ & 72.7 & 4.36 & 15.8 & 82.1 & 43.9 & 35.0 & 5.19 & 11.2 & 18.39 & 0.80 & 81.33 \\
\hline
\end{tabular}

*Samples in italics were not included our calculated mean ages. 


\begin{tabular}{|c|c|c|c|c|c|c|c|c|c|c|c|c|c|c|c|c|c|}
\hline Sample Name: & & & & & & & & $207 / 235$ & & $206 / 238$ & & $207 / 206$ & & Bes & & Disc. & \\
\hline Grain $\#$ & [U] ppm & $\mathrm{U} / \mathrm{Th}$ & $207 / 235$ & $2 \sigma$ & $206 / 238$ & $2 \sigma$ & RHO & Age (Ma) & $2 \sigma$ & Age (Ma) & $2 \sigma$ & Age (Ma) & $2 \sigma$ & (Ma) & $2 \sigma$ & $\%$ & Rim or Core \\
\hline \multicolumn{18}{|c|}{ Upper Nova Formation Coarse Fraction } \\
\hline 19NB01_clasts_2.FIN2 & 134.4 & 0.82 & 4.719 & 0.071 & 0.3077 & 0.0038 & 0.501 & 1770 & 12 & 1729 & 19 & 1818 & 26 & 1818.0 & 26.0 & 4.9 & Single Age \\
\hline 19NB01_clasts_15.FIN2 & 191.7 & 1.30 & 13.45 & 0.1 & 0.5349 & 0.0039 & 0.563 & 2711.1 & 7.2 & 2761 & 16 & 2689 & 12 & 2689.0 & 12.0 & 2.7 & Single Age \\
\hline 19NB01_clasts_18.FIN2 & 155 & 1.28 & 2.968 & 0.049 & 0.2403 & 0.0037 & 0.600 & 1397 & 13 & 1387 & 19 & 1433 & 30 & 1433.0 & 30.0 & 3.2 & Single Age \\
\hline 19NB01_clasts_20.FIN2 & 148.3 & 1.14 & 4.117 & 0.068 & 0.2937 & 0.0049 & 0.447 & 1655 & 13 & 1662 & 25 & 1654 & 27 & 1654.0 & 27.0 & 0.5 & Single Age \\
\hline 19NB01_clasts_22.FIN2 & 107 & 0.54 & 2.226 & 0.045 & 0.2018 & 0.0026 & 0.505 & 1186 & 14 & 1185 & 14 & 1187 & 36 & 1187.0 & 36.0 & 0.2 & Single Age \\
\hline 19NB01_clasts_23.FIN2 & 137 & 1.63 & 2.752 & 0.066 & 0.2228 & 0.0048 & 0.579 & 1338 & 18 & 1295 & 26 & 1409 & 39 & 1409.0 & 39.0 & 8.1 & Single Age \\
\hline 19NB01_clasts_26.FIN2 & 998 & 11.02 & 0.1812 & 0.0077 & 0.02717 & 0.00089 & 0.597 & 168.9 & 6.6 & 172.8 & 5.6 & 113 & 74 & 1728 & 5.6 & 2.3 & Rim \\
\hline 19NB01_clasts_35.FIN2 & 92.3 & 1.19 & 3.09 & 0.054 & 0.2433 & 0.0032 & 0.440 & 1427 & 14 & 1403 & 17 & 1461 & 32 & 1461.0 & 32.0 & 4.0 & Single Age \\
\hline 19NB01_clasts_36.FIN2 & 139.9 & 1.53 & 4.07 & 0.13 & 0.2774 & 0.0065 & 0.810 & 1651 & 24 & 1576 & 33 & 1720 & 35 & 1720.0 & 35.0 & 8.4 & Core \\
\hline 19NB01_clasts_45.FIN2 & 90 & 1.21 & 3.34 & 0.068 & 0.2528 & 0.0049 & 0.485 & 1488 & 16 & 1451 & 25 & 1524 & 38 & 1524.0 & 38.0 & 4.8 & Single Age \\
\hline 19NB01_clasts_46.FIN2 & 55.6 & 1.24 & 3.058 & 0.065 & 0.2464 & 0.0035 & 0.378 & 1417 & 16 & 1419 & 18 & 1419 & 40 & 1419.0 & 40.0 & 0.0 & Single Age \\
\hline 19NB01_clasts_47.FIN2 & 800 & 2.13 & 0.1882 & 0.0052 & 0.02804 & 0.00046 & 0.308 & 174.9 & 4.4 & 178.3 & 29 & 138 & 62 & 178.3 & 2.9 & 1.9 & Single Age \\
\hline 19NB01_clasts_53.FIN2 & 112 & 1.27 & 3.64 & 0.07 & 0.2672 & 0.004 & 0.552 & 1554 & 16 & 1525 & 20 & 1593 & 32 & 1593.0 & 32.0 & 4.3 & Single Age \\
\hline 19NB01_clasts_61.FIN2 & 199.2 & 0.90 & 3.047 & 0.031 & 0.2453 & 0.002 & 0.309 & 1418.4 & 7.7 & 1414 & 10 & 1420 & 21 & 1420.0 & 21.0 & 0.4 & Single Age \\
\hline 19NB01_clasts_80.FIN2 & 67.4 & 0.46 & 4.593 & 0.095 & 0.3158 & 0.0042 & 0.523 & 1743 & 17 & 1768 & 21 & 1723 & 34 & 1723.0 & 34.0 & 2.6 & Single Age \\
\hline 19NB01_clasts_81.FIN2 & 1870 & 9.40 & 0.288 & 0.032 & 0.0373 & 0.0039 & 0.727 & 256 & 24 & 236 & 24 & 450 & 160 & 236.0 & 24.0 & 7.8 & Rim \\
\hline 19NB01_clasts_81.FIN2 & 221 & 0.80 & 2.021 & 0.056 & 0.1862 & 0.0046 & 0.665 & 1117 & 19 & 1099 & 25 & 1157 & 44 & 1157.0 & 44.0 & 5.0 & Core \\
\hline 19NB01_clasts_86.FIN2 & 91.3 & 0.85 & 3.327 & 0.064 & 0.2625 & 0.0036 & 0.466 & 1485 & 15 & 1501 & 18 & 1462 & 34 & 1462.0 & 34.0 & 27 & Single Age \\
\hline 19NB01_clasts_88.FIN2 & 909 & 2.07 & 0.0898 & 0.003 & 0.01412 & 0.00023 & 0.201 & 87.2 & 2.8 & 90.4 & 1.4 & 35 & 64 & 90.4 & 1.4 & 3.7 & Rim \\
\hline 19NB01_clasts_93.FIN2 & 363 & 0.63 & 1.154 & 0.016 & 0.1296 & 0.0012 & 0.509 & 779.2 & 7.7 & 785.2 & 7 & 764 & 25 & 785.2 & 7,0 & 0.8 & Single Age \\
\hline ts_94.FIN2 & 133.6 & 1.57 & 4.694 & 0.057 & 0.3035 & 0.0026 & 0.341 & 1765 & 10 & 1708 & 13 & 1835 & 21 & 1835.0 & 21.0 & 6.9 & Core \\
\hline 19NB01_clasts_97.FIN2 & 98.1 & 1.40 & 3.283 & 0.045 & 0.2596 & 0.0027 & 0.480 & 1475 & 11 & 1487 & 14 & 1460 & 25 & 1460.0 & 25.0 & 1.8 & Single Age \\
\hline 19NB01_clasts_106.FIN2 & 157.5 & 1.11 & 2.268 & 0.035 & 0.2054 & 0.0021 & 0.317 & 1201 & 11 & 1204 & 11 & 1190 & 31 & 1190.0 & 31.0 & 1.2 & Single Age \\
\hline 19NB01_clasts_114.FIN2 & 220 & 1.20 & 4.23 & 0.13 & 0.2853 & 0.0075 & 0.884 & 1675 & 26 & 1617 & 38 & 1746 & 28 & 1746.0 & 28.0 & 7.4 & Single Age \\
\hline 19NB01_clasts_118.FIN2 & 98 & 0.85 & 2.342 & 0.042 & 0.2116 & 0.0021 & 0.416 & 1222 & 13 & 1237 & 11 & 1189 & 33 & 1189.0 & 33.0 & 4.0 & Single Age \\
\hline 19NB01_clasts_120.FIN2 & 64.7 & 1.37 & 2.978 & 0.049 & 0.2418 & 0.0025 & 0.367 & 1399 & 13 & 1396 & 13 & 1410 & 32 & 1410.0 & 32.0 & 1.0 & Single Age \\
\hline 19NB01_clasts_124.FIN2 & 165.2 & 1.28 & 4.809 & 0.086 & 0.3236 & 0.0052 & 0.815 & 1784 & 15 & 1806 & 26 & 1753 & 19 & 1753.0 & 19.0 & 3.0 & Single Age \\
\hline \multicolumn{18}{|l|}{ per Nova } \\
\hline & 2 & & 147 & 0.079 & 0.3269 & 0.003 & 11 & 1841 & 13 & 823 & 15 & 1859 & 25 & 859.0 & 25.0 & 1.9 & ge \\
\hline
\end{tabular}




\begin{tabular}{|c|c|c|c|c|c|c|c|c|c|c|c|c|c|c|c|c|c|}
\hline \multirow{2}{*}{$\begin{array}{l}\text { Sample Name: } \\
\text { Grain \# }\end{array}$} & \multirow[b]{2}{*}[\mathrm{U}]{$\mathrm{ppm}$} & \multirow[b]{2}{*}{$\mathrm{U} / \mathrm{Th}$} & \multirow[b]{2}{*}{$207 / 235$} & \multirow[b]{2}{*}{$2 \sigma$} & \multirow[b]{2}{*}{$206 / 238$} & \multirow[b]{2}{*}{$2 \sigma$} & \multicolumn{3}{|c|}{$207 / 235$} & \multicolumn{2}{|l|}{$206 / 238$} & \multicolumn{2}{|l|}{$207 / 206$} & \multirow{2}{*}{$\begin{array}{c}\text { Best age } \\
\text { (Ma) }\end{array}$} & \multicolumn{2}{|c|}{ Disc. } & \multirow[b]{2}{*}{ Rim or Core } \\
\hline & & & & & & & RHO & Age (Ma) & $2 \sigma$ & Age (Ma) & $2 \sigma$ & Age (Ma) & $2 \sigma$ & & $2 \sigma$ & $\%$ & \\
\hline 19NB01_matrix_4.FIN2 & 147 & 0.95 & 11.3 & 0.14 & 0.4633 & 0.0056 & 0.767 & 2546 & 12 & 2453 & 25 & 2616 & 13 & 2616.0 & 13.0 & 6.2 & Single Age \\
\hline 19NB01_matrix_9.FIN2 & 108.1 & 0.88 & 3.041 & 0.04 & 0.2436 & 0.0019 & 0.394 & 1416 & 10 & 1405 & 10 & 1424 & 25 & 424.0 & 25.0 & 1.3 & Single Age \\
\hline 19NB01_matrix_10.FIN2 & 64 & 0.96 & 3.262 & 0.087 & 0.2517 & 0.0041 & 0.264 & 1469 & 21 & 1447 & 21 & 1486 & 52 & 1486.0 & 52.0 & 26 & Single Age \\
\hline 19NB01_matrix_17.FIN2 & 446 & 1.18 & 0.0964 & 0.0032 & 0.01384 & 0.00015 & 0.140 & 93.2 & 3 & 88.62 & 0.95 & 195 & 68 & 88.6 & 1.0 & 4.9 & Single Age \\
\hline 19NB01_matrix_22.FIN2 & 107.7 & 0.79 & 15.11 & 0.14 & 0.5386 & 0.004 & 0.643 & 2822.2 & 8.5 & 2777 & 17 & 2853 & 12 & 2853.0 & 12.0 & 2.7 & Single Age \\
\hline 19NB01_matrix_27.FIN2 & 91.5 & 0.85 & 2.259 & 0.043 & 0.2032 & 0.002 & 0.572 & 1196 & 14 & 1194 & 11 & 1209 & 31 & 1209.0 & 31.0 & 1.2 & Single Age \\
\hline 19NB01_matrix_33.FIN2 & 354 & 1.80 & 0.00308 & 0.00063 & 0.000467 & 0.000031 & 0.021 & 3.12 & 0.64 & 3.01 & 0.2 & -40 & 320 & 3.0 & 0.2 & 3.5 & Single Age \\
\hline 19NB01_matrix_35.FIN2 & 129 & 1.33 & 5.219 & 0.065 & 0.3354 & 0.0031 & 0.544 & 1855 & 11 & 1864 & 15 & 1832 & 20 & 1832.0 & 20.0 & 1.7 & Single Age \\
\hline 19NB01_matrix_62.FIN2 & 1340 & 7.50 & 0.244 & 0.024 & 0.0331 & 0.0022 & 0.806 & 221 & 19 & 210 & 14 & 340 & 120 & 210.0 & 14.0 & 5.0 & Rim \\
\hline 19NB01_matrix_62.FIN2 & 92 & 1.44 & 2.09 & 0.036 & 0.1926 & 0.0019 & 0.399 & 1145 & 12 & 1135 & 10 & 1169 & 32 & 1169.0 & 32.0 & 2.9 & Core \\
\hline \multicolumn{18}{|c|}{ Middle Nova Formation Coarse Fraction } \\
\hline 19NB02_clasts_1.FIN2 & 99.7 & 1.99 & 13.4 & 0.12 & 0.5207 & 0.0043 & 0.672 & 2706.9 & 8.7 & 2701 & 18 & 2711 & 12 & 2711.0 & 12.0 & 0.4 & Single Age \\
\hline 19NB02_clasts_2FIN2 & 158.5 & 0.78 & 11.2 & 0.14 & 0.4897 & 0.0044 & 0.705 & 2538 & 11 & 68 & 19 & 2511 & 15 & 511.0 & 15.0 & 2.3 & Single Age \\
\hline 19NB02_clasts_3.FIN2 & 1085 & 0.29 & 1.188 & 0.047 & 0.1205 & 0.004 & 0.668 & 794 & 21 & 3 & 23 & 70 & 61 & 733.0 & 23.0 & 7.7 & Rim \\
\hline 19NB02_clasts_4.FIN2 & 299.2 & 2.05 & 4.468 & 0.044 & 0.3063 & 0.0023 & 0.580 & 1723.8 & 8.2 & 1724 & 11 & 1721 & 15 & 1721.0 & 15.0 & 0.2 & Single Age \\
\hline 19NB02_clasts_5.FIN2 & 150.4 & 1.67 & 1.905 & 0.026 & 0.1832 & 0.0018 & 0.310 & 1081.3 & 9.2 & 1084.3 & 9.7 & 1070 & 27 & 1070.0 & 27.0 & 1.3 & Single Age \\
\hline 19NB02_clasts_6.FIN2 & 120.5 & 1.86 & 2.868 & 0.043 & 0.2363 & 0.0024 & 0.431 & 1371 & 11 & 1367 & 12 & 1369 & 27 & 1369.0 & 27.0 & 0.1 & Single Age \\
\hline $19 \mathrm{NB} 02$ c & 203 & 0.66 & 3.783 & 0.052 & 0.2702 & 0.0033 & 0.581 & 1587 & 11 & 1541 & 17 & 1655 & 16 & 1655.0 & 16.0 & 6.9 & Single Age \\
\hline 19NB02_c & 88.8 & 1.17 & 2.098 & 0.034 & 0.1965 & 0.0019 & 0.295 & 1146 & 11 & 1156 & 10 & 1119 & 33 & 1119.0 & 33.0 & 3.3 & Single Age \\
\hline $19 \mathrm{NB} 02$ cl & 408 & 1.36 & 2.271 & 0.02 & 0. & 0.002 & 0.556 & 1202.1 & 8.3 & 1223 & 11 & 1166 & 19 & 1166.0 & 19.0 & 4.9 & Single Age \\
\hline 19NB02_clas & 84.7 & 0.64 & 12 & & 0.5183 & 0.0069 & 0.781 & 2669 & 13 & 2694 & 29 & 2645 & 16 & 2645.0 & 16.0 & 1.9 & Single Age \\
\hline 19NB02_clasts_11.FIN2 & 299 & 1.46 & & 0.039 & & 0.0022 & 0.662 & 1626.9 & 8.1 & 1647 & 11 & 1603 & 14 & 1603.0 & 14.0 & 2.7 & Single Age \\
\hline $19 \mathrm{NB} 02$ clasts_12.FIN2 & 196.6 & 0.86 & 2.081 & 0.033 & 0.1885 & 0.0022 & 0.462 & 1141 & 11 & 1113 & 12 & 1193 & 27 & 1193.0 & 27.0 & 6.7 & Single Age \\
\hline $19 \mathrm{NB} 02$ clasts_13.FIN2 & 69 & 2.12 & 17.65 & 0.18 & 0.5863 & 0.0051 & 0.619 & 2968.9 & 9.6 & 2976 & 21 & 2967 & 14 & 2967.0 & 14.0 & 0.3 & Single Age \\
\hline 19NB02_clasts_14.FIN2 & 296.2 & 2.17 & 4.109 & 0.045 & 0.2872 & 0.003 & 0.705 & 1654.6 & 9 & 1627 & 15 & 1691 & 16 & 1691.0 & 16.0 & 3.8 & Single Age \\
\hline 19NB02_clasts_15.FIN2 & 43.13 & 1.00 & 16.05 & . & 0.5431 & 0.0095 & 0.599 & 2877 & 18 & 2794 & 40 & 2930 & 27 & 2930.0 & 27.0 & 4.6 & Single Age \\
\hline 19NB02_clasts_16.FIN2 & 143 & 0.85 & 3.994 & 0.076 & 0.2903 & 0.004 & 0.549 & 1633 & 15 & 1642 & 20 & 1615 & 31 & 1615.0 & 31.0 & 1.7 & Single Age \\
\hline 19NB02_clasts_20.FIN2 & 249 & 1.46 & 4.333 & 0.045 & 0.3066 & 0.0025 & 0.395 & 1698.3 & 8.7 & 1723 & 12 & 1669 & 19 & 1669.0 & 19.0 & 3.2 & Single Age \\
\hline 19NB02_clasts_21.FIN2 & 227.8 & 0.33 & 3.087 & 0.041 & 0.2442 & 0.0025 & 0.603 & 1428 & 10 & 1410 & 13 & 1455 & 20 & 1455.0 & 20.0 & 3.1 & Single Age \\
\hline 19NB02_clasts_24.FIN2 & 262.8 & 1.41 & 4.586 & 0.046 & 0.3102 & 0.003 & 0.791 & 1745.8 & 8.3 & 1741 & 15 & 1759 & 15 & 1759.0 & 15.0 & 1.0 & Single Age \\
\hline 19NB02_clasts_25.FIN2 & 134.2 & 0.84 & 3.998 & 0.052 & 0.291 & 0.003 & 0.457 & 1632 & 11 & 1646 & 15 & 1618 & 24 & 1618.0 & 24.0 & 1.7 & Single Age \\
\hline
\end{tabular}




\begin{tabular}{|c|c|c|c|c|c|c|c|c|c|c|c|c|c|c|c|c|c|}
\hline \multirow{2}{*}{$\begin{array}{l}\text { Sample Name: } \\
\text { Grain \# }\end{array}$} & \multirow[b]{2}{*}[\mathrm{U}]{$\mathrm{ppm}$} & \multirow[b]{2}{*}{ U/Th } & \multirow[b]{2}{*}{$207 / 235$} & \multirow[b]{2}{*}{$2 \sigma$} & \multirow[b]{2}{*}{$206 / 238$} & \multirow[b]{2}{*}{$2 \sigma$} & \multirow[b]{2}{*}{ RHO } & \multicolumn{2}{|l|}{$207 / 235$} & \multicolumn{2}{|l|}{$206 / 238$} & \multicolumn{2}{|l|}{$207 / 206$} & \multirow{2}{*}{$\begin{array}{c}\text { Best age } \\
\text { (Ma) }\end{array}$} & \multicolumn{2}{|c|}{ Disc. } & \multirow[b]{2}{*}{ Rim or Core } \\
\hline & & & & & & & & Age (Ma) & $2 \sigma$ & Age (Ma) & $2 \sigma$ & Age (Ma) & $2 \sigma$ & & $2 \sigma$ & $\%$ & \\
\hline 19NB02_clasts_26.FIN2 & 77.4 & 2.04 & 2.712 & 0.061 & 0.2334 & 0.0029 & 0.069 & 1328 & 17 & 1352 & 15 & 1291 & 40 & 1291.0 & 40.0 & 4.7 & Single Age \\
\hline NBB2_clasts_28.FIN2 & 30.6 & 1.01 & 2.287 & 0.058 & 2061 & 0.0026 & 0.149 & 1202 & 18 & 12 & 14 & 1186 & 54 & 186.0 & 5.0 & 1.8 & Single Age \\
\hline NB02_clasts_30.FIN2 & 160.6 & 0.67 & 3.8 & 0.068 & 2787 & 0.0043 & 0.685 & 1590 & 14 & 1584 & 22 & 1604 & 25 & 604.0 & 25.0 & 1.2 & Single Age \\
\hline NBD2_clasts_31.FIN2 & 219 & 2.09 & 2.861 & 0.049 & 2381 & 0.0037 & 0.701 & 1368 & 13 & 1376 & 19 & 1367 & 24 & 1367.0 & 24.0 & 0.7 & Single Age \\
\hline 19NB02_clasts_32.FIN2 & 141 & 1.33 & 3.287 & 0.042 & 2619 & 0.0028 & 0.420 & 1476 & 10 & 1499 & 14 & 1446 & 25 & 446.0 & 25.0 & 3.7 & Single Age \\
\hline 19NB02_clasts_33.FIN2 & 307 & 1.41 & 4.557 & 0.051 & 3124 & 0.0027 & 0.512 & 1740.4 & 9.4 & 1752 & 13 & 1732 & 17 & 732.0 & 17.0 & 1.2 & Single Age \\
\hline 19NB02_clasts_34.FIN2 & 479 & 3.43 & 4.309 & 0.035 & 04 & 0.0026 & 0.587 & 1694.4 & 6.8 & 1711 & 13 & 1679 & 13 & 679.0 & 13.0 & 1.9 & Single Age \\
\hline 19NB02_clasts_35.FIN2 & 159.3 & 1.15 & 2.528 & 0.034 & 0.2224 & 0.0018 & 0.238 & 1278.4 & 9.7 & 1294.1 & 9.3 & 1245 & 26 & 245.0 & 26.0 & 3.9 & Single Age \\
\hline 19NB02_clasts_36.FIN2 & 165 & 1.62 & 5.04 & 0.1 & 0.328 & 0.0061 & 0.755 & 1823 & 17 & 1834 & 30 & 1818 & 26 & 1818.0 & 26.0 & 0.9 & Single Age \\
\hline 19NB02_clasts_37.FIN2 & 186.9 & 2.87 & 4.771 & 0.055 & 0.3175 & 0.0024 & 0.511 & 1779.3 & 9.5 & 1777 & 12 & 1777 & 18 & 1777.0 & 18.0 & 0.0 & Single Age \\
\hline 19NB02_clasts_38.FIN2 & 420 & 3.86 & 4.959 & 0.055 & 0.3314 & 0.0029 & 0.729 & 1811.7 & 9.8 & 1845 & 14 & 1774 & 14 & 1774.0 & 14.0 & 4.0 & Single Age \\
\hline 19NB02_clasts_39.FIN2 & 52.2 & 1.18 & 1.989 & 0.044 & 0.1889 & 0.0022 & 0.107 & 1107 & 15 & 1116 & 12 & 1072 & 48 & 1072.0 & 48.0 & 4.1 & Single Age \\
\hline 19NB02_clasts_41.FIN2 & 852 & 10.50 & 4.44 & 0. & 0.308 & 0.016 & 0.624 & 1718 & 27 & 29 & 79 & 1703 & 70 & 1703.0 & 70.0 & 1.5 & Rim \\
\hline 19NB02_clasts_41.FIN2 & 382 & 0.87 & 12.84 & 14 & 6226 & 0.0048 & 0.757 & 2666 & 10 & 2709 & 20 & 2627 & 12 & 26 & 12.0 & 3.1 & Core \\
\hline 19NB02_clasts_42.FIN2 & 46.1 & 1.50 & 2.525 & 0.057 & 2193 & 0.0027 & 0.129 & 1274 & 17 & 1277 & 14 & 1250 & 49 & 250.0 & 49.0 & 2.2 & Single Age \\
\hline 19NB02_clasts_43.FIN2 & 567 & 2.41 & 3. & 0.15 & 2615 & 0.0086 & 0.771 & 1566 & 34 & 1497 & 44 & 1655 & 48 & 655.0 & 48.0 & 9.5 & le Age \\
\hline 19NB02_clasts_44.FIN2 & 521 & 2.22 & 4.142 & 0.088 & 0.2906 & 0.0059 & 0.849 & 1657 & 17 & 1642 & 29 & 1671 & 21 & 671.0 & 21.0 & 1.7 & Single Age \\
\hline 19NB02_clasts_45.FIN2 & 155.2 & 1.69 & 3.299 & 0.042 & 2595 & 0.0022 & 0.442 & 1479 & 10 & 1487 & 11 & 1455 & 23 & 455.0 & 23.0 & 2.2 & Single Age \\
\hline 19NB02_clasts_46.FIN2 & 154.8 & 0.53 & 2.297 & 0.045 & 2059 & 0.0033 & 0.557 & 1210 & 14 & 1206 & 17 & 1223 & 34 & 1223.0 & 34.0 & 1.4 & Single Age \\
\hline 19NB02_clasts_48.FIN2 & 126.1 & 0.55 & 3.109 & 0.044 & 0.2506 & 0.0029 & 0.415 & 1433 & 11 & 1441 & 15 & 1414 & 27 & 1414.0 & 27.0 & 1.9 & Single Age \\
\hline 19NB02_clasts_49.FIN2 & 217.2 & 29.40 & 13.42 & 0.2 & 0.5208 & 0.0076 & 0.700 & 2708 & 14 & 2702 & 32 & 2699 & 21 & 2699.0 & 21.0 & 0.1 & Single Age \\
\hline 19NB02_clasts_50.FIN2 & 81.1 & 0.71 & 3.25 & 0.053 & 0.2606 & 0.0029 & 0.319 & 1466 & 13 & 1492 & 15 & 1423 & 32 & 1423.0 & 32.0 & 4.8 & Single Age \\
\hline 19NB02_clasts_52.FIN2 & 300 & 0.83 & 102 & 0.025 & 0.1955 & 0.0015 & 0.373 & 1148.1 & 8.4 & 1150.8 & 83 & 1138 & 22 & 1138.0 & 22.0 & 1.1 & Single Age \\
\hline 19NB02_clasts_53.FIN2 & 619 & 51.00 & 1.7 & 0.034 & 0.1703 & 0.0027 & 0.000 & 1013 & 13 & 1013 & 15 & 1008 & 50 & 1008.0 & 50.0 & 0.5 & Rim \\
\hline 19NB02_clasts_53.FIN2 & 58.9 & 1.05 & 3.38 & 0.072 & 0.269 & 0.0035 & 0.269 & 1497 & 17 & 1535 & 18 & 1438 & 43 & 1438.0 & 43.0 & 6.7 & Core \\
\hline ts_54.FIN2 & 104.6 & 0.49 & 2.96 & 0.051 & 0.2366 & 0.0023 & 0.316 & 1395 & 13 & 1369 & 12 & 1424 & 31 & 1424.0 & 31.0 & 3.9 & Single Age \\
\hline 19NB02_clasts_55.FIN2 & 295 & 2.73 & 3.32 & 0.041 & 0.2592 & 0.0032 & 0.459 & 1486 & 9.9 & 1487 & 16 & 1483 & 25 & 1483.0 & 25.0 & 0.3 & Single Age \\
\hline 19NB02_clasts_56.FIN2 & 105.6 & 0.73 & 3.725 & 0.059 & 0.2677 & 0.0037 & 0.538 & 1574 & 13 & 1528 & 19 & 1640 & 27 & 640.0 & 27.0 & 6.8 & Single Age \\
\hline 19NB02_clasts_57.FIN2 & 147.9 & 1.34 & 4.74 & 0.12 & 0.3084 & 0.0054 & 0.716 & 1773 & 22 & 1733 & 26 & 1817 & 34 & 817.0 & 4.0 & 4.6 & Core \\
\hline 19NB02_clasts_58.FIN2 & 153.6 & 0.87 & 4.152 & 0.046 & 0.2959 & 0.0024 & 0.662 & 1664.5 & 9.3 & 1670 & 12 & 1653 & 19 & 653.0 & 19.0 & 1.0 & Single Age \\
\hline 19NB02_clasts_59.FIN2 & 179.9 & 1.40 & 2.222 & 0.029 & 0.2053 & 0.002 & 0.291 & 1186.6 & 9 & 1204 & 10 & 1150 & 25 & 1150.0 & 25.0 & 4.7 & Single Age \\
\hline $19 \mathrm{NB} 02$ clasts $60 . \mathrm{FIN} 2$ & 171.6 & 2.25 & 4.564 & 0.049 & 0.3138 & 0.0025 & 0.602 & 1741.3 & 9 & 1759 & 12 & 1725 & 17 & 1725.0 & 17.0 & 2.0 & Single Age \\
\hline
\end{tabular}




\begin{tabular}{|c|c|c|c|c|c|c|c|c|c|c|c|c|c|c|c|c|c|}
\hline \multirow{2}{*}{ Sample Name: } & \multirow[b]{2}{*}[\mathrm{U}]{$\mathrm{ppm}$} & \multirow[b]{2}{*}{$\mathrm{U} / \mathrm{Th}$} & \multirow[b]{2}{*}{$207 / 235$} & \multirow[b]{2}{*}{$2 \sigma$} & \multirow[b]{2}{*}{$206 / 238$} & \multirow[b]{2}{*}{$2 \sigma$} & \multicolumn{3}{|c|}{$207 / 235$} & \multicolumn{2}{|l|}{$206 / 238$} & \multicolumn{2}{|l|}{207206} & \multirow{2}{*}{$\begin{array}{c}\text { Best age } \\
\text { (Ma) }\end{array}$} & \multicolumn{2}{|r|}{ Dise. } & \\
\hline & & & & & & & RHO & Age (Ma) & $2 \sigma$ & Age (Ma) & $2 \sigma$ & Age (Ma) & $2 \sigma$ & & $2 \sigma$ & $\%$ & Rim or Core \\
\hline 19NB02_clasts_61.FIN2 & 158.8 & 0.91 & 4.322 & 0.053 & 0.3037 & 0.0031 & 0.494 & 1696 & 10 & 1709 & 15 & 1689 & 21 & 1689.0 & 21.0 & 1.2 & Single Age \\
\hline 19NB02_clasts_62.FIN2 & 94.4 & 5.70 & 2.561 & 0.051 & 2241 & 0.0032 & 0.525 & 1288 & 15 & 1302 & 17 & 1273 & 33 & 273.0 & 3.0 & 2.3 & Single Age \\
\hline $9 \mathrm{NB} 02$ clasts $63 . \mathrm{FIN} 2$ & 85.3 & 1.52 & 3.23 & 0.047 & 2561 & 0.0029 & 0.144 & 1462 & 11 & 1469 & 15 & 1457 & 29 & 1457.0 & 9.0 & 0.8 & Single Age \\
\hline NNB02_clasts_64.FIN2 & 59.4 & 1.55 & 2.396 & 0.047 & 0.2165 & 0.0032 & 0.401 & 1240 & 14 & 1263 & 17 & 1203 & 39 & 1203.0 & 39.0 & 5.0 & Single Age \\
\hline 19NB02_clasts_65.FIN2 & 321 & 0.96 & 4.435 & 0.042 & 122 & 0.0026 & 0.647 & 1718.7 & 8 & 1752 & 13 & 1690 & 15 & 1690.0 & 15.0 & 3.7 & Single Age \\
\hline 19NB02_clasts_66.FIN2 & 106.8 & 1.58 & 1.756 & 0.032 & 1754 & 0.002 & 0.338 & 1027 & 12 & 1042 & 11 & 996 & 37 & 996.0 & 37.0 & 4.6 & Single Age \\
\hline 19NB02_clasts_67.FIN2 & 155.1 & 0.89 & 12.52 & 21 & 5045 & 0.0084 & 0.780 & 2640 & 16 & 2629 & 36 & 2657 & 18 & 657.0 & 8.0 & 1.1 & Single Age \\
\hline 19NB02_clasts_68.FIN2 & 163 & 0.99 & 1.999 & 0.031 & 1913 & 0.0021 & 0.548 & 1114 & 11 & 1128 & 11 & 1096 & 27 & 96.0 & 7.0 & 2.9 & Single Age \\
\hline $19 \mathrm{NB} 02$ clasts_69.FIN2 & 189.2 & 1.32 & 2.657 & 0.037 & 2253 & 0.0023 & 0.422 & 1315 & 10 & 1309 & 12 & 1337 & 25 & 337.0 & 5.0 & 2.1 & Single Age \\
\hline 19NB02_clasts_70.FIN2 & 156.8 & 2.16 & 4. & 0.12 & 3215 & 0.008 & 0.676 & 1797 & 20 & 1795 & 39 & 1810 & 34 & 1810.0 & 34.0 & 0.8 & Single Age \\
\hline 19NB02_clasts_71.FIN2 & 309 & 0.90 & 2.185 & 0.021 & 2033 & 0.0014 & 0.532 & 1176.4 & 6.6 & 1192.6 & 7.5 & 1151 & 18 & 1151.0 & 18.0 & 3.6 & Single Age \\
\hline 19NB02_clasts_72.FIN2 & 525 & 0.90 & 12.87 & 0.24 & 5052 & 0.0085 & 0.898 & 2668 & 18 & 2635 & 37 & 2703 & 14 & 2703.0 & 14.0 & 2.5 & Single Age \\
\hline 19NB02_clasts_73.FIN2 & 386 & 2.39 & 4.501 & 0.065 & 3071 & 0.0037 & 0.831 & 1731 & 12 & 26 & 18 & 1740 & 16 & 740.0 & 6.0 & 0.8 & Core \\
\hline $19 \mathrm{NB} 02$ clasts_74.FIN2 & 132 & 1.42 & 4.54 & 0.1 & 04 & 0.0057 & 0.484 & 1738 & 20 & 1740 & 28 & 1731 & 35 & .0 & 5.0 & 0.5 & Single Age \\
\hline $19 \mathrm{NB} 02$ clasts_75.FIN2 & 253.2 & 0.79 & 2.204 & 0.029 & 2009 & 0.0021 & 0.472 & 1181.1 & 9.3 & 1181 & 11 & 1183 & 25 & 183.0 & 25.0 & 0.2 & Sing \\
\hline 19NB02_clasts_76.FIN2 & 202.3 & 0.74 & 5.826 & 0.063 & 3576 & 0. & 0.562 & 1949.1 & 9.4 & 1970 & 16 & 1929 & 18 & 0 & 18.0 & 2.1 & Single Age \\
\hline 19NB02_clasts_77.FIN2 & 130 & 1.73 & 2.842 & 0.048 & 2378 & 0.0035 & 0.483 & 1367 & 13 & 1374 & 18 & 1349 & 33 & 0 & 33.0 & 1.9 & Single Age \\
\hline 19NB02_clasts_78.FIN2 & 107.8 & 1.58 & 3. & 0.044 & 64 & 0.0026 & 0.356 & 1484 & 10 & 1510 & 13 & 1449 & 25 & 449.0 & 5.0 & 4.2 & e Age \\
\hline 19NB02_clasts_79.FIN2 & 185 & 2.10 & 1.887 & 0.029 & 1812 & 0.0018 & 0.431 & 1075 & 10 & 1073.5 & 9.9 & 1070 & 29 & 070.0 & 9.0 & 0.3 & Single Age \\
\hline 19NB02_clasts_81.FIN2 & 120.5 & 0.77 & 12 & 0.15 & 4896 & 0.0047 & 0.609 & 2641 & 11 & 2568 & 20 & 2699 & 16 & 2699.0 & 6.0 & 4.9 & Single Age \\
\hline 19NB02_clasts_82.FIN2 & 221.3 & 0.49 & 3.121 & 0.038 & 2543 & 0.0025 & 0.599 & 1436.2 & 9.4 & 1460 & 13 & 1400 & 19 & 1400.0 & 19.0 & 4.3 & Single Age \\
\hline 19NB02_clasts_83.FIN2 & 313 & 3.09 & 2.032 & 0.035 & 0.1939 & 0.0031 & 0.489 & 1125 & 12 & 1142 & 17 & 1089 & 32 & 1089.0 & 32.0 & 4.9 & Single Age \\
\hline 19NB02_clasts_84.FIN2 & 273 & 0.96 & 2.868 & 0.034 & 0. & 0.0025 & 0.596 & 1372.1 & 8.8 & 1388 & 12 & 1356 & 21 & 1356.0 & 21.0 & 2.4 & Single Age \\
\hline $19 \mathrm{NB} 02$ _clasts_88.FIN2 & 226.9 & 1.65 & 5.686 & 0.06 & 0.3559 & 0.0041 & 0.534 & 1928.8 & 8.9 & 1962 & 19 & 1891 & 20 & 1891.0 & 20.0 & 3.8 & Single Age \\
\hline 19NB02_clasts_92.FIN2 & 570 & 1.75 & 10.4 & 0. & 0.4628 & 0.0083 & 0.797 & 2473 & 17 & 2449 & 37 & 2491 & 21 & 2491.0 & 21.0 & 1.7 & Single Age \\
\hline $19 \mathrm{NB} 02 \mathrm{cl}$ & 372 & 31.30 & & 0. & & & 0.506 & 1099 & 48 & 1136 & 85 & 1040 & 160 & 1040.0 & 160.0 & 9.2 & Core \\
\hline $19 \mathrm{NB} 02$ cl & 610 & 4.36 & 4.2 & 0.07 & 0 . & 0.0045 & 0.889 & 1677 & 14 & 1631 & 22 & 1736 & 14 & 1736.0 & 14.0 & 6.0 & Single Age \\
\hline 19NB02_clasts_95.FIN2 & 65.3 & 0.77 & 4.868 & 0.07 & 0 . & 0.0033 & 0.157 & 1796 & 12 & 1821 & 16 & 1768 & 28 & 1768.0 & 28.0 & 3.0 & Single Age \\
\hline 19NB02_clasts_98.FIN2 & 248 & 1.62 & 1.759 & 0.022 & 0.1702 & 0.0016 & 0.393 & 1029.1 & 8.2 & 1012.7 & 9 & 1071 & 26 & 071.0 & 6.0 & 5.4 & Single Age \\
\hline $19 \mathrm{NB} 02$ clasts_99.FIN2 & 21.47 & 0.94 & 267 & 0.1 & 0.2294 & 0.0046 & 0.550 & 1311 & 28 & 1330 & 24 & 1281 & 71 & 281.0 & 71.0 & 3.8 & Single Age \\
\hline $19 \mathrm{NB} 02$ clasts_ $100 . \mathrm{FIN} 2$ & 1170 & 25.10 & 1.576 & 0.055 & & 0. & 0.638 & 960 & 22 & 930 & 56 & 1030 & 100 & 030.0 & 100.0 & 9.7 & Rim \\
\hline $19 \mathrm{NB} 02$ clasts $100 . \mathrm{FIN} 2$ & 172.5 & 0.77 & 4.166 & 0.055 & 0.2893 & 0.0029 & 0.531 & 1666 & 11 & 1640 & 15 & 1696 & 22 & 1696.0 & 22.0 & 3.3 & Core \\
\hline
\end{tabular}




\begin{tabular}{|c|c|c|c|c|c|c|c|c|c|c|c|c|c|c|c|c|c|}
\hline \multirow{2}{*}{$\begin{array}{l}\text { Sample Name: } \\
\text { Grain \# }\end{array}$} & \multirow[b]{2}{*}[\mathrm{U}]{$\mathrm{ppm}$} & \multirow[b]{2}{*}{ U/Th } & \multirow[b]{2}{*}{$207 / 235$} & \multirow[b]{2}{*}{$2 \sigma$} & \multirow[b]{2}{*}{$206 / 238$} & \multirow[b]{2}{*}{$2 \sigma$} & \multirow[b]{2}{*}{ RHO } & \multicolumn{2}{|l|}{$207 / 235$} & \multicolumn{2}{|l|}{$206 / 238$} & \multicolumn{2}{|l|}{$207 / 206$} & \multirow{2}{*}{$\begin{array}{c}\text { Best age } \\
\text { (Ma) }\end{array}$} & \multicolumn{2}{|c|}{ Disc. } & \multirow[b]{2}{*}{ Rim or Core } \\
\hline & & & & & & & & Age (Ma) & $2 \sigma$ & Age (Ma) & $2 \sigma$ & Age (Ma) & $2 \sigma$ & & $2 \sigma$ & $\%$ & \\
\hline 19NB02_clasts_101.FIN2 & 136.4 & 1.17 & 12.62 & 0.16 & 0.5067 & 0.0062 & 0.586 & 2649 & 12 & 2641 & 27 & 2652 & 19 & 2652.0 & 19.0 & 0.4 & Single Age \\
\hline NBO2_clasts_102.FIN2 & 59.9 & 1.03 & 3.113 & 056 & 2469 & 0.0033 & 0.419 & 1432 & 14 & & 17 & 1449 & 34 & 49.0 & 34.0 & 1.9 & Single Age \\
\hline NB02_clasts_104.FIN2 & 309 & 1.56 & 5.053 & 059 & 3349 & 0.0036 & 0.446 & 1829 & 10 & 1861 & 17 & 1796 & 21 & 796.0 & 1.0 & 3.6 & Age \\
\hline NB02_clasts_106.FIN2 & 152.4 & 1.74 & 3.279 & 0.044 & 62 & 0.0022 & 0.418 & 1474 & 10 & 1500 & 11 & 1435 & 24 & 435.0 & 24.0 & 4.5 & Single Age \\
\hline 19NB02_clasts_107.FIN2 & 52.9 & 0.90 & 2.297 & 0.051 & 2088 & 0.0025 & 0.145 & 1209 & 16 & 1222 & 13 & 1183 & 47 & 183.0 & 47.0 & 3.3 & Single Age \\
\hline 19NB02_clasts_108.FIN2 & 160.7 & 1.09 & 5.342 & 0.063 & 346 & 0.0039 & 0.557 & 1874 & 10 & 1915 & 19 & 1826 & 20 & 826.0 & 20.0 & 4.9 & Single Age \\
\hline 19NB02_clasts_110.FIN2 & 58.4 & 1.03 & 4.673 & 0.099 & 3036 & 0.0039 & 0.292 & 1759 & 17 & 1709 & 20 & 1818 & 38 & 1818.0 & 38.0 & 6.0 & Single Age \\
\hline 19NB02_clasts_111.FIN2 & 398 & 1.35 & 1.75 & 0.044 & 17 & 0.0041 & 0.624 & 1026 & 16 & 1012 & 23 & 1060 & 44 & 060.0 & 44.0 & 4.5 & Rim \\
\hline 19NB02_clasts_111.FIN2 & 123.3 & 0.62 & 3.71 & 0.073 & 0.2703 & 0.0036 & 0.360 & 1571 & 16 & 1542 & 18 & 1609 & 36 & 1609.0 & 36.0 & 4.2 & Core \\
\hline 19NB02_clasts_112.FIN2 & 79.4 & 0.65 & 4.44 & 0.1 & 0.3102 & 0.0039 & 0.339 & 1718 & 19 & 1741 & 19 & 1685 & 42 & 1685.0 & 42.0 & 3.3 & Single Age \\
\hline 19NB02_clasts_113.FIN2 & 39.8 & 2.05 & 2.053 & 0.059 & 0.1892 & 0.0032 & 0.202 & 1128 & 20 & 1116 & 17 & 1150 & 59 & 1150.0 & 59.0 & 3.0 & Single Age \\
\hline 19NB02_clasts_114.FIN2 & 188.6 & 1.78 & 2.825 & 0.042 & 0.2393 & 0.0028 & 0.432 & 1360 & 11 & 1383 & 14 & 1324 & 27 & 1324.0 & 27.0 & 4.5 & Single Age \\
\hline 19NB02_clasts_1 & 324 & 2.91 & 3.096 & 0.056 & 2492 & 0 & .565 & 129 & 14 & 36 & 22 & 1418 & 31 & 1418.0 & 1.0 & 1.3 & Core \\
\hline 19NB02_clasts_116.FIN2 & 409 & 2.46 & 4.799 & 0.053 & 0.3235 & 0.003 & 0.766 & 1783.2 & 9.4 & 06 & 14 & 1754 & 14 & 1754.0 & 14.0 & 3.0 & Single Age \\
\hline 19NB02_clasts_117.FIN2 & 166 & 1.44 & 206 & 0.033 & 0.191 & 0.0017 & 0.324 & 1135 & 11 & 1126.7 & 9.3 & 1147 & 31 & 1147.0 & 1.0 & 1.8 & Single Age \\
\hline 19NB02_clasts_118.FIN2 & 368 & 1.13 & 2.031 & 0.02 & 1903 & 0.0016 & 0.486 & 1125.2 & 6.7 & 1122.8 & 8.8 & 1124 & 21 & 124.0 & 21.0 & 0.1 & le Age \\
\hline 19NB02_clasts_119.FIN2 & 280.9 & 1.88 & 3.021 & 0.054 & 2365 & 0.0041 & 0.640 & 1411 & 14 & 1370 & 22 & 1475 & 30 & 475.0 & 30.0 & 7.1 & Single Age \\
\hline 19NB02_clasts_120.FIN2 & 238 & 2.17 & 13.85 & 0.14 & 0.5422 & 0.006 & 0.567 & 2737.4 & 9.7 & 2794 & 24 & 2698 & 17 & 2698.0 & 17.0 & 3.6 & Single Age \\
\hline 19NB02_clasts_121.FIN2 & 188 & 0.69 & 2.985 & 0.04 & 2402 & 0.0023 & 0.596 & 1403 & 10 & 1387 & 12 & 1421 & 23 & 421.0 & 23.0 & 2.4 & Single Age \\
\hline 19NB02_clasts_122.FIN2 & 431.8 & 3.26 & 4.256 & 0.051 & 0.2937 & 0.0035 & 0.638 & 1684.7 & 9.9 & 1662 & 18 & 1701 & 17 & 1701.0 & 17.0 & 2.3 & Single Age \\
\hline 19NB02_clasts_123.FIN2 & 201.4 & 1.16 & 3.121 & 0.035 & 0.2469 & 0.0026 & 0.471 & 1436.5 & 8.7 & 14 & 13 & 1445 & 23 & 1445.0 & 23.0 & 1.6 & Single Age \\
\hline 19NB02_clasts_124.FIN2 & 297 & 0.86 & 3.022 & 0.044 & 0.2418 & 0.0023 & 0.550 & 1412 & 11 & 1396 & 12 & 1427 & 24 & 1427.0 & 24.0 & 2.2 & Single Age \\
\hline 19NB02_clasts_125.FIN2 & 651 & 0.89 & 3.655 & 0.047 & 0.2659 & 0.0032 & 0.872 & 1561 & 10 & 19 & 16 & 1606 & 11 & 1606.0 & 11.0 & 5.4 & Single Age \\
\hline 19NB02_clasts_126.FIN2 & 55.6 & 0.89 & 4.832 & 0.078 & 0.3228 & 0.0041 & 0.523 & 1788 & 13 & 1802 & 20 & 1756 & 29 & 1756.0 & 29.0 & 2.6 & Single Age \\
\hline 19NB02_clasts_12 & 316.7 & 1.32 & 4. & 0.045 & 106 & 0.0022 & 0.547 & 1734.7 & 8.5 & 14 & 11 & 1711 & 17 & 1711.0 & 17.0 & 1.9 & Single \\
\hline ts_129.FIN2 & 172.5 & 2.41 & 2.206 & 0.026 & 0.2029 & 0.0015 & 0.145 & 1181.7 & 8.3 & 1190.6 & 7.9 & 1146 & 26 & 1146.0 & 26.0 & 3.9 & Single Age \\
\hline ts__130.FIN2 & 83.9 & 1.03 & 2.007 & 0.039 & 0.1886 & 0.0 & 0.291 & 1115 & 13 & & 11 & 1097 & 38 & 097.0 & 38.0 & 1.5 & Single Age \\
\hline 19NB02_clasts_131.FIN2 & 140.2 & 0.57 & 4.029 & 0.052 & 0.2848 & 0.0025 & 0.446 & 1639 & 10 & 1615 & 12 & 1651 & 22 & 651.0 & 2.0 & 2.2 & Single Age \\
\hline 19NB02_clasts_132.FIN2 & 303.4 & 0.91 & 3.153 & 0.032 & 0.2492 & 0.0019 & 0.374 & 1444.5 & 7.7 & 1433.9 & 9.6 & 1449 & 18 & 449.0 & 18.0 & 1.0 & Single Age \\
\hline 19NB02_clasts_133.FIN2 & 571.3 & 3.09 & 4.396 & 0.042 & 0.3044 & 0.0027 & 0.683 & 1710.5 & 7.9 & 1713 & 13 & 1693 & 14 & 693.0 & 14.0 & 1.2 & Single Age \\
\hline 19NB02_clasts_13 & 62 & 1.15 & 13.74 & 0.15 & 0.4935 & 0.0048 & 0.534 & 2730 & 10 & 2584 & 21 & 2828 & 16 & 2828.0 & 16.0 & 8.6 & Single Age \\
\hline 19NB02 clasts_1 & 290 & 3.18 & 4.868 & 0.061 & 0.3217 & 0.0036 & 0.688 & 1797 & 11 & 1797 & 18 & 1787 & 18 & 1787.0 & 18.0 & 0.6 & Single Age \\
\hline
\end{tabular}




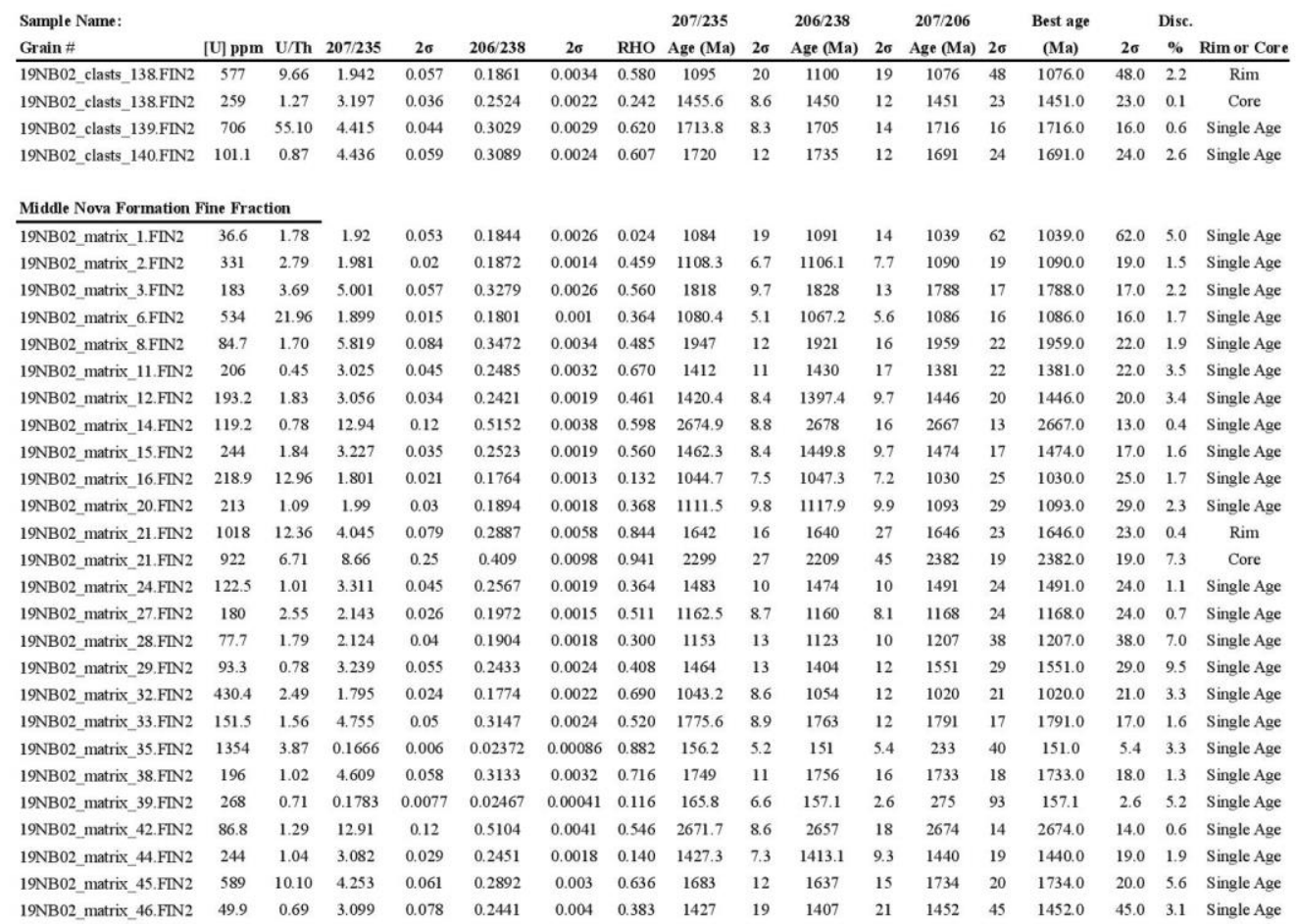




\begin{tabular}{|c|c|c|c|c|c|c|c|c|c|c|c|c|c|c|c|c|c|}
\hline \multirow{2}{*}{$\begin{array}{l}\text { Sample Name: } \\
\text { Grain \# }\end{array}$} & \multirow[b]{2}{*}[\mathrm{U}]{$\mathrm{ppm}$} & \multirow[b]{2}{*}{$\mathrm{U} / \mathrm{Th}$} & \multirow[b]{2}{*}{$207 / 235$} & \multirow[b]{2}{*}{$2 \sigma$} & \multirow[b]{2}{*}{$206 / 238$} & \multirow[b]{2}{*}{$2 \sigma$} & \multirow[b]{2}{*}{ RHO } & \multicolumn{2}{|l|}{$207 / 235$} & \multicolumn{2}{|l|}{$206 / 238$} & \multicolumn{2}{|l|}{ 207/206 } & \multirow{2}{*}{$\begin{array}{c}\text { Best age } \\
\text { (Ma) }\end{array}$} & \multicolumn{2}{|c|}{ Disc. } & \multirow[b]{2}{*}{ Rim or Core } \\
\hline & & & & & & & & Age (Ma) & $2 \sigma$ & Age (Ma) & $2 \sigma$ & Age (Ma) & $2 \sigma$ & & $2 \sigma$ & $\%$ & \\
\hline \multicolumn{18}{|c|}{ Lower Nova Formation Coarse Fraction } \\
\hline 19NB03_c_1.FIN2 & 265.6 & 2.55 & 10.42 & 0.22 & 0.4528 & 0.0098 & 0.934 & 2470 & 20 & 2407 & 44 & 2535 & 14 & 2535.0 & 14.0 & 5.0 & Single Age \\
\hline 19NB03_c_2FIN2 & 4.3 & 1.56 & 1.94 & 0.022 & 0.1855 & 0.0014 & 0.398 & 1094 & 7.5 & 1096.6 & 7.5 & 1096 & 24 & 096.0 & 24.0 & 0.1 & Single Age \\
\hline 19NB03_c_3.FIN2 & .8 & 1.42 & 1.903 & 0.035 & 0.1816 & 0.0017 & 0.292 & 1079 & 12 & 1075.5 & 9.1 & 1093 & 37 & 1093.0 & 37.0 & 1.6 & Single Age \\
\hline 19NB03_c_4.FIN2 & 93.1 & 1.26 & 1.997 & 0.039 & 0.1886 & 0.0028 & 0.490 & 1114 & 13 & 1115 & 16 & 1122 & 35 & 1122.0 & 35.0 & 0.6 & Single Age \\
\hline 19NB03_c_7.FIN2 & 110.9 & 1.43 & 4.206 & 0.065 & 0.2965 & 0.0031 & 0.402 & 1674 & 13 & 1673 & 15 & 1697 & 29 & 1697.0 & 29.0 & 1.4 & Single Age \\
\hline 19NB03_c_8FIN2 & 423.5 & 0.94 & 4.686 & 0.043 & 0.3091 & 0.0024 & 0.617 & 1763.7 & 7.7 & 1736 & 12 & 1809 & 13 & 1809.0 & 13.0 & 4.0 & Single Age \\
\hline 19NB03_c_9.FIN2 & 294 & 1.95 & 4.374 & 0.086 & 0.2909 & 0.0051 & 0.678 & 1704 & 17 & 1644 & 25 & 1798 & 28 & 1798.0 & 28.0 & 8.6 & Single Age \\
\hline 19NB03_c_10.FIN2 & 219.6 & 3.61 & 22.02 & 0.28 & 0.6369 & 0.0076 & 0.864 & 3183 & 12 & 3174 & 30 & 3206 & 12 & 3206.0 & 12.0 & 1.0 & Single Age \\
\hline 19NB03_c_11.FIN2 & 60.6 & 1.76 & 2.358 & 0.06 & 0.2028 & 0.0037 & 0.394 & 1224 & 18 & 1189 & 20 & 1299 & 49 & 1299.0 & 49.0 & 8.5 & Single Age \\
\hline 19NB03_c_12.FIN2 & 922 & 1.22 & 0.0048 & 0.0011 & 0.000738 & 0.000047 & 0.145 & 4.9 & 1.1 & 4.75 & 0.3 & 50 & 360 & 4.8 & 0.3 & 3.1 & Single Age \\
\hline 19NB03_c_14.FIN2 & 94.4 & 2.00 & 1.999 & 0.039 & 0.1884 & 0.0025 & 0.480 & 1112 & 13 & 1112 & 14 & 1127 & 35 & 1127.0 & 35.0 & 1.3 & Single Age \\
\hline 19NB03_c_16.FIN2 & 208.6 & 2.90 & 5.194 & 0.073 & 0.3393 & 0.0043 & 0.708 & 1851 & 12 & 1882 & 21 & 1831 & 19 & 1831.0 & 19.0 & 2.8 & Single Age \\
\hline 19NB03_c_17.FIN2 & 116.8 & 1.45 & 1.93 & 0.03 & 0.1868 & 0.0021 & 0.387 & 1089 & 10 & 1104 & 12 & 1077 & 31 & 1077.0 & 31.0 & 2.5 & Single Age \\
\hline NNB03_c_18.FIN2 & 69.4 & 0.75 & 1.644 & 0.046 & 0.1611 & 0.0032 & 0.504 & 981 & 18 & 962 & 18 & 1038 & 53 & 1038.0 & 53.0 & 7.3 & Single Age \\
\hline 19NB03_c_19.FIN2 & 1238 & 0.79 & 0.00432 & 0.0005 & 0.000651 & 0.000026 & 0.026 & 4.38 & 0.51 & 4.2 & 0.16 & 130 & 220 & 4.2 & 0.2 & 4.1 & Single Age \\
\hline 19NB03_c_20.FIN2 & 85.7 & 0.96 & 2.502 & 0.041 & 0.2137 & 0.0026 & 0.470 & 1272 & 12 & 1248 & 14 & 1326 & 30 & 1326.0 & 30.0 & 5.9 & Single Age \\
\hline 19NB03_c_22.FIN2 & 186.4 & 3.08 & 2.027 & 0.032 & 0.1918 & 0.0022 & 0.337 & 1122 & 11 & 1131 & 12 & 1126 & 33 & 1126.0 & 33.0 & 0.4 & Single Age \\
\hline 19NB03_c_23.FIN2 & 141.5 & 1.70 & 3.424 & 0.048 & 0.26 & 0.003 & 0.494 & 1508 & 11 & 1489 & 15 & 1542 & 25 & 1542.0 & 25.0 & 3.4 & Single Age \\
\hline 19NB03_c_26.FIN2 & 182.9 & 0.92 & 2.631 & 0.063 & 0.2273 & 0.0066 & 0.632 & 1305 & 18 & 1318 & 35 & 1304 & 45 & 1304.0 & 45.0 & 1.1 & Single Age \\
\hline 19NB03_c_27.FIN2 & 169.2 & 2.55 & 4.561 & 0.052 & 0.3064 & 0.0026 & 0.447 & 1740.5 & 9.5 & 1722 & 13 & 1774 & 20 & 1774.0 & 20.0 & 2.9 & Single Age \\
\hline 19NB03_c_28.FIN2 & 174.1 & 0.91 & 4.637 & 0.058 & 0.3047 & 0.0033 & 0.588 & 1755 & 11 & 1714 & 16 & 1814 & 20 & 1814.0 & 20.0 & 5.5 & Single Age \\
\hline 19NB03_c_2 & 201.7 & 0.51 & 8.65 & 0.1 & 0.4207 & 0.004 & 0.666 & 2302 & 11 & 2263 & 18 & 2341 & 15 & 2341.0 & 15.0 & 3.3 & Single Age \\
\hline 19NB03_c_3 & . & 1.53 & 1.841 & 0.027 & 0.1782 & 0.0017 & 0.498 & 1059.8 & 9.9 & 1056.6 & 9.4 & 1075 & 26 & 1075.0 & 26.0 & 1.7 & Single Age \\
\hline 19NB03_c_3 & 241.8 & 1.90 & 4.189 & 0.071 & 0.2883 & 0.0044 & 0.774 & 1670 & 14 & 1631 & 22 & 1724 & 21 & 1724.0 & 21.0 & 5.4 & Single Age \\
\hline 19NB03_c_3 & 206.1 & 1.68 & 5.977 & 0.074 & 0.3532 & 0.0037 & 0.739 & 1971 & 11 & 1949 & 18 & 2006 & 15 & 2006.0 & 15.0 & 2.8 & Single Age \\
\hline 19NB03_c_33.FIN2 & 221.4 & 2.03 & 2.401 & 0.028 & 0.2123 & 0.0018 & 0.488 & 1242.6 & 8.7 & 1240.7 & 9.3 & 1250 & 20 & 1250.0 & 20.0 & 0.7 & Single Age \\
\hline 19NB03_c_34.FIN2 & 307 & 1.98 & 4.158 & 0.068 & 0.2881 & 0.0043 & 0.678 & 1662 & 13 & 1631 & 21 & 1711 & 23 & 1711.0 & 23.0 & 4.7 & Single Age \\
\hline 19NB03_c_35.FIN2 & 297 & 5.28 & 4.748 & 0.065 & 0.3161 & 0.0041 & 0.732 & 1773 & 12 & 1769 & 20 & 1787 & 18 & 1787.0 & 18.0 & 1.0 & Single Age \\
\hline 19NB03_c_36.FIN2 & 240.1 & 1.93 & 2.961 & 0.036 & 0.2391 & 0.0023 & 0.554 & 1397.4 & 9.3 & 1382 & 12 & 1427 & 20 & 1427.0 & 20.0 & 3.2 & Single Age \\
\hline 19NB03_c & 255 & 1.44 & 2.404 & 0.04 & 0.2108 & 0.0027 & 0.583 & 1242 & 12 & 1233 & 14 & 1258 & 27 & 1258.0 & 27.0 & 20 & Single Age \\
\hline $19 \mathrm{NB} 03$ с $39 . \mathrm{FIN} 2$ & 150.5 & 2.28 & 4.455 & 0.084 & 0.302 & 0.004 & 0.638 & 1718 & 16 & 1700 & 20 & 1738 & 27 & 1738.0 & 27.0 & 2.2 & Single Age \\
\hline
\end{tabular}




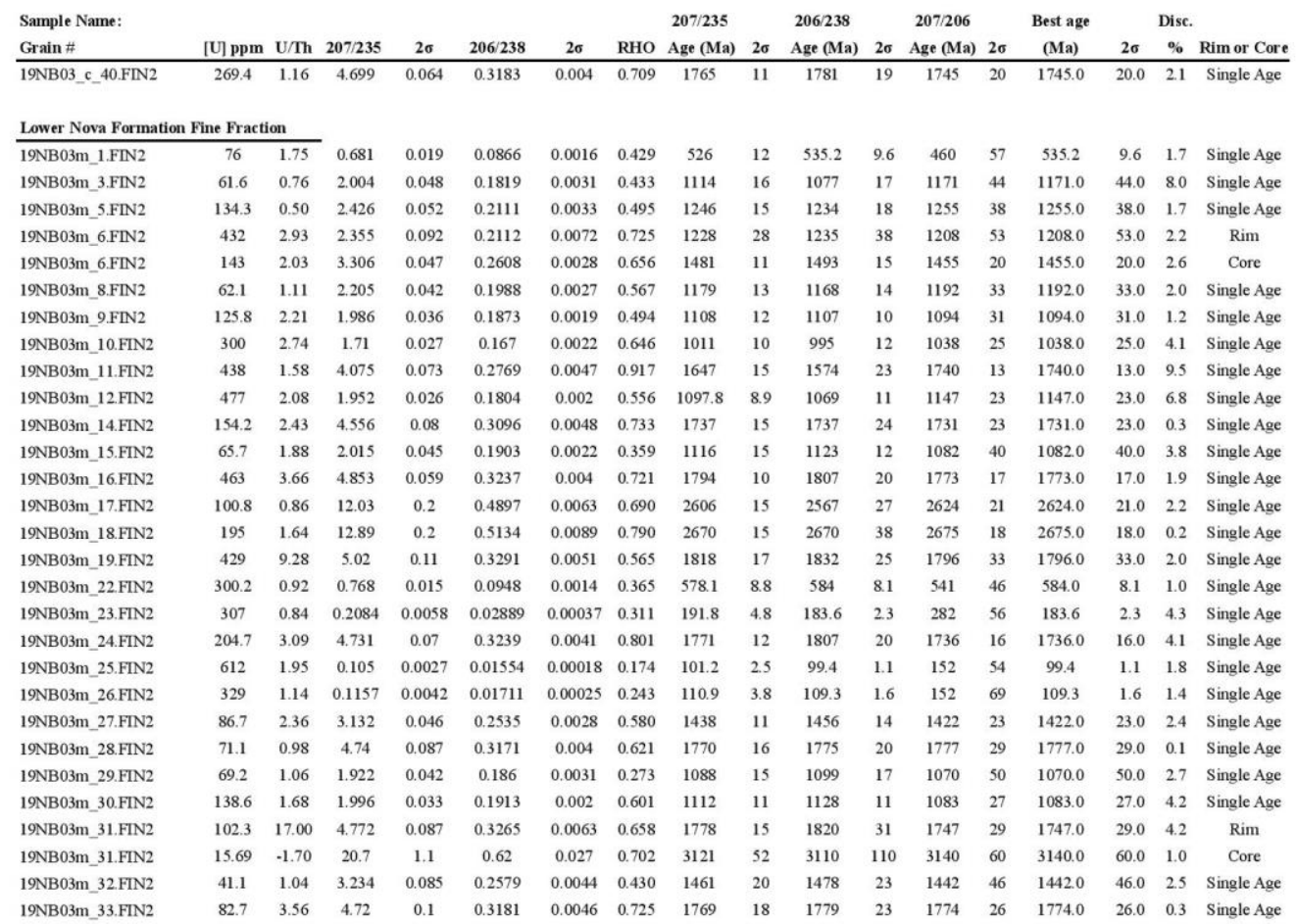




\begin{tabular}{|c|c|c|c|c|c|c|c|c|c|c|c|c|c|c|c|c|c|}
\hline $\mathrm{mpl}$ & & & & & & & & & & $206 / 2$ & & $207 / 206$ & & Best age & & Disc. & \\
\hline Grain \# & U] $\mathrm{ppm}$ & U/Th & $207 / 235$ & $2 \sigma$ & $206 / 238$ & $2 \sigma$ & RHO & Age (Ma) & $2 \sigma$ & Age (Ma) & $2 \sigma$ & Age (Ma) & $2 \sigma$ & (Ma) & $2 \sigma$ & $\%$ & Rim or Core \\
\hline 19NB03m_34.FIN2 & 308 & 1.12 & 9.96 & 0.28 & 0.433 & 0.01 & 0.909 & 2424 & 26 & 2316 & 47 & 2529 & 20 & 2529.0 & 20.0 & 8.4 & Single Age \\
\hline NB03m_36.FIN2 & 144 & 2.71 & 2.156 & 037 & 2023 & 0.0026 & 0.650 & 1164 & 12 & 1187 & 14 & 1139 & 27 & 139.0 & 7.0 & 4.2 & Single Age \\
\hline NBO3m_37.FIN2 & 82.8 & 1.06 & 2.005 & 0.047 & 89 & 0.0038 & 0.610 & 1114 & 16 & 1114 & 21 & 1125 & 40 & 125.0 & 40.0 & 1.0 & Single Age \\
\hline 19NB03m_38.FIN2 & 208 & 0.74 & 0.1115 & 0.0049 & 0.01641 & 0.00032 & 0.170 & 107 & 4.4 & 104.9 & 2.1 & 155 & 81 & 104.9 & 2.1 & 2.0 & Single Age \\
\hline 19NB03m_39.FIN2 & 845 & 1.45 & 0.0896 & 0.0035 & 0.01385 & 0.00039 & 0.422 & 87 & 3.2 & 88.7 & 2.5 & 79 & 74 & 88.7 & 2.5 & 2.0 & Single Age \\
\hline 19NB03m_40.FIN2 & 105.8 & 1.33 & 1.94 & 0.031 & 0.1884 & 0.002 & 0.552 & 1094 & 11 & 1112 & 11 & 1065 & 28 & 1065.0 & 28.0 & 4.4 & Single Age \\
\hline 19NB03m_41.FIN2 & 94.8 & 1.55 & 1.832 & 0.031 & 0.179 & 0.0025 & 0.532 & 1055 & 11 & 1061 & 13 & 1060 & 32 & 1060.0 & 32.0 & 0.1 & Single Age \\
\hline 19NB03m_42.FIN2 & 254.8 & 1.77 & 4.243 & 0.051 & 0.2982 & 0.0035 & 0.722 & 1680.7 & 9.9 & 1681 & 17 & 1680 & 17 & 1680.0 & 17.0 & 0.1 & Single Age \\
\hline 19NB03m_43.FIN2 & 69.7 & 1.73 & 5.203 & 0.06 & 0.3377 & 0.003 & 0.399 & 1851.4 & 9.9 & 1875 & 14 & 1832 & 21 & 1832.0 & 21.0 & 2.3 & Single Age \\
\hline 19NB03m_44.FIN2 & 41.5 & 1.15 & 2.474 & 0.061 & 0.2189 & 0.0038 & 0.443 & 1263 & 18 & 1275 & 20 & 1245 & 46 & 245.0 & 46.0 & 2.4 & Single Age \\
\hline NBB3m_45.FIN2 & 76.3 & 1.86 & 3.188 & 0.05 & 2563 & 0.0026 & 0.335 & 1451 & 12 & 70 & 13 & 1432 & 30 & 1432.0 & 30.0 & 2.7 & Single Age \\
\hline NBB03m_46.FIN2 & 54.8 & 1.77 & 5.281 & 0.082 & 0.3417 & 0.0036 & 0.559 & 1864 & 14 & 1897 & 18 & 1832 & 27 & 183 & 27.0 & 3.5 & Single Age \\
\hline 19NB03m_47.FIN2 & 103.6 & 1.03 & 0.1673 & 0.0098 & 0.02462 & 0.00048 & 0.026 & 156.1 & 8.5 & 156.8 & 3 & 160 & 120 & 156.8 & 3.0 & 0.4 & Single Age \\
\hline 19NB03m_48.FIN2 & 352 & 1.88 & 5.029 & 0.069 & 0.3316 & 0.0043 & 0.477 & 1822 & 12 & 1845 & 21 & 1802 & 26 & 1802.0 & 26.0 & 2.4 & Single Age \\
\hline 19NB03m_49.FIN2 & 294.1 & 1.68 & 3.998 & 0.048 & 0.2777 & 0.0036 & 0.751 & 1633.3 & 9.6 & 1579 & 18 & 1708 & 17 & 1708.0 & 17.0 & 7.6 & Single Age \\
\hline $19 \mathrm{NB} 03 \mathrm{~m} \_52$ FIN2 & 318.2 & 1.57 & 2.921 & 0.029 & 0.2404 & 0.002 & 0.634 & 1386.3 & 7.7 & 1389 & 11 & 1388 & 16 & 1388.0 & 16.0 & 0.1 & Single Age \\
\hline 19NB03m_53.FIN2 & 154 & 1.67 & 3.191 & 0.033 & 0.2592 & 0.0024 & 0.569 & 1453.8 & 7.9 & 1485 & 12 & 1418 & 18 & 1418.0 & 18.0 & 4.7 & Single Age \\
\hline 19NB03m_55.FIN2 & 379.3 & 42.20 & 5.213 & 0.049 & 0.3327 & 0.0027 & 0.678 & 1854.5 & 7.9 & 1851 & 13 & 1859 & 13 & 1859.0 & 13.0 & 0.4 & Single Age \\
\hline 19NB03m_58.FIN2 & 257.9 & 1.75 & 4.778 & 0.043 & 0.3211 & 0.0025 & 0.631 & 1780 & 7.6 & 1795 & 12 & 1769 & 13 & 1769.0 & 13.0 & 1.5 & Single Age \\
\hline 19NB03m_59.FIN2 & 29.88 & 1.31 & 1.975 & 0.059 & 0.1847 & 0.0031 & 0.421 & 1100 & 20 & 1092 & 17 & 1127 & 55 & 1127.0 & 55.0 & 3.1 & Single Age \\
\hline 19NB03m_60.FIN2 & 399 & 1.14 & 12.0 & 0. & 0.5157 & 0.0085 & 0.796 & 2603 & 13 & 2677 & 36 & 2554 & 17 & 2554.0 & 17.0 & 4.8 & Single Age \\
\hline 19NB03m_61 & 346 & 3.52 & 4.853 & 0.061 & & 0.0034 & 0.719 & 1792 & 11 & 1813 & 17 & 1768 & 17 & 1768.0 & 17.0 & 2.5 & Single Age \\
\hline 19NB03m_62.FIN2 & 422 & 2.24 & 4.293 & 0.044 & 0.2926 & 0.0028 & 0.559 & 1690.8 & 8.5 & 1654 & 14 & 1741 & 16 & 1741.0 & 16.0 & 5.0 & Single Age \\
\hline 19NB03m_63.FIN2 & 1591 & -10.00 & 1.359 & 0.052 & 0.1298 & 0.0036 & 0.418 & 871 & 22 & 787 & 21 & 1097 & 72 & 787.0 & 21.0 & 9.6 & Rim \\
\hline 19NB03m_63.FIN2 & 695 & 119.00 & 2.053 & 0.044 & 0.1952 & 0.0033 & 0.612 & 1132 & 14 & 1149 & 18 & 1105 & 35 & 1105.0 & 35.0 & 4.0 & Rim \\
\hline 19NB03m_63.FIN2 & 166.8 & 1.99 & 4.632 & 0.079 & 0.3213 & 0.0045 & 0.493 & 1753 & 14 & 1795 & 22 & 1709 & 30 & 1709.0 & 30.0 & 5.0 & Core \\
\hline 19NB03m 64.FIN2 & 92 & 0.64 & 13.53 & 0.13 & 0.5227 & 0.0045 & 0.581 & 2715.7 & 9.1 & 2709 & 19 & 2724 & 14 & 2724.0 & 14.0 & 0.6 & Single Age \\
\hline
\end{tabular}

